UNIVERSIDADE DE SÃO PAULO

FACULDADE DE FILOSOFIA, LETRAS E CIÊNCIAS HUMANAS

DEPARTAMENTO DE CIÊNCIA POLÍTICA

\title{
A força dos "partidos fracos" - um estudo sobre a organização dos partidos brasileiros e seu impacto na coordenação eleitoral
}

Fernando Henrique Eduardo Guarnieri

Tese de doutoramento apresentada ao Departamento de Ciência Política da Faculdade de Filosofia Letras e Ciências Humanas da Universidade de São Paulo, como exigência parcial para a obtenção do título de Doutor em Ciência Política.

Orientador: Prof. Dr. Fernando de Magalhães Papaterra Limongi

São Paulo, 2009 


\author{
UNIVERSIDADE DE SÃO PAULO \\ FACULDADE DE FILOSOFIA, LETRAS E CIÊNCIAS HUMANAS \\ DEPARTAMENTO DE CIÊNCIA POLÍTICA
}

\title{
A força dos "partidos fracos" - um estudo sobre a organização dos partidos brasileiros e seu impacto na coordenação eleitoral
}

Fernando Henrique Eduardo Guarnieri

Tese de doutoramento apresentada ao Departamento de Ciência Política da Faculdade de Filosofia Letras e Ciências Humanas da Universidade de São Paulo, como exigência parcial para a obtenção do título de Doutor em Ciência Política.

Orientador: Prof. Dr. Fernando de Magalhães Papaterra Limongi

São Paulo, 2009 
Esta tese foi defendida em ______ perante a seguinte banca examinadora:

Professor Orientador

Prof. Dr. Fernando Limongi 
Para minha mãe, Vanya, a primeira cientista que conheci e de quem herdei esse desejo da descoberta que move o mundo. 


\section{AGRADECIMENTOS}

Agradeço, antes de tudo, ao Prof. Limongi. Primeiro pela maneira amigável com que me acolheu no meu retorno à universidade. Depois pelo jeito Zen com que orientou este trabalho. O Prof. Limongi teve a capacidade de pinçar, nas minhas idéias abstratas, questões fundamentais que conduziram, como que por encanto, a descobertas surpreendentes, que espero ser capaz de expor nesta tese. Acima de tudo, o Prof. Limongi me fez entender o que é Ciência, o que é fazer Ciência e a desejar fazer cada vez mais. Agradeço também aos outros orientandos do Prof. Limongi, com quem pude compartilhar momentos de diálogo e aprendizado fundamentais para o desenvolvimento de vários pontos deste estudo. Agradeço especialmente aos colegas Andrea Freitas, Lara Mesquita e Rafael Cortez que me apoiaram com dados e com dicas de leitura.

Agradeço aos meus colegas do Seminário de Ciência Política, conduzido de maneira magistral pelo Prof. Gildo Marçal Brandão. Neste Seminário tive a oportunidade de receber críticas e sugestões ao meu projeto de pesquisa por parte do Prof. Claudio Couto da Fundação Getúlio Vargas e do próprio Prof. Gildo, além dos colegas de curso. Essas sugestões e críticas me ajudaram muito a desenvolver este trabalho final. Agradeço aos Professores Leandro Piquet e Matthew Taylor, que fizeram parte da banca de meu exame de qualificação. A partir de suas observações, minha pesquisa recebeu novo rumo e novo alento. 
Agradeço também aos Professores Eduardo Marques, Maria Hermínia e Marta Arretche, com quem tive o prazer de conviver em classe de aula e ao apoio prestado pela Secretaria de Pós-Graduação do Departamento de Ciência Política, especialmente à Rai e à Viviane.

Por fim, agradeço à minha mulher, Ana Célia, que compreendeu e apoiou minha dedicação a esta pesquisa, que a privou de minha companhia durante as longas horas de estudo.

Agradeço a meus filhos Mario e João, por me fazerem tantas perguntas. 


\section{TÍTULO}

A força dos "partidos fracos" - um estudo sobre a organização dos partidos brasileiros e seu impacto na coordenação eleitoral 


\section{RESUMO}

A presente pesquisa tem por objetivo preencher algumas lacunas nos estudos sobre a arena eleitoral brasileira. A literatura corrente, ao negligenciar o estudo da organização partidária, acaba por negligenciar questões fundamentais para que se entenda como funciona o processo eleitoral. Neste estudo iremos responder a três questões: Como os partidos brasileiros funcionam? O que explica o número de partidos em nosso sistema partidário? Qual o impacto da organização partidária na decisão de um partido de lançar ou não um candidato em determinada eleição?

Pretendemos mostrar que os partidos têm mais vida do que julga grande parte dos estudos sobre nosso sistema político. Essa vida partidária ajuda a entender melhor a coordenação eleitoral que, por sua vez, determina o número de partidos que participam de determinada eleição.

\section{PALAVRAS-CHAVE}

Partidos, organização partidária, coordenação eleitoral, Lei de Duverger, Modelos de Entrada. 


\begin{abstract}
The present research aims to bridge a gap in the studies of the Brazilian electoral arena. The current literature has neglected the study of party organizations and, for that reason, has neglected fundamental questions to understand how the electoral process works. In the present study we will try to answer to three questions: How do Brazilian parties work? What explains the number of parties in our party system? How does party organization impact on the decision of parties to enter or not the electoral contests?

We will show that parties have more "life" than is supposed by much of the studies about our political system. This party life helps us to better understand the electoral coordination, responsible for the actual number of parties in a given election.
\end{abstract}

\title{
KEYWORDS
}

Parties, party organization, electoral coordination, Duverger Law, Entry Models. 


\section{SUMÁRIO}

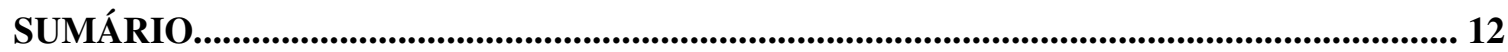

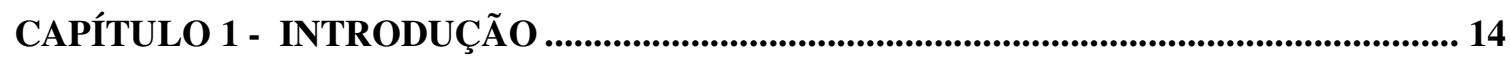

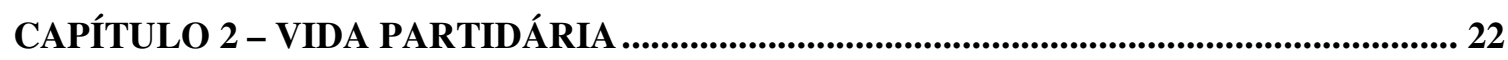

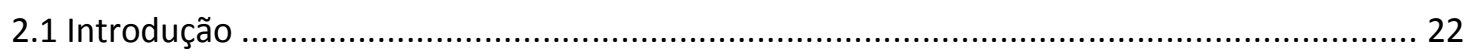

2.20 problema da "vida partidária" e a "fraqueza" dos partidos................................................ 25

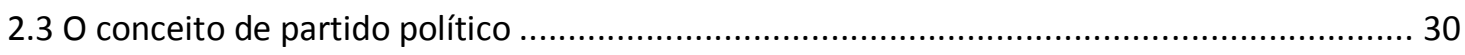

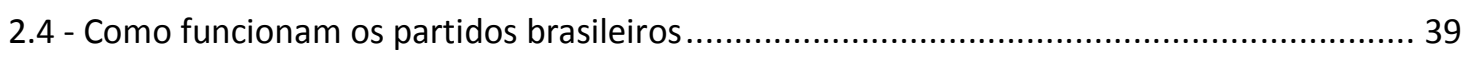

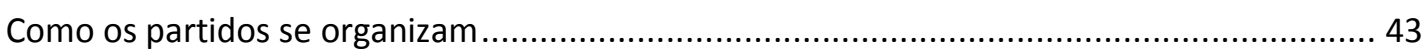

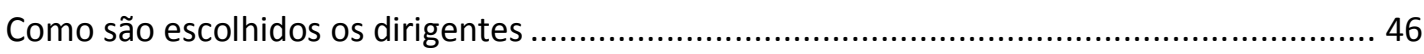

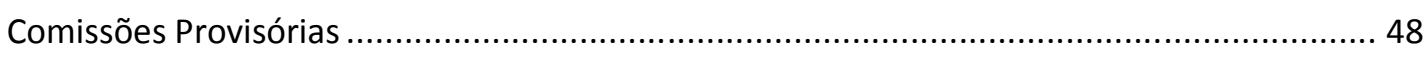

Uma tipologia das organizações partidárias brasileiras ......................................................... 52

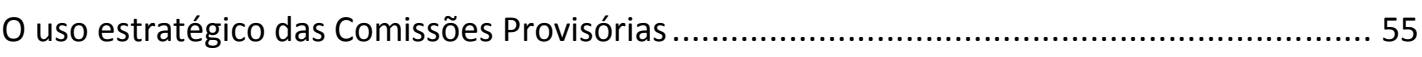

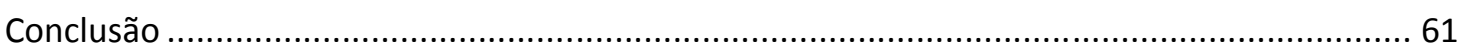

CAPÍTULO 3 - VOTO ESTRATÉGICO E COORDENAÇÃO ELEITORAL NO BRASIL 64

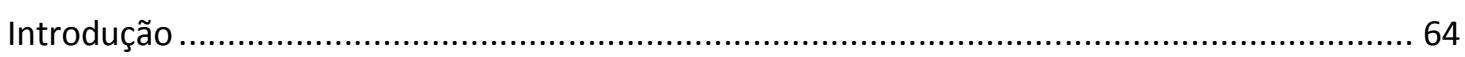

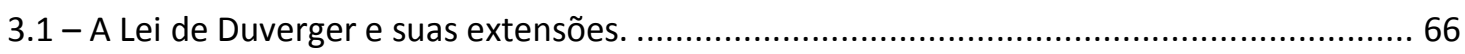

3.2 - Testando os efeitos da Lei de Duverger nas eleições majoritárias no Brasil........................ 78

Testando a Lei de Duverger nas eleições de um só turno para prefeito.................................... 79

Testando a Lei de Duverger nas eleições de dois turnos para governador de estado.............. 82

Testando a Lei de Duverger para as eleições para Presidência da República .......................... 91

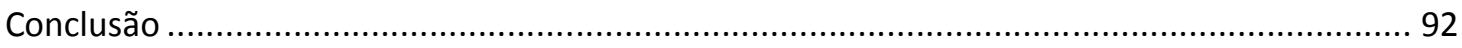

CAPÍTULO 4 - COORDENAÇÃo ELEITORAL E ORGANIZAÇÃO PARTIDÁRIA ....... 94

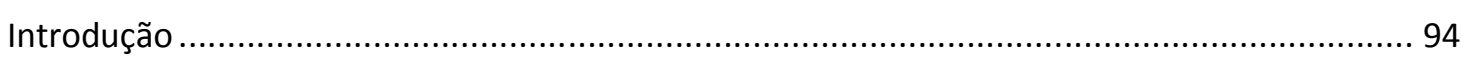

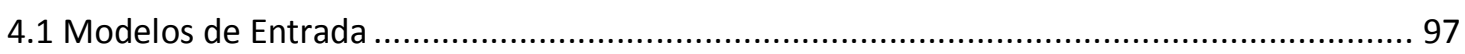

4.2 Testando os modelos de entrada nas eleições majoritárias ...............................................105

Testando os modelos de entrada nas eleições para o governo do estado .............................114

Testando os modelos de entrada nas eleições para prefeitura.............................................120

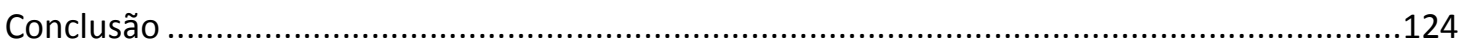


CAPÍTULO 5 - MODELOS ORGANIZATIVOS..................................................................131

Partidos Poliárquicos......................................................................................... 131

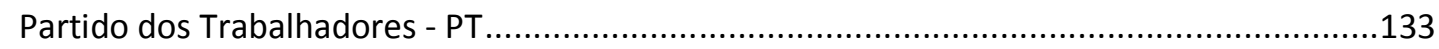

Partido do Movimento Democrático Brasileiro - PMDB .............................................141

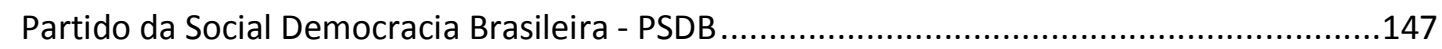

Partidos oligárquicos de organização mista ...............................................................153

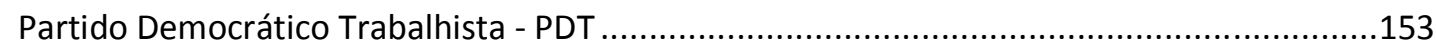

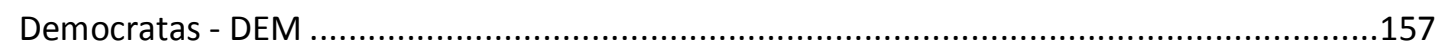

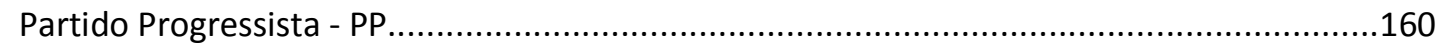

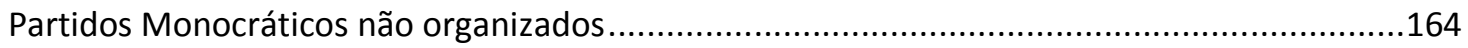

Partido Trabalhista Brasileiro - PTB................................................................... 164

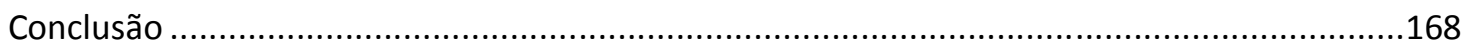

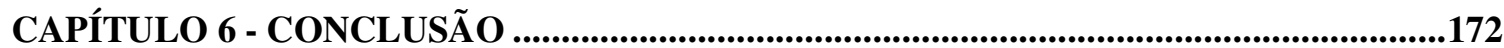

ANEXO 1 - Distribuição dos partidos conforme situação do órgão partidário municipal por

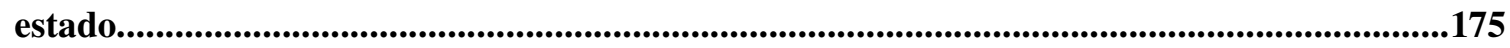

ANEXO 2 - Distribuição dos partidos conforme situação do órgão partidário regional por

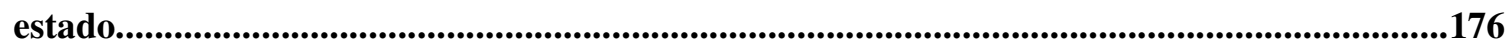

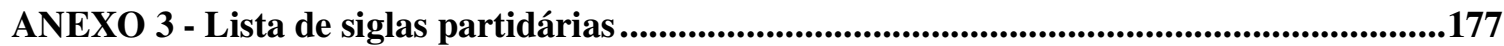

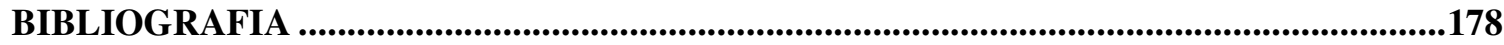




\section{SUMÁRIO}

Tabela 2.1 - Evolução do Fundo Partidário - 1994 a 2003 ............................................................ 41

Tabela 2.2 - Distribuição dos partidos conforme a situação do órgão partidário municipal ............ 50

Tabela 2.3 - Distribuição dos partidos conforme a proporção de comissões provisórias por estado 50

Tabela 2.4 - Distribuição dos partidos conforme a situação do órgão partidário regional............... 51

Tabela 2.5 - Classificação dos partidos conforme a proporção de comissões provisórias ............... 52

Tabela 2.6- Taxa de permanência de dirigentes partidários nos sete maiores partidos brasileiros.60

Tabela 3.1 - Número de candidatos nas disputas para governador do estado entre 1990 e 2006 . 83

Tabela 3.2- Número efetivo de candidatos nas disputas para governador do estado entre 1990 e 2006

Tabela 4.1 - Número de vezes que um partido decidiu se coligar nas eleições para prefeito, governador e presidente entre 1989 e 2008 106

Tabela 4.2 - Decisão de entrar na disputa para governador de estado conforme chance de vitória

Tabela 4.3 - Decisão de entrar na disputa para prefeito conforme chance de vitória 109

Tabela 4.4 - Média e variância das posições dos deputados federais dos principais partidos brasileiros nas 49a , 50a , 51a e 52 a legislaturas.

Tabela 4.5 - Coeficientes estimados, erros padrão, valores de $|z|$ e significância para o Modelo de Entrada para as eleições para o governo do estado. 115

Tabela 4.6 - Primeiras diferenças e razão de risco, com intervalo de confiança de 95\%, para a diferença na probabilidade de um partido sem chance lançar candidatos quando se passa de menos de $25 \%$ de diretórios em um estado para mais de $75 \%$

Tabela 4.7- - Coeficientes estimados, erros padrão, valores de $|z|$ e significância para o Modelo de Entrada para as eleições municipais.

Tabela 4.8 - Primeiras diferenças e razão de risco, com intervalo de confiança de 95\%, para a diferença na probabilidade de um partido sem chance lançar candidatos quando há a presença de Diretório e quando há Comissão Provisória. 
GRÁFICO 3.1 - Distribuição das eleições municipais conforme o número de candidatos que entraram na disputa.....

GRÁFICO 4.1 - Distribuição da probabilidade de lançar candidato conforme o grau de concentração partidária e pela chance de vitória..

GRÁFICO 4.2 - Curva ROC comparando o modelo que só leva em conta a variável chance com o modelo que considera chance + conpart

QUADRO 2.1 - Classificação dos partidos conforme seu grau de desenvolvimento organizacional 53

QUADRO 3.1 - Classificação de sistemas partidários. 69

QUADRO 3.2 - Influência dos sistemas eleitoral e partidário no número de partidos 73

QUADRO 3.3 - Número de candidatos lançados pelos grandes partidos e razão sf nas disputas pela Presidência da República entre 1994 e 2006 91

FIGURA 2.1 - Processo de formação dos órgãos de deliberação e direção dos partidos brasileiros 46 FIGURA 4.1 - Posições assumidas pelos candidatos no Modelo de Palfrey (1984)... 100

FIGURA 4.2 - Valores preditos, valores esperados, primeiras diferenças e razão de risco da probabilidade de se lançar candidatos a prefeito quando não se tem chance e se passa de comissão provisória (x) para diretório (x1), dentro de um intervalo de $95 \%$. 123 


\section{CAPÍTULO 1 - INTRODUÇÃo}

Em 15 de janeiro de 1985, foram realizadas as últimas eleições indiretas no Brasil desde a implantação do regime militar em 1964. Desde então, durante 24 anos, a democracia brasileira se mantém estável, passando incólume por testes duros como a incerteza sobre quem, diante do repentino falecimento do presidente eleito Tancredo Neves, deveria tomar posse em 1985; o impeachment do presidente Collor; a eleição de um operário para a Presidência da República e grandes escândalos de corrupção.

A estabilidade da democracia brasileira, positiva do ponto de vista normativo, apresentou um grande desafio para a ciência política. A maior parte dos trabalhos desenvolvidos durante a década de 1980 e começos da de 90 , fazia prognósticos sombrios sobre as chances de sobrevivência do novo regime.

Esses prognósticos eram oriundos tanto de uma orientação sociológica, que via o sistema político como incapaz de canalizar as demandas sociais advindas da modernização da economia, quanto de um determinado neo-institucionalismo, que pregava a instabilidade congênita do sistema político brasileiro. Uma síntese deste último ponto de vista aparece em um artigo de Scott Mainwaring, de 1993, com um título esclarecedor: "Presidencialism, Multipartism and Democracy, The Difficult Combination”.

Reproduzimos abaixo o resumo do artigo, que explicita os mecanismos institucionais que levariam à instabilidade do sistema: 
Starting from recent analyses that have argued that presidentialism is less favorable for building stable democracy than parliamentary systems, this article argues that the combinations of a multiparty system and presidentialism is especially inimical to stable democracy. None of the world's 31 stable (defined as those that have existed for at least 25 consecutive years) democracies has this institutional configuration, and only one historical example - Chile from 1933 to 1973 - did so. There are three reasons why this institutional combination is problematic. First, multiparty presidentialism is especially likely to produce immobilizing executive/legislative deadlock, and such deadlock can destabilize democracy. Second, multipartism is more likely than bipartism to produce ideological polarization, thereby complicating problems often associated with presidentialism. Finally, the combination of presidentialism and multipartism is complicated by the difficulties of interparty coalition building in presidential democracies, with deleterious consequences for democratic stability. (MAINWARING, 1993:198)

As variáveis que explicariam o fracasso inevitável de nossa democracia estariam na combinação do presidencialismo com o multipartidarismo. $\mathrm{O}$ fato de que a democracia brasileira está às vésperas de comemorar seu $25^{\circ}$ aniversário e assim se tornar uma democracia estável pelo critério de Mainwaring, mostra que as variáveis sistema de governo e sistema partidário não eram suficientes para explicar a estabilidade ou instabilidade de regimes democráticos. 
Uma crítica ao trabalho de autores da linha de Mainwaring aparece nos escritos de Argelina Figueiredo e Fernando Limongi (Figueiredo e Limongi, 1995, 1999, 2000). Os principais pontos desta crítica são sintetizados em um artigo de Limongi, publicado em 2003.

\section{Conforme Limongi:}

Olhando atentamente os argumentos, veremos que, no mais das vezes, as diferenças que se atribui à forma de governo são derivadas, na realidade, da variação das suposições comportamentais. Os críticos do presidencialismo raciocinam com modelos em que, nessa forma de governo, os políticos são "míopes" (só pensam nos resultados eleitorais imediatos) e/ou office seeking (tudo que querem é o cargo de presidente), enquanto, sob parlamentarismo, eles agem com base em ganhos de longo prazo e têm preferências por políticas.

\section{(...)}

...a variação é menos institucional e mais comportamental. As premissas relativas ao comportamento dos atores variam com as instituições. Por que eleitores, sob presidencialismo, seriam menos capazes de incorporar as consequiências de seus atos em seus cálculos? Da mesma forma, por que os objetivos dos políticos seriam diversos em uma e outra forma de governo? Notadas essas inconsistências, fica claro que o poder explicativo dos argumentos levantados se vê prejudicado. É impossível distinguir o que cabe às instituições e o que cabe à variação na racionalidade do eleitor.

(LIMONGI, 2003) 
Essa crítica aponta para o equívoco de se associar incentivos a resultados sem levar em consideração o processo pelo qual as decisões são tomadas, e para os perigos de se atribuir a diferentes resultados diferenças comportamentais mais assumidas do que comprovadas.

No caso da relação entre Executivo e Legislativo, como vimos na passagem acima, atribuise aos políticos em sistemas presidencialistas um comportamento a priori diferente daquele dos políticos em sistemas parlamentaristas. Enquanto políticos parlamentaristas pensam estrategicamente no longo prazo, os políticos presidencialistas seriam "míopes", agindo sempre em curto prazo. No presidencialismo, os políticos, para garantir a sua reeleição, agiriam de maneira individualista, buscando satisfazer sua clientela e garantindo os seus votos. O principal problema desta teoria reside no fato de que, quando se examina como funciona o congresso, vê-se que os políticos dependem das lideranças partidárias para obter recursos. O processo de tomada de decisão no interior do congresso cria incentivos ao comportamento partidário.

O mesmo se dá com relação à arena eleitoral. A legislação eleitoral e as normas organizacionais gerariam incentivos para um comportamento individualista por parte dos políticos e os partidos não controlariam os recursos necessários para disciplinar este comportamento. Esse comportamento dos políticos se deveria ao fato das lideranças partidárias não terem controle sobre a lista de candidatos. No Brasil, os partidos seriam fracos.

Como se vê, o foco dessa literatura são as eleições para o Legislativo, que se dão sob o sistema de representação proporcional de lista aberta. Embora as eleições para o Legislativo sejam importantes elas não são, como nos regimes parlamentaristas, as eleições mais 
importantes. No Brasil, os cargos majoritários detêm o controle da formulação de políticas e da distribuição da maior parte dos recursos ambicionados pelos políticos. O foco da análise deve, portanto, deslocar-se do controle sobre a lista de candidatos na eleição proporcional para o controle sobre a indicação de candidatos a cargo majoritário e, antes disso, ao controle sobre a decisão de se lançar ou não um candidato.

Dessa forma, ao se mudar o foco da análise para as eleições majoritárias, deve-se analisar o processo de tomada de decisão no interior dos partidos, buscando os mecanismos pelos quais os dirigentes controlam a organização e as estratégias eleitorais partidárias.

O presente trabalho tem como um de seus intuitos preencher duas lacunas: a falta de estudos sobre os processo decisórios no interior dos partidos e a falta de estudos sobre os efeitos do sistema majoritário sobre as estratégias eleitorais. Iremos analisar como funcionam os partidos e mostraremos que há vida partidária e que ela é rica e complexa em termos de mecanismos institucionais que, na maior parte dos casos, dão grande poder às lideranças frente aos membros da organização.

Iremos analisar também como se dá a coordenação eleitoral e seu efeito no número de partidos. Não obstante a importância dada aos efeitos deletérios atribuídos ao multipartidarismo, não há estudos brasileiros que testem os efeitos da única proposição que recebeu o status de lei na Ciência Política, a chamada Lei de Duverger. Isto é, não há estudos que buscam entender, à luz desta Lei e de forma aprofundada, porque temos a quantidade de partido que temos.

Como veremos adiante, a Lei de Duverger associa o número de partidos ao sistema eleitoral adotado. Sistemas como o que o Brasil adota nas eleições para Prefeito, Governador e 
Presidente imporiam uma barreira ao número de candidatos em disputa. Essa barreira se deve ao voto estratégico por parte do eleitor ou à coordenação pré-eleitoral por parte das lideranças políticas. Portanto, verificar os efeitos da Lei de Duverger significa examinar como se dá a coordenação eleitoral - ou a falha de coordenação eleitoral - o que tem conseqüências importantes tanto do ponto de vista positivo, quanto normativo.

É surpreendente que, diante do grande número de eleições majoritárias, diante da única proposição que conquistou o status de Lei na Ciência Política e diante da quantidade e qualidade dos estudos sobre o assunto fora do país, tão pouco esforço tenha sido feito por parte de pesquisadores brasileiros para verificá-la.

O teste da Lei de Duverger mostrará que o efeito redutor dos sistemas majoritários se aplica ao caso brasileiro. Veremos que no Brasil prevalece a coordenação entre lideranças partidárias por meio de coligações eleitorais e, quando esta coordenação falha, os eleitores exercem o chamado "voto estratégico".

Nossa análise sobre a organização partidária e sobre a coordenação eleitoral levará à hipótese de que o tipo de organização partidária tem impacto na decisão de um partido em lançar ou não um candidato. Vários autores, fora do Brasil, se dedicaram a construir modelos que explicam as condições sob as quais é racional se lançar em uma disputa. Iremos nos basear nestes estudos e nestes modelos para testar nossa hipótese. Veremos que uma variável importante para explicar a decisão de um partido de lançar um candidato é o grau de controle que as lideranças exercem sobre a organização partidária. Quanto menos concentrado é o controle sobre as decisões partidárias, maior a dificuldade para o partido coordenar com outros partidos antes da abertura do processo eleitoral, isto é, maior a 
probabilidade de falha na coordenação pré-eleitoral. As "bases partidárias" se mostram mais reticentes do que as lideranças em se aliar com outras forças políticas.

Veremos que a falha de coordenação eleitoral está ligada, em sistemas majoritários, a uma menor representatividade. Nos sistemas majoritários de um só turno - que é o caso das eleições brasileiras para Prefeito em municípios com menos de 200 mil habitantes - um partido que não representa a maioria pode sair vencedor, pois outros partidos, mais próximos à vontade da maioria, podem acabar dividindo os votos. No caso das eleições de dois turnos - o caso das eleições em municípios com mais de 200 mil habitantes, governos de estado e Presidência da República - isso também pode ocorrer quando vários partidos dividem o voto e deixam passar para o segundo turno opções que seriam derrotadas caso houvesse coordenação ${ }^{1}$.

Ao rever conceitos e trazer à luz dados pouco explorados, o presente trabalho procura propiciar uma melhor compreensão da arena eleitoral brasileira. Ressaltamos: os partidos têm vida e esta vida tem impacto nas configurações que as disputas eleitorais assumem, aumentando ou diminuindo a probabilidade de coordenação eleitoral e, assim, aumentando ou diminuindo a representatividade do sistema.

Além desta introdução e da conclusão, o texto se divide da seguinte forma: no próximo capítulo, dedicar-nos-emos à organização partidária e mostraremos como os partidos funcionam no Brasil, chamando a atenção para o controle que as lideranças exercem sobre

\footnotetext{
${ }^{1}$ Um exemplo foi a eleição para Presidente de 1989. Nesta eleição, passaram para o segundo turno Fernando Collor e Luis Inácio Lula da Silva, respectivamente o candidato mais à direita e mais à esquerda. Uma combinação de centro-esquerda (PMDB, PSDB e PDT) teria $32 \%$ dos votos e garantiria sua presença no segundo turno, o mesmo ocorrendo com uma combinação de centro-direita (PMDB, PSDB, PL, PFL), que teria $22 \%$.
} 
as decisões estratégicas de maior interesse para a organização. Iremos analisar o processo de tomada de decisão no interior dos partidos, identificando os mecanismos institucionais fundamentais para que as lideranças tenham controle sobre suas organizações. Nossos principais resultados são, por um lado, a identificação do uso estratégico das comissões provisórias, que conferem um grande poder a algumas lideranças e, por outro, a diferenciação dos partidos quanto ao maior ou menor controle sobre este instrumento e, portanto, sobre o processo interno de tomada de decisão. O Capítulo 3 será dedicado à Lei de Duverger, testando seus efeitos nas eleições para Prefeito, Governador e Presidente. Veremos que a coordenação pré-eleitoral ocorre em quase todas as disputas e, quando ela não ocorre, os eleitores acabam por fixar seus votos nos candidatos mais viáveis. $\mathrm{O}$ Capítulo 4 tratará dos chamados "modelos de entrada" e fará a ligação entre os dois capítulos anteriores, propondo que a organização partidária tem impacto na decisão de um partido em lançar ou não um candidato. Mostraremos que quanto mais descentralizado um partido, maior a possibilidade de ele lançar um candidato, mesmo que ele não tenha chances de vitória. No quinto capítulo, daremos mais concretude à análise, mostrando como a relação entre organização e estratégia eleitoral se dá em alguns partidos brasileiros. 


\section{CAPÍTULO 2 - VIDA PARTIDÁRIA}

\subsection{Introdução}

Ao se aproximarem as eleições para prefeito de 2008, os jornais de maior circulação do país deram destaque às disputas para indicação de candidatos nas cidades de Belo Horizonte e São Paulo. Esse destaque não se deve apenas ao fato de se tratar de duas das maiores metrópoles brasileiras; o que chamou a atenção da imprensa foi o fato de que nestas duas capitais houve disputa no interior dos principais partidos quanto à estratégia de coligação e quanto à indicação do candidato.

Em Belo Horizonte, apesar de serem adversários ferrenhos no nível federal, o PSDB, que ocupava o Governo do Estado, e o PT, que detinha a Prefeitura Municipal, entraram em acordo para lançar um candidato de um terceiro partido, o PSB. Essa candidatura, com o apoio de partidos tão fortes localmente seria imbatível, na opinião de seus artífices. Apesar de este arranjo ser considerado a melhor estratégia no nível local, a Executiva Nacional do PT não concordou e vetou a coligação com o PSDB, pois, para a Executiva, esta estratégia serviria para alavancar a candidatura de Aécio Neves (do PSDB e Governador do Estado) à Presidência da República. O PSDB se retirou formalmente da coligação, não lançou candidato próprio, mas manteve o apoio não oficial à candidatura do PSB que, no entanto, perdeu um tempo precioso de seu horário gratuito de propaganda eleitoral.

Em São Paulo, a maior cidade do país, a disputa se deu no interior do PSDB. O partido, que ocupava o Governo do Estado desde 1995 e que havia vencido a disputa pela Prefeitura em 
2004, viu-se dividido entre lançar um candidato próprio e apoiar o Prefeito Gilberto Kassab. Filiado ao DEM, Kassab foi eleito Vice-Prefeito na coligação com o PSDB em 2004 e assumiu a Prefeitura em 2006, quando José Serra renunciou ao cargo para concorrer ao Governo do Estado. A candidatura própria parecia a melhor estratégia para o PSDB local, já que o candidato proposto, Geraldo Alckmin, ex-Governador do Estado, aparecia entre os primeiros colocados nas pesquisas de opinião pública, enquanto o Prefeito em exercício ficava bem atrás. No entanto, a aliança com o DEM era vista como estratégica pelo Governador José Serra, em função de sua pretensão de se candidatar à Presidência da República. Nas últimas horas que antecederam a convenção, houve a retirada da chapa que propunha a aliança com o DEM e vingou a candidatura Alckmin.

Outros partidos aparentemente não enfrentaram as mesmas disputas. O DEM em São Paulo e em Belo Horizonte, assim como em outras capitais, lançou candidatos e optou por alianças sem maiores problemas; o mesmo se deu com o PTB e com o PDT. Mas se olharmos mais de perto o que se passou no interior destes partidos, veremos que não se tratou de ausência de conflito, mas sim de uma total assimetria de poder entre a direção nacional e o nível local. O DEM, ao mudar o nome da legenda e o estatuto do partido em 2007, dissolve todos os órgãos partidários, colocando em seu lugar comissões provisórias nomeadas pela comissão executiva, o que permitiu a neutralização de possíveis dissensos. No PTB, a pretexto da fusão com o PAN, os órgãos partidários também são dissolvidos em 2007. No PDT, o controle da Executiva do partido, comandada por Leonel Brizola, desde a origem do partido em 1980 até sua morte em 2004, era total e determinava a obrigatoriedade de candidatura própria em todas as eleições. 
Esses episódios mostram que há muito mais vida partidária do que considera a literatura da Ciência Política. Eles evidenciam a existência de disputas internas e mostram que essas disputas envolvem a utilização de mecanismos pouco conhecidos e estudados pelos cientistas políticos.

O presente capítulo pretende analisar o processo de tomada de decisão no interior dos partidos, identificando os mecanismos institucionais fundamentais para que as lideranças tenham controle sobre suas organizações. Nossos principais resultados são, por um lado, a identificação do uso estratégico das comissões provisórias, que conferem um grande poder a algumas lideranças e, por outro, a diferenciação dos partidos quanto ao maior ou menor controle sobre o processo de tomada de decisão.

Ao defender a tese de que há vida partidária, a presente pesquisa vai na contramão da literatura sobre os partidos políticos brasileiros, principalmente daquela que vê na fraqueza partidária a origem das mazelas da política brasileira. Iremos mostrar que esta literatura sofre dos mesmos "preconceitos" identificados por Angelo Panebianco² e peca por se basear em poucos dados empíricos e em imprecisões teóricas.

\footnotetext{
${ }^{2}$ Panebianco identifica, entre as causas da resistência em se estudar a organização partidária, dois preconceitos: o preconceito sociológico e o preconceito teleológico. O primeiro considera a atividade dos partidos apenas como produto das demandas de grupos sociais específicos e os conflitos internos do partido como reflexo de conflitos de classe entre lideranças e base. O preconceito teleológico consiste em atribuir, a priori, alguns objetivos ao partido e suas características organizativas serão deduzidas destes objetivos (PANEBIANCO, 2005)
} 


\subsection{0 problema da "vida partidária" e a "fraqueza" dos partidos}

No Relatório Final da Comissão Temporária Interna do Senado encarregada de estudar a reforma político-partidária o relator, senador Sérgio Machado, escreve que "nos debates e depoimentos realizados, a Comissão diagnosticou que o principal problema é a fragilidade da vida partidária brasileira. A nossa legislação tem conduzido, sempre, ao enfraquecimento dos partidos políticos e ao reforço da atuação individual".

Para os Senadores e para as diversas personalidades políticas que passaram pela comissão teríamos um problema de governabilidade e a causa deste problema seriam os partidos fracos que impediriam a "consolidação das instituições democráticas":

\footnotetext{
"Como tentativa de equacionar o problema, a Comissão tem por objetivo buscar o fortalecimento dos partidos. Acreditamos que este fortalecimento resultará na estabilidade política, consolidação das instituições democráticas, e garantia da governabilidade, na medida em que permite o estabelecimento de canais de manifestação da vontade popular facilmente identificáveis" (SENADO, 1998).
}

Para o senador, o executivo não conseguiria identificar no legislativo uma maioria clara e, por isso, teria que partir para negociações individuais dificultando a implantação de suas políticas.

Esse diagnóstico não é novo. Em 1965 Afonso Arinos escrevia:

(...) a representação proporcional era destinada a enfraquecer politicamente o Presidente; a verdade, porém, é que, na prática, mais que ao Presidente ela veio enfraquecer politicamente o Congresso... A atomização das maiorias, 
principalmente na Câmara, retira a qualquer partido a possibilidade de controlar a situação, seja nas comissões, seja em plenário. Os pequenos partidos podem adquirir uma importância desmesurada, muito maior que seu peso numérico, sempre que o resultado das votações for apertado. Maiorias flutuantes e precárias, integradas por grupos que se aproximam sem se juntar, impõem uma constante necessidade de transações, às vezes no pior sentido, isto é, no sentido de barganha, de troca de vantagens, até de chantagens e de corrupções (citado em Souza, 1976, pg. 119).

Nesta passagem o problema está bem definido: a representação proporcional, mais especificamente a representação proporcional com lista aberta. Esse sistema tem como efeito um aumento no número de partidos e, muitas vezes, para se formar maiorias é necessário contar com pequenos partidos que teriam assim um poder bem maior que sua representatividade.

Conforme o relatório da comissão do Senado "isso [a fraqueza dos partidos] pode ser verificado a partir do nosso sistema eleitoral, proporcional com listas abertas, que, conforme asseverou o Ministro Jobim, além do Brasil, só é praticado na Finlândia ${ }^{3}$. Tal sistema incentiva a disputa no seio dos partidos, dificultando, sobremaneira, a coesão partidária". Como remédio a esse mal o relatório trazia propostas pra fortalecer os partidos principalmente o fim do sistema proporcional de lista aberta, a fidelidade partidária e a cláusula de barreira.

\footnotetext{
${ }^{3}$ Na verdade além do Brasil e Finlândia outros países também adotam a lista aberta como é o caso da Polônia, do Peru e do Chile. Este último caso é especialmente interessante pois o Chile é tido como exemplo de país latino-americano com partidos fortes.
} 
Maria do Carmo Campello de Souza em seu estudo sobre o Estado e os partidos no Brasil entre 1930 e 1964 (Souza, 1976) identifica uma "doutrina antipartido" hegemônica na década de trinta e que irá continuar a produzir efeitos "fornecendo o quadro de referência dentro do qual intelectuais, jornalistas e mesmo políticos avaliavam o fenômeno partidário" (Souza 1976, pg. 83).

Esse "quadro de referência" aparece de forma diferente em várias épocas e em vários autores. No começo da década de 1980, em pleno processo de abertura, uma das principais questões sobre a qual os cientistas políticos brasileiros se debruçaram se relacionava às chances de sucesso do processo de democratização. A resposta para isso, seguindo os ensinamentos de Samuel Huntington, deveria ser buscada na análise do grau de institucionalização política. As conclusões eram desanimadoras, nossas instituições eram frágeis e a raiz do problema estava nos partidos.

Na década de 90 a influência teórica é outra. Seguindo a escola da escolha racional alguns autores irão procurar entender o comportamento político por meio das regras eleitorais e partidárias. Existiria uma relação entre sistema eleitoral e o grau de cooperação entre os políticos.

Um dos modelos sugeridos para explicar essa relação foi elaborado por Carey e Shugart (1995). Para estes autores variáveis como o controle que as lideranças têm sobre o acesso à legenda e à posição na lista, o grau em que os votos são agrupados ou contados individualmente, o número e o tipo de voto dado (múltiplo, único, transferível ou não transferível) e a magnitude do distrito gerariam incentivos a um comportamento mais ou menos individualista. 
Com base nestas variáveis esses autores constroem uma escala que vai de 1 a 13 , desde os sistemas que mais criam incentivos para o comportamento cooperativo até aqueles que mais criam incentivos para um comportamento individualista. O Brasil é classificado no nível nove. No Brasil, a representação proporcional de lista aberta e a candidatura nata, em vigor na época, gerariam incentivos para o comportamento individualista ${ }^{4}$.

Assim, por meio de dois paradigmas diferentes ,chega-se à mesma conclusão: os partidos seriam fracos ora por não canalizar as demandas sociais, ora por sofrer a influência de um sistema eleitoral que não gera incentivos para um comportamento cooperativo por parte de seus membros. De um lado temos um divórcio entre os representantes partidários e seu eleitorado, de outro temos um divórcio entre os membros do partido e suas lideranças.

Com o correr do tempo e com a democracia passando incólume por testes duros como o processo de impeachment contra um presidente e o afastamento de políticos corruptos do Congresso, começaram a surgir trabalhos que discordavam do diagnóstico de subdesenvolvimento das instituições e com o prognóstico de instabilidade e crise institucional. Um trabalho que, de maneira pioneira, jogou nova luz ao debate foi o de Argelina Figueiredo e Fernando Limongi. Estes autores não só reintroduziram o tema do Poder Legislativo, abandonado durante o período do regime militar (LIMA Jr., 1999), como demonstraram que os níveis de disciplina no Congresso não eram baixos e que os partidos desempenhavam importante função nesta arena (FIGUEIREDO e LIMONGI, 1995 e 1999).

\footnotetext{
${ }^{4}$ Deve ser notado, no entanto que que se não for considerada a candidatura nata a "nota" do Brasil se iguala a do Chile, um país com regras que incentivam o comportamento cooperativo. Como se sabe a candidatura nata não mais existe, ainda assim Brasil e Chile continuam a ser tratados como antípodas pelos analistas.
} 
Outros trabalhos vêm reforçar uma perspectiva mais positiva quanto aos partidos brasileiros. Leôncio Martins Rodrigues (2002) fez um balanço destas contribuições e sugeriu que, além de serem mais disciplinados do que se imaginava, os partidos se distinguiriam ideologicamente (RODRIGUES, 2002) e a volatilidade eleitoral deveria ser relativizada (PERES, 1999).

Esses trabalhos, portanto, desafiam a visão do divórcio entre os membros dos partidos e suas lideranças. Há algum mecanismo que assegura o controle do partido por parte das lideranças e a tarefa passa a ser identificar quais são esses mecanismos.

No entanto essa perspectiva mais positiva dos partidos também não se apóia em estudos da organização partidária e fica restrita à arena parlamentar. Nenhuma das análises olha para dentro do partido, isto é, busca entender quais fatores organizacionais impactam na maior ou menor cooperação entre seus membros. As variáveis que demonstram ora a força, ora a fraqueza dos partidos são externas a eles: votos, cadeiras no parlamento, identidade partidária, votação dos deputados, migração partidária, características do sistema eleitoral, volatilidade, representatividade, etc.

Meu intuito, neste capítulo, é tentar entender como os partidos brasileiros funcionam e quais características da organização partidária influem no maior ou menor controle sobre as decisões partidárias. Mostraremos que os partidos se diferenciam quanto à centralização do controle das suas decisões e que partidos aparentemente fracos têm na verdade muita força. Mas antes de chegar nestas conclusões precisamos definir melhor o objeto de nosso estudo, os partidos políticos. 


\subsection{0 conceito de partido político}

A pouca relevância dada à organização partidária não é privilégio da ciência política brasileira. Conforme Peter Mair (1994), apesar do estudo dos sistemas partidários e dos partidos ter se tornado um dos mais ativos temas dentro do campo da política comparada, o estudo empiricamente orientado dos partidos, enquanto organizações, ainda era uma das grandes lacunas neste campo.

Para Mair, um dos sintomas da pouca atenção à organização partidária é a persistência de termos de referência estabelecidos há mais de meio século pela obra seminal de Maurice Duverger (1971). Conforme Seiler "as contribuições dos cientistas políticos posteriores consistiram ora em melhorar o paradigma de Duverger, ora em plagiá-lo totalmente" (SEILER, 2000), tendo ocorrido poucos avanços desde os anos 60.

Exageros à parte, o fato é que o modelo de partido de massas, consolidado por Duverger, mas já vislumbrado por Max Weber, tem sido, ainda hoje, utilizado como parâmetro nas analises de diversos sistemas partidários. Como nos diz Peter Mair:

In this view, party organizations are defined primarily with reference to their relationships with civil society; party organizational strength is measured primarily with reference to the size of the membership and the capacity of the party to close off (often predefined) sectors of the electorate; and party structures are understood and assessed primarily in terms of modes of internal representation and 
accountability. It follows therefore that the attenuation of any of these elements (...) involves also the attenuation, and decline, of party per se (MAIR, 1994, p. 2).

Os partidos de massa surgem com a ampliação do sufrágio e com a incorporação de novos atores à arena política. Duverger (1971) estabelece uma distinção entre os partidos de massa emergentes e os partidos de quadros que dominavam a arena política até então. Os partidos de quadros se originaram nos parlamentos, em meio às "oligarquias censitárias", quando a participação política se restringia a essas oligarquias. Os partidos de massa têm origem externa, nascem do movimento operário, dos movimentos camponeses ou impulsionados pela igreja.

O partido de massa se tornou um "canal” de expressão política para as camadas recém incorporadas à sociedade, integrando, socializando e mobilizando essas camadas dentro do jogo democrático e, em nome dela, formulando políticas públicas e selecionando seus executores.

A base social dos partidos de massa foi vista como a fonte da legitimidade dos sistemas políticos. A democracia funcionaria porque os partidos refletiriam a vontade da sociedade e promoveriam a ligação entre os cidadãos e o Estado. Neste sentido, os partidos de massa seriam essenciais para a estabilização do sistema partidário. Por meio do "encapsulamento" de seções do eleitorado e pelo estabelecimento de identidades políticas duráveis, os partidos de massa promoveriam a estruturação do comportamento político e a consolidação do sistema partidário (MAIR, 1990).

Desta forma, estabeleceu-se uma relação direta entre estabilidade e partidos de massa e, mais ainda, surgiu a crença de que o partido de massa seria o estágio mais avançado do 
“desenvolvimento político" ou da "consolidação dos sistemas partidários" (SARTORI, 1982). Para Sartori, sistemas partidários consolidados deveriam contar com partidos de massa nacionalmente organizados. Essa consolidação seria a contraparte da atomização partidária baseada em lealdades pessoais. Sempre que prevaleçam as lealdades pessoais, as identidades políticas e a vinculação dos cidadãos com as arenas públicas de tomada de decisão se enfraquecem (KINZO, 2004). A própria legitimidade dos partidos é posta em questão e o funcionamento da democracia estaria ameaçado.

Assim os partidos de massa se tornaram a régua que mediria o desenvolvimento partidário dentro de uma perspectiva comparativa. Quando os partidos de um determinado país não apresentavam as características do partido de massas o sistema partidário deste país era considerado pouco consolidado, um sinal de que a própria democracia estaria ameaçada.

$\mathrm{N}$ os anos 70 e, com o aumento da volatilidade eleitoral na Europa abalou estas crenças. Os eleitores pareciam não ter o mesmo grau de identificação partidária que antes, e os partidos de massa começaram a perder filiados, a própria massa. Frente a isso a literatura começou a se dedicar às mudanças nos sistemas partidários. Parecia claro, para vários autores, que eles estariam vivendo um momento de profundas transformações que levaria ao surgimento de uma nova era da política onde as clivagens não seriam tão estanques, as divisões sociais não seriam mais tão relevantes para a política e os partidos estariam em decadência (MAIR, 1990).

Essas transformações foram prenunciadas ainda nos anos 60 por Otto Kirchheimer. Assim como Duverger, que apontou a superação do modelo do partido de quadros pelo modelo do partido de massa, Kirchheimer propôs a superação do partido de massa pelo que veio a 
denominar como partido "pega tudo" ("catch-all parties"). A prevalência dos partidos “catch-all” seria um indicador de que o sistema político estava se tornando vulnerável.

Os partidos “catch-all” são caracterizados por redução da ênfase na ideologia, fortalecimento das lideranças partidárias, redução do papel da militância, ausência de uma classe específica de onde sairiam seus votos e por um processo de aproximação a vários grupos de interesse.

Na visão de Kirchheimer, os partidos “catch-all” adotariam um comportamento mais independente e mais distante com relação a segmentos do eleitorado que antes se expressavam politicamente por meio dos partidos de massa. Esse distanciamento estaria expresso na prevalência das lideranças sobre as bases e a independência se traduziria na procura do apoio do eleitor em geral e não mais no "encapsulamento" de parte do eleitorado. Angelo Panebianco agrega à análise de Kirchheimer o aspecto da crescente profissionalização dos partidos, propondo o modelo do partido eleitoral-profissional.

Um denominador comum a essas análises é a visão segundo a qual a nova organização partidária que surge nos anos 70 levaria ao enfraquecimento da função integrativoexpressiva dos partidos que, por sua vez, levaria à difusão de comportamentos políticos não convencionais, facilitaria a explosão de reivindicações corporativas e desencadearia a multiplicação das estruturas de representação de interesses. Os partidos passariam a competir com outras organizações sem o elemento que pesava a seu favor no status quo 
anterior: a capacidade de organizar e representar interesses coletivos. Ou seja, a democracia na Europa estaria em crise ${ }^{5}$.

No entanto a Europa continuou democrática e os cientistas começaram a rever seus prognósticos. Para Mair o problema foi tomar o declínio do partido de massa como o declínio dos partidos em geral. Mair propõe inverter o foco da análise. No lugar das conexões entre o partido e a sociedade, ele irá focar as relações entre partido e Estado e mostrar que o enfraquecimento do elo entre o partido e a sociedade teria como contrapartida o fortalecimento do elo entre o partido e o Estado. As lideranças partidárias tirariam seu poder e sua legitimidade do Estado. Este forneceria os recursos necessários à manutenção dos partidos e das lideranças, dentre eles: o acesso aos meios de comunicação, a contratação de pessoal (alocado nos gabinetes de deputados e de membros do executivo), o financiamento público de campanha e o fundo partidário.

A conclusão de Mair é a de que os partidos não estariam declinando, mas sim mudando. Estaria havendo um predomínio do "partido no poder" 6 sobre os demais estratos, maior profissionalização da "direção partidária" e estaria se atribuindo maior relevância ao papel dos militantes pela ampliação da democracia partidária em detrimento de sua quantidade.

\footnotetext{
${ }^{5} \mathrm{O}$ sentimento de que nos anos 70 a democracia estava em crise aparece de forma clara no relatório de Crozier, Huntington e Watanuki para a Trilateral Alliance. Neste relatório os autores afirmam que "what is in doubt today are not just the economic and military policies but also the political institutions inherited from the past. Is political democracy, as it exists today, a viable form of government for the industrialized countries of Europe, North America and Asia? Can these countries continue to function during the final quarter of the twentieth century with the forms of political democracy which they evolved during the third quarter of that century?" (CROZIER, HUNTINGTON, WATANABE, 1973, pg. 2)

${ }^{6} \mathrm{Na}$ sua análise Mair divide os partidos em três elementos, o partido na base, a direção partidária e o partido no poder, seguindo a clássica divisão porposta por Victor O. Key. Sob este prisma ele constrói a hipótese de que seria apenas o partido na base que estaria em declínio, sendo que a direção partidária e o partido no poder teriam se fortalecido a partir do aumento da quantidade de recursos a seu dispor, advindos de sua relação com o Estado.
} 
Em resumo: os partidos mudaram, os partidos de massa são apenas uma das inúmeras formas de organização partidária, os partidos devem ser vistos hoje mais na sua relação com o Estado do que em sua relação com o eleitorado e, o mais importante, o sucesso da democracia não depende da existência de partidos de massa. Prova da independência entre funcionamento da democracia e tipo de partido são os Estados Unidos. Lá os partidos nunca se constituíram enquanto partido de massas no sentido Duvergeriano, no entanto é o país com a democracia e os partidos mais longevos.

Se os partidos mudaram e se hoje assumem inúmeras formas, não podemos mais nos contentar com as classificações usuais dos partidos brasileiros, pois essas classificações foram construídas segundo o paradigma dos anos 70 e 80, utilizando como modelo o tipo ideal dos partidos de massa.

$\mathrm{Na}$ visão que impera na literatura brasileira sobre partidos políticos haveria por um lado o partido de massa com vínculos fortes com a sociedade e, por outro, partidos fracos sem vínculos sociais onde predominariam as relações pessoais (KINZO, 1993). Dentro deste esquema um partido que não fosse um partido de massa não teria controle sobre seus membros e não teria importância nas arenas eleitoral e legislativa. No Brasil a ausência dos partidos de massa levaria à fragmentação e à instabilidade do sistema partidário.

Essa visão, combinada com aquela outra que, como vimos, associa o sistema eleitoral brasileiro com um comportamento individualista por parte dos políticos, levou à crença, pouco fundamentada, de que no lugar dos partidos de massa existiriam apenas agrupamentos de políticos com pouca coisa em comum a não ser os vínculos pessoais que 
mantinham com suas respectivas bases. Essa visão dominante na ciência política brasileira desestimulou o estudo da organização partidária.

Hoje, diante da falta de embasamento empírico dos estudos citados e diante do avanço teórico representado pela obra de Katz e Mair, devemos voltar nossas atenções para a organização partidária procurando identificar quais os formatos que os partidos brasileiros adotaram.

A questão que se coloca, diante da ausência de um modelo de partido para o qual todas as organizações com este nome convergiriam, é como caracterizá-los, isto é, o que define um partido?

Conforme veremos com mais detalhes mais adiante, os partidos se formam para atender as necessidades de coordenação de políticos para fazer frente a problemas de escolha social e ação coletiva nas arenas eleitoral e parlamentar (ALDRICH, 1995). Os partidos existem porque a melhor estratégia para os políticos conseguirem o que querem é atuar coletivamente.

Ao criarem os partidos os políticos procuram moldá-lo às suas necessidades, eles escolhem, com maior ou menor liberdade, as regras que os regem tendo em vista a conquista e a manutenção do poder. Dependendo das circunstâncias em que a escolha das regras é feita, cada partido passa a ter uma fisionomia própria, um tipo de organização.

Panebianco (2005) sugere uma tipologia da "ordem organizativa" dos partidos onde a principal característica definidora é o grau de centralização/descentralização do poder no 
interior da organização ${ }^{7}$. As principais variáveis utilizadas por Panebianco para descrever a ordem organizativa são o grau de coesão da coalizão dominante, isto é, a concentração/dispersão do controle sobre as "zonas de incerteza", no interior do partido; a estabilidade da coalizão dominante, ou seja, sua capacidade em articular o apoio dos grupos internos; e o mapa organizativo que é a forma que assumem as relações de dominação/subordinação entre a direção partidária, o "partido no parlamento" e as organizações locais.

A tipologia de Panebianco mostra que, quanto maior o controle que a coalizão dominante tem sobre os recursos partidários e quanto maior seu poder frente aos outros grupos, mais estável é esta coalizão. Teríamos assim, de um lado, partidos oligárquicos ou monocráticos com coalizões dominantes fortes e estáveis, e de outro partidos poliárquicos divididos e instáveis. É importante ressaltar que esta tipologia independe da ideologia partidária ou do fato do partido se organizar como um partido de massas, catch-all, ou qualquer outro tipo. O que importa para caracterizar a fisionomia de um partido é o grau de centralização/descentralização do poder da coalizão dominante.

O nosso intuito é descrever a fisionomia dos partidos brasileiros. Para isso iremos adotar a perspectiva de Panebianco e buscaremos entender o funcionamento dos partidos brasileiros mostrando como, a partir das escolhas das regras internas de funcionamento e de sua organização, esses partidos exercem controle sobre as decisões estratégicas, lidam com as disputas internas e se diferenciam.

\footnotetext{
7 Essa distinção segue a contraposição das "oligarquias" de Michels à "estratarquia" de Edersveld.

${ }^{8}$ Panebianco, seguindo Crozier e Friedberg (1977), descreve as "zonas de incerteza" de uma organização como os fatores em torno dos quais se desenvolvem as atividades vitais para a organização: a competência, a gestão das relações com o ambiente, as comunicações internas, as regras formais, o financiamento da organização e o recrutamento.
} 
Neste trabalho adotaremos a seguinte definição:

Um partido político é uma associação de pessoas que tem como fim a conquista do poder atuando na arena eleitoral - ao selecionar candidatos, apresentar propostas, mobilizar o eleitorado - e na arena decisória conquistando e mantendo maiorias.

Outra distinção que faremos é entre partidos fortes e partidos fracos:

Um partido forte é aquele em que a direção partidária controla as estratégias de participação nas arenas eleitoral e decisória.

Vale notar que a distinção fracos/fortes se atém a critério similar ao empregado pela literatura neo-institucionalista. Para esta, um partido é forte quando sua liderança controla os recursos que definem carreiras políticas, notadamente o acesso à lista partidária. A perspectiva que adoto precisa o momento em que este controle se dá, isto é, considera o controle das lideranças sobre as convenções partidárias, momento em que o partido toma decisões eleitorais cruciais: se lança candidatos ou se coliga e que candidato irá lançar.

Nas próximas seções examinaremos as regras e a organização dos partidos em busca dos mecanismos de controle partidário. Na seção seguinte, veremos a utilização destes mecanismos e o impacto deles sobre a coesão e a força partidária. 


\section{4 - Como funcionam os partidos brasileiros}

Para entender como funcionam os partidos brasileiros devemos, antes de tudo, entender para que servem os partidos, o porquê dos partidos. Citando Schatschneider "a political party is an organized attempt to get control of the government" (SCHATSCHNEIDER, 1942, pg. vii), do que segue a definição que estarei utilizando neste trabalho:

Partido político é uma associação de pessoas que tem como fim a conquista do poder atuando na arena eleitoral - ao selecionar candidatos, apresentar propostas, mobilizar o eleitorado - e na arena decisória, conquistando e mantendo maiorias.

Conforme Aldrich (1995) os partidos se formam para que os políticos ganhem mais, mais freqüentemente e durante o maior tempo possível. Os políticos se juntam em partidos para resolver problemas de ação coletiva e problemas de escolha social tanto na arena eleitoral quanto na arena decisória.

$\mathrm{Na}$ arena eleitoral o problema do político é a mobilização dos eleitores. Em eleições majoritárias, e mesmo nas proporcionais, o custo de mobilização do eleitor é muito alto. Um político sozinho não teria os recursos suficientes para se fazer conhecido e para angariar os votos necessários para sua eleição, já um partido pode dispor de recursos muito mais volumosos além de obter ganhos de escala.

$\mathrm{O}$ argumento de que os partidos no Brasil são fracos se baseia na suposta falta de controle da direção partidária sobre os recursos que os políticos necessitam para se eleger e para se 
manter na carreira política (SAMUELS, 1997). Conforme este argumento os políticos assumem um comportamento individualista e só se agregam em partidos por que estes têm o monopólio da oferta de candidatos a cargos eletivos. No entanto, como veremos a seguir, os partidos brasileiros de fato controlam recursos essenciais para os políticos, justamente porque tiram proveito do monopólio que detêm.

No Brasil os partidos dispõem de três grandes fontes de recursos, o Horário Gratuito de Propaganda Eleitoral, o Fundo Partidário e os cargos em comissão no setor público. Esses recursos são importantes tanto para os políticos que disputam cadeiras no legislativo, quanto para os que disputam eleições majoritárias. Se no primeiro caso os recursos necessários para se eleger são menores, no segundo os recursos do partido são essenciais, e são as disputas para cargos majoritários as mais importantes, pois, em um país como o Brasil o executivo além de controlar a elaboração de políticas públicas também controla recursos ambicionados por políticos como cargos públicos, obras, programas sociais, etc.

Para Schmitt, Carneiro e Kuschnir (1999), as lideranças controlam o acesso ao Horário Gratuito de Propaganda Eleitoral (HGPE) e esse controle funciona como uma espécie de ordenamento informal das listas partidárias. Além do acesso aos meios de comunicação, as lideranças também controlam os recursos do fundo partidário. $\mathrm{O}$ fundo partidário, instituído pela Lei dos Partidos de 1995, vem crescendo em importância no financiamento de campanhas. A tabela abaixo mostra a evolução do valor desse fundo nas eleições de 1994, 1998, 2002 e em 2003. 
TABELA 2.1 - EVOLUÇÃO DO FUNDO PARTIDÁRIO - 1994 A 2003

\begin{tabular}{lllll}
\hline & 1994 & 1998 & 2002 & 2003 \\
\hline PT & $51.210,13$ & $6.009 .277,18$ & $12.411 .907,58$ & $22.949 .148,72$ \\
PSDB & $66.954,12$ & $6.790 .011,55$ & $16.597 .499,27$ & $18.661 .290,26$ \\
PFL & $120.629,38$ & $7.040 .935,01$ & $16.375 .207,58$ & $17.529 .369,79$ \\
PMDB & $129.073,93$ & $10.278 .754,81$ & $14.361 .448,64$ & $17.281 .802,47$ \\
PPB & $91.165,88$ & $8.295 .127,30$ & $10.740 .079,30$ & $10.389 .992,20$ \\
PTB & $42.054,94$ & $2.739 .015,52$ & $5.370 .615,86$ & $6.663 .893,18$ \\
PDT & $49.840,03$ & $3.530 .986,07$ & $5.379 .574,48$ & $6.632 .641,91$ \\
Total & $552.922,41$ & $44.686 .105,44$ & $81.238 .334,71$ & $100.110 .141,53$ \\
\hline Fonte: TSE & & & & \\
\hline
\end{tabular}

Além da arena eleitoral, os partidos controlam outro recurso, talvez o mais valioso para os políticos, que são os cargos governamentais. Os cargos de confiança, aqueles que podem ser nomeados sem a necessidade de concurso público, permitem aos políticos controlar áreas de seu interesse, beneficiar apoiadores e cabos eleitorais, e, em alguns casos, obter recursos escusos para campanha.

Só o governo federal dispunha, em maio de 2008, de 20.420 cargos de Direção de Assessoramento Superior, os DAS, com uma remuneração média de R \$ 5.223,74 e um valor total cerca de R\$1,4 bilhões por ano9 . O Governo do Estado de São Paulo possuía, em julho, 12.802 titulares de cargos de comissão na ativa com um gasto total de cerca de

${ }^{9}$ Cf. Boletim Estatístico do Pessoal. Ministério do Planejamento, Orçamento e Gestão. Brasília, maio de 2008. 
$\mathrm{R} \$ 366$ milhões anuais ${ }^{10}$. Se somarmos a esses os números dos demais governos de estado e municípios teremos uma quantia gigantesca de recursos à disposição dos políticos.

Além do controle destas fontes de recursos, os partidos também controlam o processo de seleção de candidatos como mostramos em outro trabalho (GUARNIERI, 2004). Nesse trabalho, seguindo um modelo proposto por Rahat e Hazan (2001), analisamos quatro dimensões do processo de seleção: a dimensão dos candidatos, dos selecionadores, do grau de centralização e do método de escolha. Vimos que os partidos analisados têm instrumentos para restringir a entrada de postulantes a cargos eletivos, para definir quem escolhe os candidatos e para restringir a quantidade de candidatos que serão lançados. Constatamos assim que o processo é centralizado e que, na prática, as lideranças partidárias têm controle do processo. São elas que definem quem pode participar e como ${ }^{11}$.

Portanto ao contrário do que afirma a literatura os partidos controlam recursos valiosos ${ }^{12}$ para "políticos ambiciosos". O que precisamos explicar é o modo como as lideranças ganham controle sobre estes recursos. Para controlar as decisões sobre a estratégia eleitoral, que inclui a distribuição do tempo no HGPE, o uso do fundo partidário, e sobre quais serão os candidatos aos cargos proporcionais e majoritários, os políticos precisam controlar a

\footnotetext{
${ }^{10}$ Cf. Boletim Estatístico do Pessoal. Secretaria de Gestão Pública, Unidade Central de Recursos Humanos, PRODESP. São Paulo, julho de 2008.

${ }^{11} \mathrm{O}$ fato da legislação tratar o processo de escolha de candidatos como questão interna corporis faz com que o arcabouço institucional seja frágil podendo favorecer as lideranças ao remeter os casos não contemplados nas regras estatutárias à decisões ad hoc. As lideranças comandam por meio de resoluções e por meio do poder de julgar os "casos não previstos nos regulamentos". A baixa institucionalização, neste caso, seria fonte, não de fraqueza, mas sim de força partidária.

${ }^{12}$ Os recursos, HGPE, Fundo Partidário e cargos no governo são obtidos junto ao Estado. Isso indica que, assim como ocorreu na Europa nos anos 80 e 90, a relação dos partidos brasileiros com o Estado tem se tornado cada vez mais importante para a obtenção de recursos. (MAIR, 1994).
} 
organização partidária e, para entender como esse controle se dá, precisamos entender como os partidos se organizam.

\section{Como os partidos se organizam}

Sendo o objetivo maior do partido a conquista e a manutenção do poder iremos descrever seu funcionamento buscando os mecanismos que garantem às lideranças partidárias o controle sobre as decisões de participação nas arenas eleitoral e decisória. Para isso vamos, em um primeiro momento, analisar as regras constantes dos estatutos dos principais partidos brasileiros atuais ${ }^{13} \mathrm{e}$, em seguida, iremos mostrar como as lideranças partidárias utilizam de maneira estratégica estas regras para centralizar o controle sobre as decisões.

Veremos que, formalmente, as decisões partidárias são tomadas da base para o topo. No entanto veremos que as lideranças no topo do partido possuem mecanismos que lhes permitem controlar todo o processo definindo as regras segundo as quais as decisões serão tomadas e ao definir quem irá participar do processo.

Os partidos brasileiros podem lançar candidatos aos três níveis de governo: municipal, estadual e nacional e seus corpos legislativos correspondentes. A estrutura partidária corresponde a essa divisão e se organiza em diretórios municipal, estadual e nacional. Cada uma destas divisões partidárias detém certa autonomia, mas, em todos os partidos pesquisados, a instância máxima é a "convenção nacional".

\footnotetext{
${ }^{13}$ Consideramos como os "principais partidos brasileiros atuais" os partidos com 1 milhão ou mais de filiados em 2007: PP/PDS, PMDB, PTB, PDT, PT, PSDB e DEM/PFL.
} 
Os partidos pesquisados ${ }^{14}$ possuem seis tipos de órgãos partidários:

I - órgãos de deliberação: convenções nacional, estadual, municipal e zonal. É a instância responsável por escolher os candidatos, definir as alianças eleitorais, decidir sobre o programa e estatuto do partido, decidir sobre a dissolução do diretório nacional, entre outras;

II - órgãos de direção e de ação partidária: diretórios; comissões executivas nacional, estadual e municipal e comissões provisórias. Instância responsável pelos processos internos do partido como baixar normas que regulamentem o estatuto, convocar e definir as regras de funcionamento das convenções, definir intervenções, aplicar penalidades, julgar recursos, entre outras. Os diretórios escolhem as comissões executivas que exercem de fato as responsabilidades elencadas acima;

III - órgãos de ação parlamentar: bancadas parlamentares no Senado, na Câmara dos Deputados, nas Assembléias Legislativas e nas Câmaras Municipais. Cabe às bancadas orientar o voto dos parlamentares e, em alguns casos, decidir sobre a participação no governo;

IV - órgãos auxiliares: conselhos de ética e fiscal. Responsáveis pela fiscalização das finanças e dos deveres dos filiados;

V - órgão de pesquisa, doutrinação e educação política: fundações ou institutos;

\footnotetext{
${ }^{14}$ Outros partidos seguem a mesma estruturação com exceção do PCdoB que trabalha com comitês no lugar dos diretórios.
} 
VI - órgãos de cooperação: núcleos e secretariados representando segmentos sociais como jovens, mulheres, sindicatos, negros, etc..

Os órgãos mais relevantes com relação à formulação de estratégias na arena eleitoral são os de deliberação e direção partidária. Pode-se dizer que a vida partidária se resume à disputa pelo controle destas instâncias, as demais são de menor importância.

O órgão máximo de decisão partidária é a Convenção Nacional, pois é ela que decide as estratégias políticas do partido como, entre outras, as políticas de alianças eleitorais. Cabe a ela escolher os candidatos à Presidência da República. Assim, obter o controle da convenção garante o controle sobre a escolha dos candidatos a cargos majoritários e, conseqüentemente, a definição da estratégia eleitoral a ser perseguida. Logo o controle sobre a convenção garante a direção do partido. Para se entender como se dá o controle sobre a Convenção Nacional é necessário analisar o processo de formação dos órgãos partidários.

Idealmente convenções são formadas da base para o topo, do nível municipal para o nível

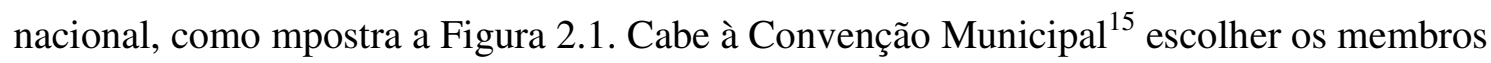
do Diretório Municipal que, por sua vez escolhem os membros da Comissão Executiva Municipal. A Convenção Municipal também escolhe os delegados à Convenção Regional ${ }^{16}$. A Convenção Regional escolhe os membros do Diretório Regional que por sua vez escolhem os membros da Comissão Executiva Regional. A Convenção Regional também

\footnotetext{
${ }^{15}$ No caso de cidades grandes, geralmente aquelas com mais de um milhão de habitantes, Convenções Zonais antecedem as Convenções Municipais.

${ }^{16}$ O caso do PT é peculiar. Este partido adotou, a partir de 2001, o Processo de Eleições Diretas (PED), pelo qual os dirigentes são escolhidos por voto direto dos filiados. Esse processo será descrito com mais detalhes no Capítulo 5.
} 
escolhe os delegados à Convenção Nacional que por sua vez escolhe os membros do Diretório Nacional que irão forma a Comissão Executiva Nacional (CEN).

FIGURA 2.1 - PROCESSO DE FORMAÇÃO DOS ÓRGÃOS DE DELIBERAÇÃO E DIREÇÃO DOS PARTIDOS BRASILEIROS

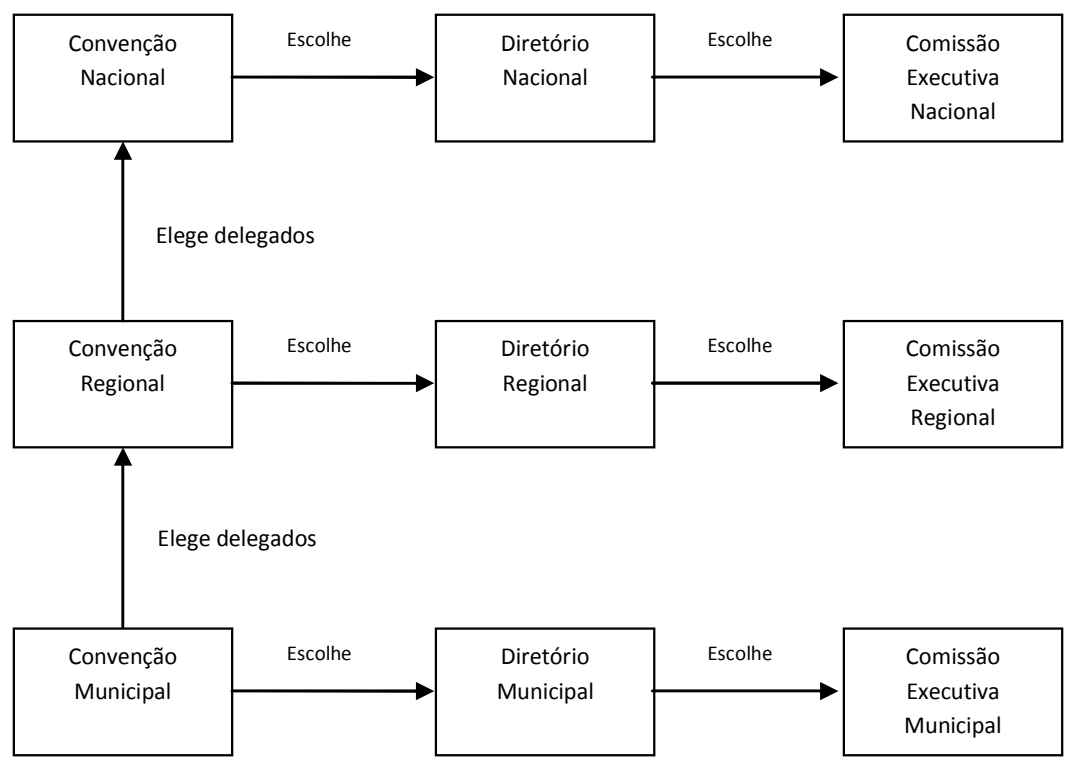

\section{Como são escolhidos os dirigentes}

Para um político se tornar parte da direção partidária é necessário ser eleito membro da Comissão Executiva e, para isso, é preciso controlar a Convenção. Para controlar a Convenção é necessário que uma chapa tenha a maioria dos votos. Para isso é necessário contar com apoio do maior número de Diretórios.

Com exceção do PT, que adotou o Processo de Eleições Diretas (PED), todos os partidos pesquisados adotam formalmente o sistema de listas fechadas. O primeiro órgão a ser escolhido é o diretório municipal. Os postulantes a uma posição neste diretório se juntam em uma ou mais chapas que são apresentadas aos filiados. Se houver apenas uma chapa 
esta é eleita se obtiver $20 \%$ dos votos, se houver mais de uma chapa vence aquela que obtiver mais de $80 \%$ dos votos ou, então, os cargos do Diretório são distribuídos proporcionalmente à votação de cada chapa ${ }^{17}$. Nas chapas também constam os delegados à convenção regional. O mesmo sistema de chapas é utilizado nas convenções regional e nacional.

Uma vez eleito o Diretório este escolhe, geralmente por maioria absoluta, os componentes da Comissão Executiva, entre eles, o Presidente e o Secretário Geral do partido. Como, formalmente, a escolha de dirigentes começa no nível local poderíamos esperar que divisões regionais no interior do partido se refletissem em divisões na coalizão dominante. Os partidos brasileiros seriam, desta forma, caracterizados como poliárquicos, seguindo a tipologia de Panebianco, com pouco controle sobre a organização e a decisão partidária. A pequena literatura que pesquisou o processo de escolha de dirigentes se baseou apenas no aspecto formal deste processo deixando de ver como ele se dá de fato ${ }^{18}$.

Embora a Convenção Nacional seja o órgão máximo do partido a agenda, isto é, as questões sobre as quais decide, a forma como serão tomadas as decisões e quem participará do processo, são definidas pela Comissão Executiva Nacional (CEN). Isto acontece porque,

\footnotetext{
${ }^{17}$ Os estatutos não são claros sobre o que ocorre quando só há uma chapa e esta recebe menos de $20 \%$ dos votos. Eles dizem apenas que a "deliberação não terá validade" ou que "não se constituirá diretório". Subentende-se que neste caso é a executiva do órgão imediatamente superior quem irá deliberar sobre a composição do diretório já que a estes órgãos cabe a deliberação quando o nível inferior não for capaz de cumprir com suas atribuições ou caso se constitua como comissão provisória.

${ }^{18}$ Mainwaring (1999) defende a idéia de que a descentralização do processo de escolha de dirigentes faz com que, em partidos catch-all, políticos utilizem suas bases locais para controlar as convenções e por isso conseguem manter um comportamento individualista. No entanto em outra ocasião (MAINWARING, 1991) o mesmo autor dizia que o PT conseguia controlar seus políticos justamente porque neste partido as decisões eram descentralizados. A diferença era que no PT, por se tratar, na concepção do autor, de um partido de massa, as bases eram formadas por militantes que se importavam mais com a ideologia partidária, enquanto que nos outros as bases se moviam por benefícios pessoais e serviam como mera massa de manobra. No entanto esses comportamentos são mais assumidos do que comprovados, Mainwaring não explicita qual o fundamento desta diferença de comportamento.
} 
além de ter o poder de convocar as convenções estipulando prazos, forma de votação e definindo quem poderá participar delas, a CEN tem, acima de tudo, o poder de dissolver diretórios e constituir comissões provisórias o que, como veremos logo abaixo, garante controle direto das convenções partidárias.

\section{Comissões Provisórias}

Apesar da adoção formal do sistema de listas fechadas para a escolha de dirigentes, que daria um caráter poliárquico aos partidos brasileiros com o poder dividido entre os diferentes níveis organizacionais, na prática, as lideranças têm um recurso normativo que permite o mais absoluto controle sobre a formação das listas. Trata-se do instituto das Comissões Provisórias.

Quando um partido surge, conforme a legislação, ele tem um ano para realizar suas convenções e constituir diretórios em pelo menos nove estados. Durante este período todo partido se constitui com comissões executivas provisórias em todos os níveis em que se faz presente $^{19}$. O nível mais alto nomeia as comissões provisórias dos níveis inferiores. Cabe a essas convocar as primeiras convenções que irão formar o partido. Essas convenções irão formar os diretórios de caráter permanente. Uma vez formado o partido, as próximas convenções serão convocadas pelos diretórios constituídos.

\footnotetext{
${ }^{19} \mathrm{O}$ instituto das comissões provisórias foi criado pela Lei Orgânica dos Partidos de 1971, a mesma legislação que criou as bancadas partidárias. O intuito da Lei era permitir que os dois partidos que existiam pudessem oferecer candidatos em todo o país mesmo nas localidades onde ainda não haviam diretórios.
} 
Assim, na origem do partido temos uma situação precária e pouco institucionalizada, na qual quem determina as regras e escolhe os dirigentes é uma pequena parcela de pessoas que forma a Comissão Provisória Executiva Nacional (CPEN). Teoricamente, passado um ano, o partido entraria em sua forma organizada funcionando conforme descrito mais acima com chapas concorrendo pelo voto de membros das convenções partidárias e essas convenções decidindo quem serão os futuros dirigentes.

Seria de se esperar que todos os partidos analisados estivessem organizados em diretórios, pois, na sua grande maioria, foram criados no começo dos anos 80 . No entanto, e essa é uma das constatações mais interessantes do trabalho, uma grande parte dos partidos ainda funciona como se estivesse no momento de origem, isto é, ainda se constituem, no todo ou em grande parte, como comissões provisórias. As implicações disto para o controle partidário são claras: os dirigentes nacionais detêm, nestes partidos, o controle total sobre as decisões partidárias. Estaríamos diante de monocracias ou, no máximo, de oligarquias, na concepção de Panebianco.

A Tabela 2.2 mostra como os partidos pesquisados estão organizados pelos municípios em uma amostra de estados brasileiros ${ }^{20}$. Ela mostra, por exemplo, que o PTB é o que possui o maior número de comissões provisórias, são 2.301 em um total de 2.550 municípios em que está presente (90\%). Já o PT é o partido que possui a menor proporção de comissões provisórias, são 515 municípios em 2.651 (19\%).

\footnotetext{
${ }^{20}$ Os estados analisados são Acre, Amapá, Distrito Federal, Minas Gerais, Mato Grosso do Sul, Pernambuco, Rio de Janeiro, Rondônia, Roraima, Rio Grande do Sul, Roraima, Santa Catarina e São Paulo. Esses estados forma escolhidos por serem aqueles para os quais existiam informações sobre a situação dos órgãos partidários no nível municipal.
} 
TABELA 2.2 - DISTRIBUIÇÃO DOS PARTIDOS CONFORME SITUAÇÃO DO ÓRGÃO PARTIDÁRIO MUNICIPAL

\begin{tabular}{|c|c|c|c|c|c|c|c|}
\hline & & & & & & & \\
\hline & PT & PDT & PSDB & PMDB & PTB & DEM & PP \\
\hline Municípios & 2.651 & 2.300 & 2.571 & 2.675 & 2.550 & 2.479 & 2.363 \\
\hline Diretórios & 2.136 & 976 & 1.722 & 2.128 & 249 & 876 & 916 \\
\hline Comissões Provisórias (CPs) & 515 & 1.324 & 839 & 763 & 2.301 & 1.603 & 1.347 \\
\hline CPs/Municípios & 0,19 & 0,58 & 0,33 & 0,29 & 0,90 & 0,65 & 0,57 \\
\hline
\end{tabular}

Fonte: TRE's - 2007 e 2008

Observando a situação dos órgãos partidários nos municípios por estado vemos que mesmo partidos com baixo número de comissões provisórias tomadas agregadamente podem possuir altas proporções destas comissões no nível regional, conforme Tabela 2.3.

TABELA 2.3 - DISTRIBUIÇÃO DOS PARTIDOS CONFORME PROPORÇÃO DE COMISSÕES PROVISÓRIAS POR ESTADO

\begin{tabular}{lrrrrrrr} 
& PT & PDT & PMDB & PSDB & PTB & DEM & PP \\
\hline AC & $0 \%$ & & $44 \%$ & $77 \%$ & & $100 \%$ & $100 \%$ \\
AP & $6 \%$ & $31 \%$ & $14 \%$ & $50 \%$ & $83 \%$ & $92 \%$ & $80 \%$ \\
MG & $6 \%$ & $68 \%$ & $37 \%$ & $46 \%$ & $80 \%$ & $40 \%$ & $100 \%$ \\
MS & $4 \%$ & $26 \%$ & $6 \%$ & $31 \%$ & $69 \%$ & $68 \%$ & $70 \%$ \\
PE & $17 \%$ & $99 \%$ & $70 \%$ & $82 \%$ & $76 \%$ & $86 \%$ & $100 \%$ \\
RJ & $13 \%$ & $79 \%$ & $23 \%$ & $14 \%$ & $98 \%$ & $87 \%$ & $73 \%$ \\
RO & $12 \%$ & $64 \%$ & $25 \%$ & $68 \%$ & $79 \%$ & $98 \%$ & $65 \%$ \\
RS & $22 \%$ & $11 \%$ & $2 \%$ & $17 \%$ & $99 \%$ & $69 \%$ & $5 \%$ \\
RR & $33 \%$ & $100 \%$ & $100 \%$ & $67 \%$ & $100 \%$ & $64 \%$ & $100 \%$ \\
SC & $24 \%$ & $65 \%$ & $1 \%$ & $6 \%$ & $99 \%$ & $27 \%$ & $19 \%$ \\
SP & $36 \%$ & $72 \%$ & $8 \%$ & $23 \%$ & $100 \%$ & $100 \%$ & $71 \%$ \\
\hline \hline
\end{tabular}

Fonte: TSE e TRE's

Obs.: A proporção se refere ao número de comissões provisórias sobre o total de municípios em cada estado considerado.

A Tabela acima traz algumas informações interessantes. O PT tem aproximadamente $100 \%$ de diretórios em quase todos os estados com exceção daqueles em que ele é mais forte como São Paulo (64\%) e Rio Grande do Sul (78\%). Esses dois estados são berços do grupo dos sindicalistas que fundaram e organizaram o partido e, por isso, pode parecer paradoxal o fato do partido ser menos organizados justamente nestes estados. No entanto, como 
veremos mais à frente, existe uma associação entre a presença de comissões provisórias e o poder na organização.

O PDT apresenta pequena proporção de diretórios no Rio de Janeiro, estado de seu líder máximo Leonel Brizola, mas é extremamente organizado no Rio Grande do Sul, antigo reduto brizolista. O PSDB também apresenta diferenças de organização com é o caso de São Paulo e Minas Gerais que retomaremos mais à frente. O DEM só é fortemente organizado em Santa Catarina, lar de seu presidente Jorge Bornhausen.

Já o PP só está organizado massiçamente em diretórios em dois estados, Rio Grande do Sul e Santa Catarina, estados onde o partido exerceu poder. A proporção de comissões provisórias sobre o número de municípios em que está presente, $57 \%$ conforme a Tabela 2.1, esconde o fato de que, fora destes dois estados, ele está amplamente baseado em uma estrutura precária. Mesmo em São Paulo, base importante do partido, as comissões provisórias perfazem $71 \%$ dos órgãos municipais do partido.

No nível regional a situação dos órgãos partidários não é diferente da do nível municipal como mostram as Tabela 2.4. Mesmo neste nível existem partidos que funcionam de forma provisória, sendo que o maior destaque vai para o PTB onde $73 \%$ das organizações regionais são comissões provisórias.

TABELA 2.4 - DISTRIBUIÇÃO DOS PARTIDOS CONFORME SITUAÇÃO DO ÓRGÃO PARTIDÁRIO REGIONAL

\begin{tabular}{lrrrrrrrr} 
& PT & & PDT & PMDB & PSDB & PTB & DEM & PP \\
CP & 0 & 9 & 0 & 0 & 14 & 9 & 5 \\
DIR & 21 & 11 & 21 & 21 & 5 & 12 & 15 \\
Total & 21 & 20 & 21 & 21 & 19 & 21 & 20 \\
\hline \hline
\end{tabular}

Fonte: TSE e TRES 


\section{Uma tipologia das organizações partidárias brasileiras}

Retomando o exposto até aqui vimos que, para entender como as lideranças controlam as decisões partidárias, era necessário entender como se dava o processo de escolha de dirigentes nos partidos. Vimos que esse processo está baseado nas convenções partidárias e que, por extensão, quem controla as convenções controla o partido. Vimos que as lideranças possuem mecanismos, notadamente as comissões provisórias, para controlar as convenções e vimos, por fim, que os partidos se dividem em dois modos pelos quais as lideranças controlam a convenção: de um lado temos partidos onde uma direção coesa utiliza as comissões provisórias para ter um controle quase absoluto das decisões do partido e, de outro lado, temos partidos em que as lideranças, por estarem elas mesmas divididas, não conseguem utilizar a dissolução de diretórios e a criação de comissões provisórias como arma e têm que se submeter à incerteza do jogo democrático.

Essa diferença permite classificar os partidos em um contínuo que vai do PT, o partido mais descentralizado, até o PTB, o mais centralizado, conforme a Tabela 2.6.

TABELA 2.5 - CLASSIFICAÇÃO DOS PARTIDOS CONFORME A PROPORÇÃO DE COMISSÕES PROVISÓRIAS

\begin{tabular}{ccccccc}
\hline PT & PMDB & PSDB & PP & PDT & DEM & PTB \\
0,19 & 0,29 & 0,33 & 0,57 & 0,58 & 0,65 & 0,90 \\
\hline
\end{tabular}

Nesta Tabela vemos que também é possível distinguir três tipos de partidos: partidos onde há um terço ou menos de comissões provisórias e que poderíamos considerar como partidos organizados (PT, PMDB, PSDB). Partidos onde o número de comissões provisórias se aproxima do número de diretórios permanentes e que, portanto, consideraríamos como de 
organização mista (PP, PDT e DEM). Partidos quase totalmente dominados por comissões provisórias, que iremos considerar partidos não organizados (PTB).

QUADRO 2.1 - CLASSIFICAÇÃO DOS PARTIDOS CONFORME SEU GRAU DE DESENVOLVIMENTO ORGANIZACIONAL

\begin{tabular}{|l|l|l|}
\hline $\begin{array}{l}\text { Organizados/Poliárquic } \\
\text { os }\end{array}$ & $\begin{array}{l}\text { De organização } \\
\text { mista/Oligárquicos }\end{array}$ & $\begin{array}{l}\text { Não } \\
\text { organizados/Monocráticos }\end{array}$ \\
\hline PT, PMDB, PSDB & PDT, PP, DEM & PTB \\
\hline
\end{tabular}

Para manter a terminologia sugerida por Panebianco e nos fixarmos no duplo critério centralização/descentralização, chamaremos o primeiro bloco de partidos poliárquicos, o segundo bloco de partidos oligárquicos e o terceiro bloco de partidos monocráticos. No caso dos partidos poliárquicos a organização em diretórios faz com que as lideranças tenham que estabelecer constantes negociações no interior do partido para garantir o controle do processo de decisão e tanto a coesão quanto a estabilidade da coalizão dirigente são precárias. No caso dos partidos oligárquicos, a direção partidária está dividida em poucos grupos, um grupo sozinho não pode controlar o partido, mas o pequeno número deles permite a coesão e a estabilidade da coalizão ${ }^{21}$. No caso dos partidos monocráticos a liderança está nas mãos de um só grupo que tem absoluto controle sobre as decisões partidárias.

Conforme Panebianco essas conformações partidárias se devem ao modo como se iniciou e desenvolveu a construção da organização partidária. Segundo este autor:

\footnotetext{
${ }^{21}$ Embora o PDT de Brizola girasse em torno da figura de seu líder máximo ele sozinho não conseguiria controlar o partido. Brizola, nos seus planos de se tornar presidente, precisava de bases fortes em outros estados que não o Rio de Janeiro ou o Rio Grande do Sul. Para isso teve que admitir outros poucos líderes expressivos no partido o que, como veremos no capítulo 4, gerou alguns conflitos.
} 
“... o desenvolvimento organizativo de um partido - a construção da organização em sentido estrito - pode ocorrer ou por penetração territorial, ou por difusão territorial, ou por uma combinação de ambas as modalidades. Há penetração territorial quando um 'centro' controla, estimula e dirige o desenvolvimento da 'periferia' (...) Há difusão territorial quando o desenvolvimento se dá por 'germinação' espontânea: são as elites locais que, num primeiro momento, constroem as associações partidárias e somente depois essas associações são integradas em uma organização nacional” (PANEBIANCO 2003, pg. 94)

O número de diretórios constituídos dá uma idéia da estratégia de organização adotada pela direção no momento de origem do partido. Veremos com mais detalhes no Capítulo 5 que o PMDB, o PT e o PSDB, se aproximam do tipo de desenvolvimento por difusão, no caso dos dois primeiros e misto, no caso do terceiro, o que ajuda a explicar a o fato desses partidos possuírem o maior número de diretórios constituídos. Já o DEM, PTB, PDT e PP adotaram o tipo de desenvolvimento por penetração, esses são partidos de força localizada e que mantêm o desenvolvimento do partido sob controle estrito.

O tipo de desenvolvimento tem implicações para a coesão organizativa. Partidos que se desenvolvem por penetração têm uma coalizão dominante coesa desde o início. Partidos que se desenvolvem por difusão têm maiores dificuldades no processo de formação de lideranças e uma coalizão dominante dividida entre líderes que controlam o partido no nível local e que podem aspirar à liderança nacional. 
Além do tipo de desenvolvimento organizacional, a presença de diretórios indica o grau de sistemicidade dos partidos, para utilizar outro termo de Panebianco ${ }^{22}$. O grau de sistemicidade se relaciona com o grau de autonomia das subunidades do partido com relação à direção central. Um alto grau de sistemicidade indica que as subunidades têm pouca autonomia, este é o caso dos partidos onde imperam as comissões provisórias.

Assim, vemos que uma forte presença de comissões provisórias indica que um partido se desenvolveu por um processo de penetração e que este partido possui grande sistemicidade o que, recorrendo mais uma vez à tipologia de Panebianco, caracterizaria um partido forte. Pela nossa definição, segundo a qual um partido é forte quando sua direção controla as decisões estratégicas do partido, a presença de comissões provisórias também indica maior força. Voltaremos a isso quando examinarmos os casos específicos.

\section{O uso estratégico das Comissões Provisórias}

O instituto das comissões provisórias existe para garantir a presença do partido naqueles locais onde ele ainda não conseguiu estabelecer uma estrutura, onde ele está começando a atuar. No entanto, o fato de partidos com mais de uma década de funcionamento e mais de

\footnotetext{
${ }^{22}$ Para Panebianco os partidos se diferenciam pelo grau de institucionalização. Esse grau pode ser medido pelos parâmetros "autonomia com relação ao ambiente externo" e "sistemicidade (autonomia das subunidades)". Esses dois parâmetros são utilizados por apresentarem deslocamentos na mesma direção, isto é, quanto mais autônomo um partido maior sua sistemicidade ao contrário do que ocorre com o conceito de institucionalização utilizado por Huntington onde os parâmetros "autonomia", "coerência", "complexidade" e "flexibilidade" não caminham necessariamente na mesma direção, o que impede a sua utilização simultânea na construção de um índice. Esses parâmetros são combinados com os fatores do modelo original para definir a força institucional do partido, assim, por exemplo, partidos que se desenvolveram por penetração territorial e que apresentam elevado grau de sistemicidade seriam fortemente institucionalizados.
} 
um milhão de filiados ainda manterem alta proporção de comissões provisórias são indícios de que elas são utilizadas de forma estratégica pela direção partidária.

As lideranças partidárias podem utilizar a ausência de organização para dominar discricionariamente a organização partidária. Panebianco mostra como, no caso dos partidos monocráticos, a coesão e estabilidade da coalizão dominante pode ser fruto da ausência da institucionalização. No caso do Partido Nazista, Niomarkay, citado em Panebianco, afirma que:

A técnica de Hitler para manter um controle total sobre o partido consistia em impedir a formação de 'regras': a aversão de Hitler pelas regras e sua insistência por uma autoridade incondicional da sua vontade impediram a organização do partido baseada em princípios burocráticos (...). Ele compreendeu corretamente que qualquer ordem burocrática, seja qual for o seu grau de autoritarismo, limita o poder arbitrário e oferece alguma proteção aos subordinados (Panebianco, 2005:301).

Se estivermos certos e as lideranças dos partidos oligárquicos e monocráticos estiverem utilizando de forma estratégica o caráter provisório desses partidos elas deveriam ser mais estáveis do que as lideranças dos partidos poliárquicos. Daí as hipóteses seguintes:

H1: as coalizões dirigentes de partidos organizados por meio de comissões provisórias garantem seu domínio por mais tempo.

H2: as coalizões dirigentes em partidos estruturados em diretórios são menos estáveis.

Seguindo Panebianco vamos considerar uma coalizão dirigente estável aquela que pratica “acordos relativamente duradouros na repartição das esferas de influência no interior da 
organização" (PANEBIANCO, 2005:324). Esses acordos duradouros se revelam na capacidade da coalizão dirigente manter em suas mãos os cargos chave de poder no interior do partido.

Ao observarmos o tempo em que um político ocupou a presidência nos sete maiores partidos brasileiros constatamos, em primeiro lugar, que em apenas três casos um presidente saiu antes do fim de seu mandato: Ricardo Berzoini, do PT, em 2006, Jader Barbalho, do PMDB, em 2001, e Roberto Jefferson, do PTB em 2005. No entanto em nenhum destes casos foram as disputas internas que motivaram a renúncia, mas sim escândalos políticos que, ao envolverem estes políticos, acabaram por inviabilizar sua permanência no cargo. Tanto Berzoini quanto Jefferson voltaram à presidência de seus partidos.

O PT teve Luis Inácio Lula da Silva como presidente durante seus primeiros 15 anos de vida, de 1980 a 1995, com apenas dois anos de interrupção quando Lula se dedicou ao seu mandato de deputado federal constituinte e à sua primeira campanha eleitoral. Lula foi sucedido por José Dirceu, do mesmo grupo político dentro do PT, a Articulação mais tarde conhecida como Campo Majoritário, que exerceu o cargo de 1995 a 2002 quando deixa o partido nas mãos de José Genuíno, também da Articulação/Campo majoritário.

O PDT foi presidido, de sua origem em 1980 até 2004, por Leonel Brizola. Em 2004 Brizola faleceu e foi sucedido por Carlos Luppi que sempre ocupou cargos na executiva nacional como os de secretario geral e tesoureiro.

A história do PMDB é mais conturbada do que a dos outros partidos, como veremos com mais detalhes no Capítulo 5. Durante 12 anos, de 1979 a 1991, ele foi presidido por Ulysses 
Guimarães falecido em 1992. Entre 1991 e 2001 há sucessão de grupos adversários no poder, cada grupo permanecendo em média três anos, até que, em 2001, Michel Temer assume a legenda permanecendo no cargo até o presente.

O PSDB, onde a reeleição para o mesmo cargo na Comissão Executiva só pode ser feita uma vez, teve o maior número de presidentes entre os partidos analisados. Foram nove presidentes ao todo e apenas dois deles exerceram mais de um mandato: Tasso Jereissati (1991 - 1994 e 2005 - 2007) e Teotônio Vilela Filho (1996 - 2001). Todos os presidentes do partido fazem parte do mesmo grupo que o fundou em 1988 e as sucessões ocorrem sem conflito.

O PTB é um caso curioso. Este partido teve seis presidentes plenos e um "tampão". Quatro dos presidentes plenos morreram no exercício do mandato. José Eduardo Andrade Vieira permaneceu a frente do partido entre 1994 e 1999 quando decidiu deixar a política. Roberto Jefferson assumiu o partido em 2003 após a morte de José Carlos Martinez e permanece no seu comando até hoje com uma breve interrupção em 2005 quando foi protagonista de um escândalo de corrupção nos Correios e se tornou o pivot do escândalo do "mensalão".

No PFL o trio que fundou o partido, Jorge Bornhausen, Guilherme Palmeira e Marco Maciel se sucederam na sua presidência que contou também com Hugo Napoleão. Bornhausen ocupou a presidência por 14 anos, de 1985 a 1986 e de 1993 a 2007. Em 2007 o PFL muda de nome para Democratas e entrega seu comando para uma nova geração com Rodrigo Maia, filho do então prefeito do Rio de Janeiro César Maia, na presidência.

O PP, ex-PDS, teve apenas 3 presidentes plenos sendo que Paulo Maluf presidiu o partido por 14 anos, de 1985 a 1993 e de 1997 a 2003. Neste período a presidência de Maluf só foi 
interrompida para que ele exercesse seu mandato de prefeito de São Paulo, ocasião em que o cargo foi ocupado por Esperidião Amim, aliado de longa data. Em 2003, com seu nome envolvido em grandes escândalos de corrupção, Maluf deixa a presidência do partido que, visando melhorar sua imagem, muda seu nome para PP. Maluf assume a Presidência de Honra com assento na comissão executiva nacional, mas já sem o mesmo poder de antes.

Vemos assim que em todos os partidos as coalizões dirigentes são estáveis. Vemos também que, em geral, a coalizão dominante no momento de fundação do partido se perpetua no seu controle. Casos de alternância no poder por disputas internas só ocorrem no PMDB. Em todos os outros partidos a sucessão se dá ou por norma estatutária, como no PSDB, ou por renúncia devido a escândalos, caso do PT, PTB e PP, ou por morte, como no PDT e PTB. Em todos estes casos, no entanto, não houve ruptura na coalizão dirigente.

Resta saber se o fato de um partido ter mais ou menos comissões provisórias influencia de algum modo o tempo de permanência de um líder na sua presidência, isto é, se as diferenças no modo como o partido se organiza influi na estabilidade da coalizão dirigente. Para verificar se há correlação entre essas duas variáveis iremos definir como taxa de permanência a quantidade de anos em que o partido foi liderado pelo presidente que permaneceu mais tempo à frente da legenda sobre o total de anos de existência daquele partido. A taxa de permanência pode ser entendida como o máximo de tempo que um líder pode esperar estar à frente de um partido. A variável organização partidária é definida 
como a quantidade de comissões provisórias sobre o total de municípios ${ }^{23}$. A Tabela 2.7, abaixo, apresenta os resultados.

TABELA 2.6- TAXA DE PERMANÊNCIA DE DIRIGENTES PARTIDÁRIOS NOS SETE MAIORES PARTIDOS BRASILEIROS.

\begin{tabular}{|c|c|c|}
\hline Partido & $\begin{array}{l}\text { Taxa } \\
\text { Permanência }\end{array}$ & $\begin{array}{l}\text { Proporção de } \\
\text { Comissões } \\
\text { Provisórias }\end{array}$ \\
\hline PSDB & 0,29 & 0,33 \\
\hline PT & 0,46 & 0,19 \\
\hline PMDB & 0,56 & 0,29 \\
\hline PP & 0,65 & 0,57 \\
\hline PFL & 0,67 & 0,65 \\
\hline PDT & 0,92 & 0,58 \\
\hline
\end{tabular}

A Tabela 2.7 permite constatar que quanto maior a proporção de comissões provisórias maior a taxa de permanência (coeficiente de correlação de 0,70 ). Isso estaria de acordo com a Hipótese 1. Este quadro também nos mostra que, com a exceção do PSDB, todos os partidos tiveram um mesmo presidente em metade ou mais de sua existência, o que mostra a estabilidade das lideranças no sistema partidário como um todo, no entanto a taxa de permanência média dos partidos organizados (PT, PMDB e PSDB) é de 44\% enquanto a taxa de permanência média dos partidos de organização mista (PP, PFL e PDT) é de $75 \%{ }^{24}$, isto é, um líder pode se manter mais tempo na presidência nos partidos de organização mista do que nos partidos organizados ${ }^{25}$, o que está de acordo com a Hipótese 2.

Essas constatações sugerem que o caráter provisório dos partidos traz vantagem para suas lideranças, o que indica o uso estratégico da falta de regras. Isso fica claro no

\footnotetext{
${ }^{23}$ Conforme Tabela 2.1 apresentada na página 50.

${ }^{24}$ O PTB é um caso a parte já que uma grande parte de seus presidentes morreu no exercício do mandato. Praticamente não há alternância no PTB, mas é difícil calcular uma taxa de permanência para este partido. ${ }^{25} \mathrm{Um}$ teste qui-quadrado mostra que um diferença igual ou superior a esta ocorre com uma probabilidade de 0,0027 .
} 
pronunciamento de Aloysio Nunes Ferreira, uma dessas lideranças partidárias, na Comissão de Constituição e Justiça e de Cidadania da Câmara dos Deputados em junho de 2004:

Observem V.Exas. que alguns partidos, exatamente os que são contra essas propostas (de reforma política) — basicamente o PL, o PTB e o PP —, alegam que isso levaria à oligarquização da vida política. Ora, são oligarquias esses partidos, essa é a realidade. Na grande maioria dos Estados, esses partidos não têm organização definitiva, são comissões provisórias. Nos Municípios, são comissões provisórias, são de propriedade de alguns Parlamentares, que alteram essas comissões provisórias a seu bel-prazer, para manter o seu poder dentro do partido. São exatamente esses partidos que argumentam com maior vigor contra a oligarquização. Evidentemente, não interessa a essas oligarquias atuais que o sistema partidário seja vivificado, com a maior participação dos cidadãos no partido político. E esses partidos compõem a base do Governo. É uma realidade.

O que muitas vezes é visto pela ciência política e pela crítica em geral como indício de subdesenvolvimento político é a fonte da força de alguns partidos e, como veremos no capítulo 3, é o que garante a coordenação e estabilidade do sistema partidário.

\section{Conclusão}

Esse capítulo procurou preencher uma lacuna na literatura da ciência política brasileira ao investigar na organização partidária como se dá o processo de tomada de decisão no interior dos partidos. Mostramos que, ao contrário da visão dominante, há vida partidária no Brasil e que essa vida gira em torno do controle das decisões partidárias. 
O controle sobre as decisões partidárias se dá a partir do controle sobre as convenções. Embora formalmente as convenções sejam controladas da base para o topo na prática as lideranças têm mecanismos que lhes permite controlar de fato o processo. Esse controle irá variar conforme a liderança partidária seja mais ou menos coesa.

A coesão da liderança ou, conforme Panebianco, da coalizão dominante, depende do modo como os partidos se constituíram. Partidos que nasceram por difusão tendem a ter estruturas locais permanentes com suas lideranças próprias e são mais divididas. Partidos que surgiram por penetração tendem a se constituir por meio de comissões provisória com lideranças locais escolhidas pela direção central que é mais coesa.

Em média, a liderança de um partido estruturado em comissões provisórias permanece $30 \%$ a mais de tempo no comando da legenda, o que indica o uso estratégico da baixa organização. O uso estratégico das comissões provisórias garante um enorme poder e maior estabilidade para as lideranças. Essas lideranças têm controle sobre as "zonas de incerteza" dos partidos e, deste modo, têm controle sobre o comportamento e o destino de seus membros.

Assim a proporção de comissões provisórias em um partido pode ser utilizada como proxy do grau de centralização do poder no interior do partido, quanto mais comissões provisórias tem um partido maior o controle que as lideranças possuem sobre as decisões partidárias. A partir deste critério teríamos três tipos de partidos conforme a proporção de comissões provisórias: partidos poliárquicos organizados (PT, PSDB e PMDB), partidos oligárquicos de organização mista (PP, PDT e DEM) e partidos monocráticos não organizados (PTB). 
Essa tipologia supera a dicotomia presente na literatura corrente que contrapõe os partidos de massa organizados e capazes de impor disciplina a seus membros aos partidos não institucionalizados altamente fragmentados e baseados em vínculos pessoais. Vimos, examinando as regras partidárias e veremos novamente no Capítulo 5 quando examinarmos mais detalhadamente os diversos tipos de organização, que esses dois tipos ideais não resistem a um exame que incorpore a organização partidária como variável. No Brasil os partidos mais organizados não são necessariamente os mais coesos e os partidos menos organizados são aqueles onde as lideranças têm maior poder.

Se os partidos se diferenciam quanto ao controle que as lideranças exercem sobre sua organização e sobre as decisões estratégicas, isso deve ter algum impacto sobre o sistema partidário. Defenderemos, no Capítulo 4, a tese de que a concentração do poder no interior da organização partidária afeta o número de partidos que entram na disputa eleitoral. Assim a concentração do poder no interior do partido ajudaria a explicar a coordenação préeleitoral entre as elites políticas.

Antes de testarmos a hipótese delineada acima iremos, no próximo capítulo, examinar a literatura sobre os fatores que explicam o número de partidos em um dado sistema. Veremos que esta literatura gira em torno da chamada Lei de Duverger que afirma que o voto estratégico e a antecipação por parte das lideranças deste voto reduziriam o número de partidos que participam de uma disputa eleitoral. O principal objetivo do capítulo será testar os efeitos da Lei de Duverger nas eleições majoritárias brasileiras. 


\section{CAPÍTULO 3 - VOTO ESTRATÉGICO E COORDENAÇÃO ELEITORAL NO BRASIL}

\section{Introdução}

No capítulo anterior preenchemos uma lacuna nos estudos sobre os partidos brasileiros examinando mais de perto como esses partidos funcionam. Mostramos que a tese de que não há vida partidária no Brasil e de que os partidos brasileiros são fracos precisava ser revista. Neste capítulo pretendemos preencher outra lacuna: são poucos os estudos que tratam de eleições majoritárias tentando entender o que determina o número de partidos em uma disputa, principal característica definidora de um sistema partidário. Essa lacuna é de se estranhar devido ao volume de trabalhos sobre o tema produzido em outros países e a relevância dos pesquisadores que se dedicam a ele.

A falta de estudos sistemáticos sobre o número de partidos se deve ao fato de que os estudos que investigam o sistema partidário brasileiro que se instaura no Brasil a partir de 1980 dão privilégio às eleições parlamentares que ocorrem sob o sistema de representação proporcional (LIMA JR., 1997). Na representação proporcional os custos de entrada nas disputas eleitorais são baixos e, portanto, os mecanismos clássicos identificados pela literatura para reduzir o número de partidos não operam. Elites políticas e eleitores não teriam porque coordenar suas estratégias/votos.

As eleições majoritárias, ao contrário, envolvem poucas cadeiras e têm custos de entrada elevados o que, de acordo com a tese de Duverger, limitaria o número de partidos na 
disputa. O mecanismo pelo qual isto ocorre é captado pela conhecida Lei de Duverger.

Durante mais de 50 anos as proposições de Duverger foram criticadas, estendidas e testadas por inúmeros pesquisadores em diversos países. No entanto, surpreendentemente, no Brasil este debate teve pequena repercussão, sobretudo no que tange às eleições majoritárias ${ }^{26}$.

Como vimos nos capítulos anteriores, a Ciência Política brasileira, ao seguir o que Peres (2002) chama de orientação huntington-sartoriana, traçou um diagnóstico pessimista quanto ao futuro da democracia brasileira. A causa do mal é a elevada fragmentação partidária e a prevalência dos vínculos pessoais em detrimento dos vínculos partidários. A seguinte passagem, retirada de Kinzo (1993) faz uma síntese desta perspectiva:

Embora os dados de que dispomos sejam insuficientes para este tipo de avaliação, parece que o sistema partidário ora em formação tem condições sobretudo se dispositivos legais inibidores da fragmentação forem estabelecidos - de se consolidar como um pluripartidarismo moderado e não polarizado ou radicalizado, entre esquerda e direita. Se esta hipótese for plausível, o futuro não precisa ser visto com excessivo pessimismo. A redução da fragmentação também pode ocorrer mediante um processo espontâneo de aglutinação. Posições não polarizadas podem facilitar a aproximação entre partidos diferenciados, mas não antagônicos. Em suma, a configuração que se está delineando deixa espaço para uma intervenção legislativa que, mantendo o desejável pluralismo, torne-o moderado e reduza a excessiva fragmentação atualmente existente (KINZO, 1993:85)

\footnotetext{
${ }^{26}$ Jairo Nicolau e Rogério Schmitt são alguns dos poucos autores que apontam as relações entre a Lei de Duverger e o debate sobre o número de partidos (SCHMITT e NICOLAU, 1995).
} 
Como veremos a seguir essa "excessiva fragmentação" encontrada nas disputas para o legislativo não se reproduz nas eleições majoritárias. Nestas eleições o número efetivo de partidos é reduzido tanto pelos efeitos do voto estratégico quanto pela coordenação préeleitoral.

\section{1 - A Lei de Duverger e suas extensões.}

O modo convencional de se descrever um sistema partidário é a partir do número de partidos. A distinção básica é entre sistemas bipartidários e sistemas com mais de dois partidos (DUVERGER 1970). Para Duverger, o bipartidarismo apresentava um caráter natural, pois as questões políticas se apresentam sob forma dualista, mais ainda "o movimento natural das sociedades orienta-se para o bipartidarismo, podendo, evidentemente, ser contrariado por tendências inversas" (DUVERGER, 1970:252) ${ }^{27}$.

As tendências inversas que levam ao multipartidarismo seriam o "sinistrismo" e a sobreposição de dualismos. O "sinistrismo" se dá quando um partido de centro assume o governo e perde uma ala mais à esquerda contrariada com a moderação que o partido adota. Essa facção à esquerda forma um novo partido que, sendo bem sucedido eleitoralmente acaba por tomar medidas moderadas perdendo também sua facção mais à esquerda. Isso aconteceria sucessivamente gerando uma miríade de partidos.

\footnotetext{
${ }^{27}$ Nesta visão não há centro em política, apesar de poderem existir partidos de centro estes partidos na verdade são meros "agrupamentos artificiais da parte direita da esquerda e da parte esquerda da direita" (DUVERGER:251).
} 
A sobreposição de dualismos ocorre quando a política se dá em várias dimensões surgindo várias dualidades nas quais diferentes partidos assumem suas posições. Assim, países onde a questão religiosa tem importância poderiam ter quatro partidos, dois partidos que se posicionassem nos extremos da dimensão econômica conservador/liberal e outros dois partidos que se posicionassem nos extremos da dimensão secular/religioso.

Essa distinção entre dois e vários partidos e o caráter natural atribuído ao bipartidarismo permitiu que se associasse estabilidade democrática ao número de partidos. Conforme Mair:

Thus two party systems, which were typically characteristic of the United Kingdom and the United States, and which invariably involved single-party government, were assumed to enhance accountability, alternation in government, and moderate, centre-seeking competition. Multiparty systems, on the other hand, which usually required coalition administration, and which were typically characteristic of countries such as France or Italy, prevented voters from gaining a direct voice in the formation of governments, did not facilitate alternation in government, and sometimes favored extremist, ideological confrontations between narrowly based political parties (MAIR, 1997:200)

A partir desta primeira distinção elaborada por Duverger surgiram outras como a de Blondel que, além do número de partidos levava em conta o tamanho relativo destes partidos. Blondel (1982) distingue quatro tipos de sistemas partidários: sistemas de dois partidos, sistemas de dois partidos e meio, sistemas multipartidários com um partido dominante e sistemas multipartidários sem partidos dominantes. 
Stein Rokkan também estende o trabalho de Duverger e distingue categorias de multipartidarismo. Rokkan (1987) leva em conta a possibilidade da ocorrência de partidos majoritários (equivalente ao multipartidarismo de partido dominante de Blondel) e a fragmentação dos partidos minoritários. O autor distingue três tipos de sistemas partidários. O primeiro tipo é o sistema "britânico-germânico" no qual há a competição entre dois grandes partidos com um terceiro partido minoritário também presente na disputa. $\mathrm{O}$ segundo tipo é o "escandinavo" onde um partido grande disputa com uma aliança entre três ou quatro pequenos partidos. O terceiro tipo de sistema partidário é o sistema "equilibrado", onde três ou mais partidos de tamanho equivalente participam da disputa. A tipologia mais influente é a de Giovanni Sartori. Sartori (1982) aperfeiçoa o modelo de Duverger fazendo uma distinção entre polaridade e polarização, isto é, entre o número de partidos e a distância ideológica entre os partidos. Esses dois critérios não seriam independentes e sistemas multipartidários tenderiam à maior polarização. Essa distinção permitiu a Sartori classificar os sistemas partidários em sistemas de dois partidos, sistemas com até cinco partidos moderados (pluralismo moderado), sistemas com seis ou mais partidos polarizados (pluralismo polarizado) e sistemas de partidos predominantes. ${ }^{28}$ O quadro abaixo resume estas diferentes classificações dos sistemas partidários.

\footnotetext{
${ }^{28}$ Assim como em Blondel, para Sartori importa os partidos relevantes, neste caso partidos capazes de constituir uma coalizão.
} 
QUADRO 3.1 - CLASSIFICAÇÃO DE SISTEMAS PARTIDÁRIOS

\begin{tabular}{|c|c|c|}
\hline Autor & $\begin{array}{l}\text { Principal critério de } \\
\text { classificação }\end{array}$ & $\begin{array}{l}\text { Principais tipos de sistemas partidários } \\
\text { identificados }\end{array}$ \\
\hline Duverger & Número de partidos & $\begin{array}{l}\text { Sistemas de dois partidos } \\
\text { Sistemas multipartidários }\end{array}$ \\
\hline Blondel & $\begin{array}{l}\text { Número de partidos } \\
\text { Tamanho relativo dos } \\
\text { partidos }\end{array}$ & $\begin{array}{l}\text { Sistemas de dois partidos } \\
\text { Sistemas de dois partidos e meio } \\
\text { Sistemas multipartidários com um } \\
\text { partido dominante } \\
\text { Sistemas multipartidários sem partidos } \\
\text { dominantes }\end{array}$ \\
\hline Rokkan & $\begin{array}{l}\text { Número de partidos } \\
\text { Possibilidade de um partido } \\
\text { majoritário } \\
\text { Distribuição da força dos } \\
\text { partidos minoritários }\end{array}$ & $\begin{array}{l}\text { "Britânico - Germânico" (1 X 1) + } 1 \\
\text { "Escandinavo" } 1 \text { X } 3 \text { ou } 4 \\
\text { "Equilibrado" ( } 1 \text { X } 1 \text { X } 1)+2 \text { ou } 3\end{array}$ \\
\hline Sartori & $\begin{array}{l}\text { Número de partidos } \\
\text { Distância ideológica }\end{array}$ & $\begin{array}{l}\text { Sistemas de dois partidos } \\
\text { Pluralismo moderado } \\
\text { Pluralismo polarizado } \\
\text { Sistema de partidos dominantes }\end{array}$ \\
\hline
\end{tabular}

Extraído de Mair (1997:202)

Dada a importância do número de partidos em um sistema, inúmeros autores se dedicaram a entender que fatores levam ao bipartidarismo ou às várias formas de multipartidarismo. Os principais fatores que influiriam no número de partidos seriam de natureza socioeconômica, ideológica e técnica. São os fatores técnicos que serão analisados por Duverger. Para ele o bipartidarismo apresenta um caráter natural, isto é, as opções políticas se apresentariam sempre sob forma dualista, que se refletem ou não em organizações partidárias. A questão para Duverger é entender porque esse caráter natural se revela em países como Inglaterra e não em países como a França. A resposta estaria em um fator geral de ordem técnica: o sistema eleitoral.

A associação que Duverger faz dessas duas variáveis ficou conhecida como Lei de Duverger: "o escrutínio majoritário de um só turno tende ao dualismo dos partidos" e, pelo 
contrário, "o escrutínio majoritário de dois turnos ou a representação proporcional tendem ao multipartidarismo" (o que será chamada por Riker de "a hipótese de Duverger").

A ação destes fatores é descrita por Duverger nos seguintes termos:

O mecanismo dessa ação é muito simples: por exemplo, uma circunscrição britânica onde os conservadores têm 35.000 votos, os trabalhistas 40.000 e os liberais 15.000. É claro que o sucesso trabalhista repousa inteiramente na presença do Partido Liberal; se este último retirar seu candidato, pode-se calcular que a maioria dos sufrágios atrás dele agrupados se transfira para o Conservador e que uma minoria se divida entre o trabalhista e a abstenção. Duas hipóteses podem então apresentar-se: ou o Partido Liberal entra em acordo com o Conservador para retirar seu candidato (mediante compensações eventuais em certas circunscrições) e o dualismo se restabelece por fusão ou por aliança muito próxima da fusão, ou o Partido Liberal obstina-se a marchar sozinho: os eleitores abandonam-no, progressivamente, e o dualismo se restabelecerá por eliminação (DUVERGER, 1970:258).

O bipartidarismo surge, portanto, por fusão ou eliminação. No primeiro caso, a redução do número de partidos se dá pela coordenação entre os partidos, no segundo a redução se deve à coordenação dos eleitores. A eliminação de terceiros partidos por ação dos eleitores seria explicada por dois fatores: um fator "mecânico" e outro "psicológico". O fator mecânico está ligado à sub-representação dos terceiros partidos em sistemas majoritários de um só turno. O fator psicológico está ligado ao fato dos eleitores compreenderem que perderão seu voto se continuarem a dá-los ao terceiro partido. A fusão ou aliança entre partidos se 
daria pela antecipação dos efeitos "mecânico" e "psicológico" por parte da direção partidária. Assim, o bipartidarismo seria o resultado das decisões dos dirigentes partidários ou das decisões dos eleitores diante das regras dadas pelo sistema eleitoral.

Após ser enunciada neste trabalho pioneiro, a "Lei de Duverger" foi testada em inúmeros estudos e exceções foram listadas e apresentadas como contraprova da influência do sistema eleitoral no sistema partidário. Outros trabalhos analisaram menos as evidências empíricas, detendo-se mais na lógica do argumento de Duverger e na sua construção teórica.

O trabalho de William Riker (1986) faz uma síntese dos “testes” da Lei de Duverger e mostra como, tanto do ponto de vista empírico, quanto do ponto de vista teórico, esta Lei precisaria sofrer algumas adaptações para manter sua validade.

Do ponto de vista empírico os casos do Canadá e da Índia seriam exceções que levariam à necessidade de se incluir novas condições à Lei de Duverger ${ }^{29}$. Além da regra da maioria também seria necessário estabelecer como condição para o bipartidarismo a ausência de um terceiro partido no nível nacional que fosse ao mesmo tempo o segundo partido no nível local, e a ausência de um "condorcet winner", isto é um partido dominante.

Do ponto de vista teórico as críticas se dirigem à premissa da racionalidade por trás do efeito psicológico da Lei, principalmente ao voto sofisticado, isto é, a deserção de um partido sem chance de vitória em favor de outro partido, menos preferido mas com maior

\footnotetext{
${ }^{29}$ Para Riker existiriam vários casos que invalidam a associação entre representação proporcional ou sistemas majoritários de dois turnos e multipardiraismo (o que chama de Hipótese de Duverger). Riker, neste caso, não procura adaptar a proposição de Duverger, ele simplesmente abandona a hipótese na sua forma determinística apesar de defender "a fairly strong probabilistic association" entre representação proporcional e sistemas de dois turnos, por um lado, e multipartidarismo por outro.
} 
chance. As evidências empíricas relatadas por Riker mostram que o voto sofisticado ocorre de fato e é algo comum, mas este comportamento não seria universal. Assim, para que a Lei tenha validade geral é preciso incorporar a possibilidade de que alguns atores não sejam racionais, nos termos previstos pelo efeito psicológico, e votem sinceramente. Isto explicaria a ocorrência de terceiros partidos mesmo em sistemas que, conforme a Lei de Duverger, deveriam ter apenas dois partidos.

Para Sartori, a fraqueza da Lei de Duverger é de natureza lógica e está em afirmar que o sistema eleitoral majoritário de um só turno é condição necessária e suficiente para o bipartidarismo. Sartori afirma que esse tipo de sistema é necessário, mas não suficiente, pois ele se aplica no nível local, onde se dá a decisão do eleitor. Portanto não explica o bipartidarismo no nível nacional mas sim local. Para essa explicação será necessária a intervenção de outra condição necessária, o tipo de sistema partidário.

Dependendo do tipo de sistema partidário o efeito do sistema eleitoral no número de partidos seria maior ou menor. Sartori distingue sistemas partidários fortes e fracos conforme a influência de fatores pessoais na decisão do eleitor. Sistemas partidários fortes seriam aqueles dominados por partidos de massa que possuem vínculos ideológicos com eleitores. Sistemas partidários fracos seriam aqueles onde imperam os vínculos pessoais.

Sistemas eleitorais fortes (majoritário de um turno) combinados com sistemas partidários fortes têm um efeito redutor no número de partidos. Sistemas eleitorais fracos representação proporcional ou majoritário de dois turnos) combinados com sistemas partidários fracos não têm influência sobre o número de partidos. Quando sistemas eleitorais fracos se combinam com sistemas partidários forte também há redução de 
partidos, mas apenas no nível local. Quando sistemas eleitorais fracos se combinam com sistemas partidários fortes pode haver redução no número de partidos, no entanto esta redução se deveria apenas ao caráter do sistema partidário. O quadro abaixo tenta tornar mais claras essas relações.

QUADRO 3.2 - INFLUÊNCIA DOS SISTEMAS ELEITORAL E PARTIDÁRIO NO NÚMERO DE PARTIDOS

\begin{tabular}{lll}
\hline & \multicolumn{2}{c}{ Sistema Partidário } \\
\cline { 2 - 3 } Sistema Eleitoral & Forte (estruturado) & Fraco (não estruturado) \\
\hline Forte & $\begin{array}{l}\text { Efeito redutivo do sistema } \\
\text { eleitoral }\end{array}$ & $\begin{array}{l}\text { Efeito bloqueador do sistema } \\
\text { partidário }\end{array}$ \\
Efeito redutivo no nível & \\
\hline \hline
\end{tabular}

Reproduzido de Sartori (1986)

Essas observações permitem a Sartori reformular a Lei de Duverger do seguinte modo:

1. Given systemic structuring and cross-constituency dispersion (as joint necessary conditions), plurality systems cause (are a sufficient condition of) a two-party format.

1.1. Alternatively, a particularly strong systemic structuring is, alone, the necessary substantive sufficient condition for causing a two-party format.

2. Given systemic structuring but failing cross-constituency dispersion, plurality systems cause (are a sufficient condition of) the elimination of bellow-plurality parties but cannot eliminate, and thus permit, as many parties above two as are permitted by sizeable above-plurality concentrations.

3. Given systemic structuring, proportional representation obtains a reductive effect caused (as a sufficient condition) by its non proportionallity. 
Hence, the greater the impurity of PR, the higher the entry costs for the smaller parties, and stronger the reductive effect; and conversely, the lesser the impurity, the feebler the reductive effect.

3.1. Alternatively, a particularly strong systemic structuring is alone, the necessary and sufficient condition for maintaining whatever party format preexisted the introduction of PR.

4. Failing systemic structuring and assuming pure PR, that is, an equal cost of entry for all, the number of parties is free to become as large as the quota permits (SARTORI, 1986:63-64).

Com essa reformulação Sartori dá conta das exceções à Lei de Duverger, como o caso da Índia que seria um exemplo de sistema partidário não estruturado. Essas alterações também permitem estender os efeitos redutores para sistemas que adotam a representação proporcional. Quando a representação proporcional é "impura” e o sistema partidário é estruturado, há redução do número de partidos devido à desproporcionalidade do sistema ${ }^{30}$.

Gary Cox irá se debruçar sobre a Lei de Duverger ao investigar os problemas de coordenação característicos da competição eleitoral. Cox (1997) está preocupado com as consequiências da coordenação estratégica e com as características estruturais que determinam a natureza dos problemas de coordenação em diferentes sistemas políticos. Nesta perspectiva a redução do número de partidos seria uma das conseqüências do

\footnotetext{
${ }^{30}$ O problema dessa análise é que na busca da explicação da passagem do efeito no nível local da Lei de Duverger para o nível nacional ela deixa de fora quase todos os países que não são da Europa Ocidental já que, conforme o próprio Sartori, é lá basicamente que se encontram partidos de massa nacionalmente organizados. Como veremos mais à frente a crítica de Cox à Sartori é que ele afirma o consequente ao colocar como condição do efeito do sistema eleitoral no nível nacional a organização dos partidos nacionalmente.
} 
processo de coordenação, sendo necessário explicar em que condições e quais os mecanismos que fazem com que isso ocorra.

Para Cox são três os fatores que determinam a natureza do problema de coordenação: as instituições eleitorais, as motivações políticas dos atores e as expectativas públicas (public expectations). Cox descreve a relação entre essas variáveis da seguinte forma:

Electoral institutions determine how votes translates into seats. If political actors care mostly about winning seats in the current elections, then the influence of electoral institutions on their goals is direct. If, in addition, actors' expectations about each other's vote shares are precise and consensual, then a well-structured coordination game emerges in which the prospects for successful coordination are good. This model corresponds to the standard Duvergerian approach to legislative elections in the electoral studies literature (COX, 1997:8).

Para Cox, o efeito redutor descrito por Duverger aparece toda vez que as "elites" políticas (líderes partidários, contribuintes, formadores de opinião, etc.) consigam se coordenar em torno dos candidatos com maior chance de vitória em um primeiro momento ou, caso falham, os eleitores o façam em um segundo momento. Para Cox "any electoral system can be characterized by an equilibrium upper bound on the number of candidates (or party lists), such that if the actual number exceeds this upper bound there is a tendency for instrumentally rational voters to concentrate on a smaller number" (COX, 1997:30). Ao estabelecer que todo sistema eleitoral gera um upper bound no número de candidatos, Cox concorda com Sartori que afirmava que a representação proporcional também 
estabeleceria um upper bound em maior ou menor grau conforme sua "pureza". Cox generaliza a lei de Duverger e afirma que em qualquer sistema eleitoral o upper bound é dado pela fórmula M+1 onde M é o número de cadeiras em jogo, ou seja, a magnitude do distrito.

Por traz desta generalização está um modelo de comportamento do eleitor baseado na suposição de que este detém informação completa (quanto à expectativa pública e não quanto ao comportamento individual de cada eleitor) e age de maneira instrumental, ele irá procurar concentrar seu voto em candidatos viáveis, isto é, naquele candidato que estiver lutando pela última cadeira em jogo, pois é aí que seu voto fará diferença. Votar em um candidato que já está eleito (na expectativa dos eleitores) ou em outro que já está derrotado seria desperdiçar o voto.

Estas premissa comportamentais são utilizadas por Cox para construir seu modelo, quais sejam: 1) os eleitores têm preferências definidas e são instrumentalmente racionais a curto prazo, isto é, eles só se importam com o voto que pode influir no resultado da eleição corrente; 2) os eleitores têm informação incompleta quanto às preferências uns dos outros mas têm "crenças" sobre qual a distribuição dos votos; 3) as expectativas são racionais, isto é, a crença dos eleitores sobre quais candidatos são os mais fortes e quais são os mais fracos estão corretas; 4) os eleitores diante de suas preferências, crenças e expectativas procuram maximizar sua utilidade esperada votando na opção que lhe traga o maior benefício com maior probabilidade.

Esse modelo levaria a dois resultados: um seria uma situação de equilíbrio duvergeriano, onde o nível de voto estratégico é tão grande que o apoio a um terceiro partido desaparece 
completamente, no caso da plurality rule, ou se fixa no limite $\mathrm{M}+1$ nos outros casos. Outro resultado seria um equilíbrio não-duvergeriano onde dois ou mais candidatos estão de tal forma empatados que fica impossível para o eleitor decidir qual tem maiores chances de vencer e, portanto, para qual se deve dar o voto estratégico. Neste último caso, não haveria redução no número de candidatos e todos estariam no mesmo patamar de votos.

A grande contribuição de Cox está no rigor, na formalização do modelo. A partir desta formalização é possível especificar as condições em que a lei de Duverger se aplica. A lei só se aplica, novamente, se os eleitores forem instrumentalmente racionais e se importarem apenas com o resultado daquela eleição descontando inteiramente o peso das eleições futuras; se os eleitores tiverem acesso a informações públicas e corretas sobre a colocação dos candidatos; e se os eleitores se ajustarem uns ao comportamento dos outros. Esse ajuste levaria ao equilíbrio duvergeriano.

Desta formulação Cox deriva um teste para verificar a presença ou não do voto estratégico no nível local, que batiza de teste de bimodalidade. A lógica do teste é simples: em um equilíbrio duvergeriano a diferença entre os votos do primeiro candidato derrotado (o candidato na $\mathrm{M}+1^{\mathrm{a}}$ posição) e os votos do segundo candidato derrotado (na $\mathrm{M}+2^{\mathrm{a}}$ posição) é muito grande. Portanto se dividirmos votos do segundo candidato derrotado pelos votos do primeiro candidato derrotado o resultado seria muito pequeno, tendendo a zero. Já em um equilíbrio não-duvergeriano, a diferença da votação do segundo candidato derrotado para o primeiro é mínima e a razão se aproximaria de um já que não haveria voto estratégico. O nome do teste relaciona-se à forma esperada do gráfico quando se calcula estas razões para um determinado número de eleições: a maior parte dos casos 
estariaconcentrada nas duas pontas do eixo $x$, formando picos nestas regiões e um vale na região central.

Cox aplica o teste de bimodalidade nos casos de eleição majoritária em primeiro turno e nos casos de voto único não transferível (SNTV). Os casos analisados (Inglaterra para SMSP e Japão para SNTV) mostram que é possível identificar o voto estratégico em alguns casos, principalmente naqueles em que os distritos são mais competitivos.

Ao estender a análise do voto estratégico para sistemas de representação proporcional, Cox irá aprofundar os achados de Sartori, que afirmava haver voto estratégico também nestes sistemas. Cox irá generalizar a lei de Duverger mostrando que este voto estratégico leva a uma redução no número de candidatos tendo a fórmula $\mathrm{M}+1$ como upper bound tanto para o sistema de sobras quanto nos sistemas de divisores. Cox também irá mostrar que, apesar disto, o efeito do voto estratégico não reduz necessariamente o número de listas, já que se pode desertar um candidato bem colocado para outro na mesma lista para garantir que esta saia vitoriosa. Por fim, Cox irá mostrar que o efeito do voto estratégico desaparece em distritos com magnitude maior que cinco.

\section{2 - Testando os efeitos da Lei de Duverger nas eleições majoritárias no} Brasil

Pretendo agora buscar evidências que sustentem ou não a análise de Cox no caso brasileiro e assim verificar se há indícios de voto estratégico no país. O Brasil é um excelente laboratório para testar esta teoria já que nele coexistem os sistemas de voto majoritário de um turno, majoritário de dois turnos, representação proporcional além de uma variação do 
single non-transferable vote (SNTV). As cidades com menos de 200 mil habitantes adotam o primeiro sistema; as cidades com mais de 200 mil habitantes, os estados e a União, nas eleições para o executivo, adotam o segundo; as eleições para as câmaras de vereadores, deputado estadual e deputado federal adotam a representação proporcional; e a eleição para o Senado que se aproxima do sistema majoritário de um turno, quando está em jogo apenas uma vaga $(\mathrm{M}=1)$, e do $\mathrm{SNTV}^{31}$ quando são duas as vagas em disputa $(\mathrm{M}=2)$.

Neste trabalho iremos nos concentrar nas eleições majoritárias diferenciando eleições sob sistema majoritário de um turno e eleições sob sistema majoritário de dois turnos. Para analisar os efeitos do sistema majoritário de um turno no número de candidatos iremos buscar evidências de voto estratégico nos municípios com menos de 200 mil habitantes. Para testar os efeitos redutores do sistema de dois turnos iremos analisar as eleições para governador do estado.

\section{Testando a Lei de Duverger nas eleições de um só turno para prefeito.}

Para testar os efeitos das eleições majoritárias de um turno no número de partidos examinaremos as eleições para prefeito em 2.752 municípios brasileiros que tinham entre 10 mil e 200 mil habitantes $^{32}$, nas eleições de 1996 a 2008. No total foram analisadas 11.008 eleições. O Gráfico 3.1 mostra a distribuição do número de candidatos na disputa

\footnotetext{
${ }^{31}$ SNTV na verdade seria mais apropriado chamá-lo de DNTV já que em $M=2$ cada eleitor têm direito a dois votos

${ }^{32}$ Cox alerta para o fato de que distritos pequenos não enfrentam problemas de coordenação. Assim iremos examinar as eleições para prefeito em municípios com mais de 10 mil habitantes. O limite superior de 200 mil habitantes é aquele a partir do qual as eleições passam a ser de dois turnos.
} 
por eleição. O primeiro aspecto que chama a atenção é o grande número de disputas entre apenas dois candidatos - 3754 ou $34,1 \%$ do total. Também chama a atenção o fato de que em $2 / 3$ das eleições concorreram três ou menos candidatos e mais de $85 \%$ tinham menos que quatro candidatos.

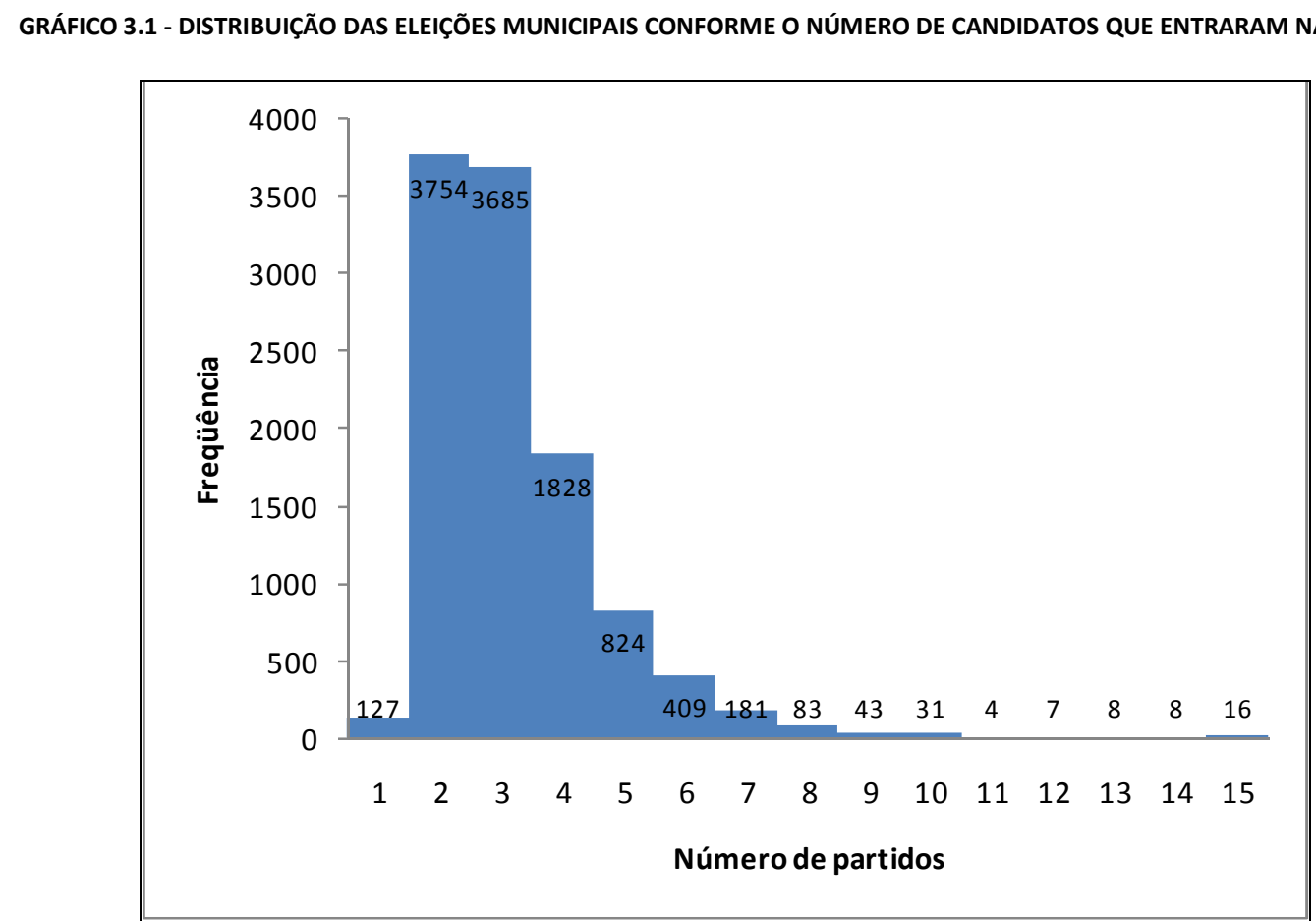

Fonte: TSE

Embora o grande número de disputas com apenas dois candidatos seja um forte indício de coordenação estratégica entre as elites políticas, para verificarmos se houve voto estratégico devemos considerar apenas aquelas eleições onde entraram mais de dois candidatos. 
O Gráfico 3.2 mostra a razão entre os votos do segundo candidato derrotado (S) e o primeiro candidato derrotado $(\mathrm{F})$ para cada eleição.

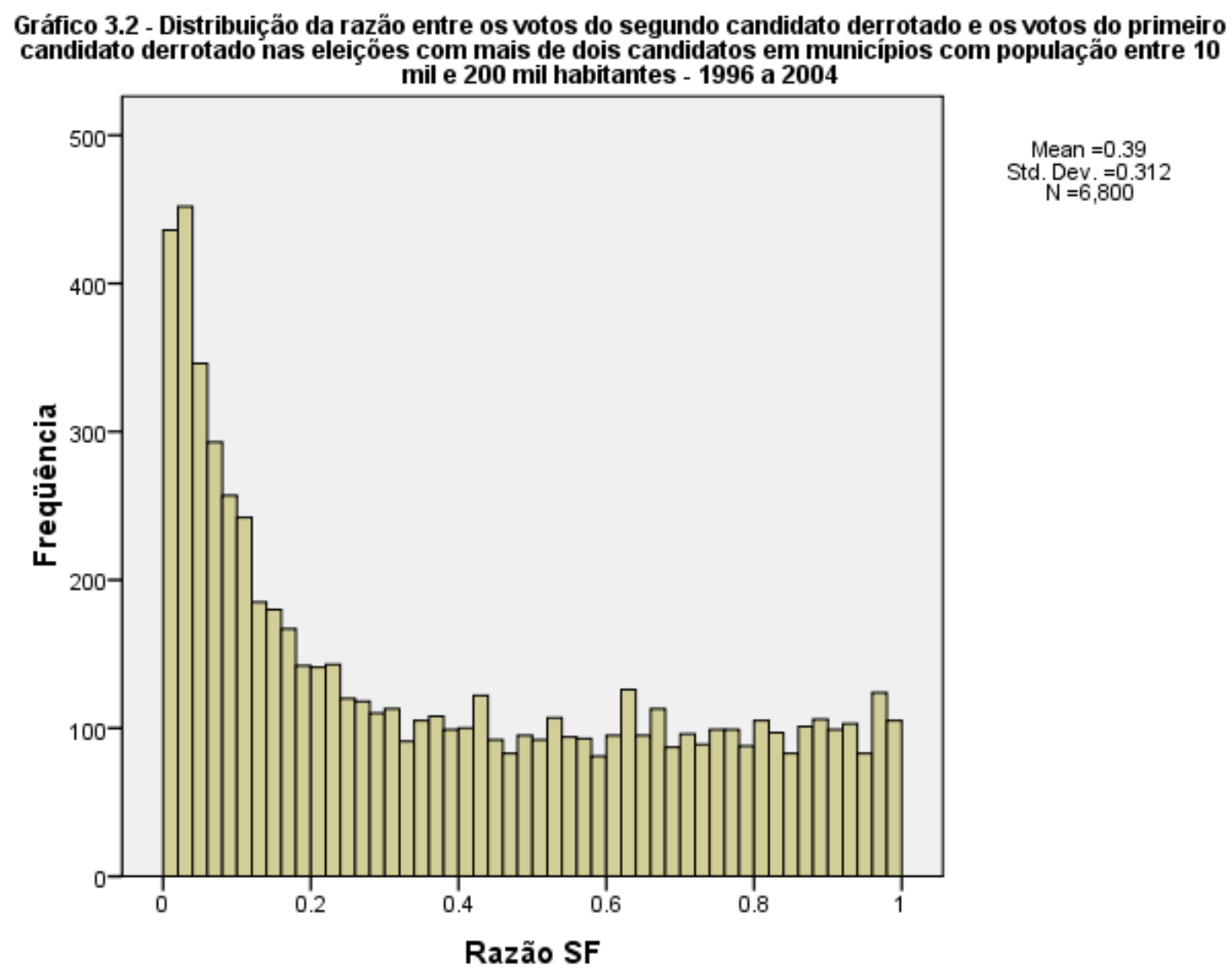

Esse gráfico mostra uma grande concentração de casos próximos a zero o que significa que há equilíbrio duvergeriano, isto é, na maior parte das eleições os eleitores concentraram seus votos nos candidatos mais viáveis. Em $50 \%$ dos casos a proporção de votos do segundo perdedor para o primeiro perdedor foi menor que $31 \%$, isto é, o terceiro colocado teve no máximo um terço dos votos do segundo colocado. Em $25 \%$ dos casos a diferença do segundo colocado para o terceiro colocado foi mais acachapante com este obtendo dez 
vezes menos votos que aquele. Em apenas $35 \%$ dos casos o terceiro colocado alcançou mais da metade dos votos do segundo e só em $10 \%$ das vezes ele chegou a mais de $87 \%$.

O Gráfico 3.2 também mostra que não há indício de equilíbrio não-duvergeriano dada a uniformidade da distribuição após os 30\% de razão SF. Diferente dos resultados de Cox, essa situação se repete mesmo em distritos mais competitivos, isto é, aqueles em que em eleição prévia o vencedor ganhou por uma margem menor do que $20 \%$.

Embora a hipótese de que eleições majoritárias de um só turno levam à deserção do terceiro candidato parece se confirmar com estes dados, também valem aqui as explicações alternativas dadas por Cox, especialmente a que sustenta que a coordenação se dá nas elites políticas.

\section{Testando a Lei de Duverger nas eleições de dois turnos para governador de estado}

As eleições para governador de estado nos fornecem uma boa base para testar os efeitos da Lei de Duverger em sistemas majoritários de dois turnos. Entre 1990 e 2006 foram realizadas cinco eleições para Governador do estado nos 27 estados da federação totalizando 135 eleições. Dado que se trata de eleições majoritárias de dois turnos, esperaríamos que nas eleições para governador tivéssemos, no máximo, três candidatos viáveis conforme formulação de Cox (1997). A Tabela 3.1 nos mostra o número de candidatos por eleição. 


\begin{tabular}{|c|c|c|c|c|c|}
\hline \multirow[b]{2}{*}{ Estado } & \multicolumn{5}{|c|}{ Ano da Eleição } \\
\hline & 1990 & 1994 & 1998 & 2002 & 2006 \\
\hline Acre & 6 & 6 & 5 & 6 & 3 \\
\hline Alagoas & 5 & 6 & 6 & 7 & 9 \\
\hline Amapá & 8 & 5 & 5 & 7 & 8 \\
\hline Amazonas & 5 & 5 & 5 & 6 & 7 \\
\hline Bahia & 7 & 6 & 5 & 9 & 8 \\
\hline Ceará & 4 & 6 & 6 & 8 & 7 \\
\hline Distrito Federal & 6 & 7 & 6 & 9 & 7 \\
\hline Espírito Santo & 5 & 5 & 6 & 8 & 7 \\
\hline Goiás & 5 & 6 & 7 & 7 & 7 \\
\hline Maranhão & 4 & 6 & 7 & 5 & 8 \\
\hline Mato Grosso & 6 & 4 & 6 & 6 & 9 \\
\hline Mato Grosso do Sul & 4 & 6 & 5 & 7 & 5 \\
\hline Minas Gerais & 8 & 10 & 7 & 7 & 7 \\
\hline Pará & 5 & 7 & 6 & 7 & 7 \\
\hline Paraíba & 6 & 7 & 6 & 7 & 7 \\
\hline Paraná & 7 & 9 & 5 & 11 & 9 \\
\hline Pernambuco & 6 & 7 & 7 & 8 & 8 \\
\hline Piauí & 5 & 5 & 6 & 9 & 7 \\
\hline Rio de Janeiro & 5 & 9 & 14 & 9 & 11 \\
\hline Rio Grande do Norte & 5 & 5 & 7 & 7 & 7 \\
\hline Rio Grande do Sul & 5 & 8 & 8 & 11 & 9 \\
\hline Rondônia & 7 & 8 & 7 & 8 & 7 \\
\hline Roraima & 7 & 6 & 6 & 6 & 8 \\
\hline Santa Catarina & 7 & 6 & 8 & 7 & 8 \\
\hline São Paulo & 8 & 10 & 12 & 12 & 9 \\
\hline Sergipe & 4 & 5 & 7 & 8 & 6 \\
\hline Tocantins & 5 & 6 & 5 & 6 & 5 \\
\hline
\end{tabular}

Fonte: Nicolau, Jairo Dados Eleitorais Brasileiros (1982-2006)

Obs: O número efetivo de candidatos foi calculado como $1 / \sum \mathrm{P}_{\mathrm{i}}^{2}$ onde $\mathrm{Pi}$ é a proporção de votos de cada candidato

Vemos que, diferente do caso das eleições municipais, o número médio de candidatos ao governo de estado tem se mantido entre 6 e 7 entre 1990 e 2006, o menor número de candidatos se deu no Acre em 2006 (3) e o maior se deu no Rio de Janeiro em 1998 (14). Isto está de acordo com a previsão de que em sistemas majoritários de dois turnos haveria mais candidatos do que em sistemas majoritários de turno único, no entanto, como o número é bem maior que três parece, à primeira vista, que não há coordenação eleitoral entre as elites. No entanto, estes dados não permitem chegar a esta conclusão, pois não 
dizem nada sobre a viabilidade dos partidos que entraram na disputa e, muito menos, sobre a votação que estes partidos receberam. Para verificar se há coordenação eleitoral precisamos analisar os dados referentes aos partidos viáveis e para verificar o voto estratégico deveremos examinar a votação dos partidos. Começaremos pela coordenação eleitoral.

Se observarmos o número efetivo de candidatos ao governo de estado ${ }^{33}$, apresentados na Tabela 3.2, veremos um quadro um tanto diferente daquele observado na Tabela 3.1.

${ }^{33}$ Seguindo a fórmula de Laakso e Taagepera (1979), o número efetivo de candidatos foi calculado como $1 / \sum \mathrm{Pi} 2$ onde Pi é a proporção de votos de cada candidato. 


\begin{tabular}{lccccr}
\cline { 2 - 6 } & \multicolumn{5}{c}{ Ano da Eleição } \\
\hline Estado & 1990 & 1994 & 1998 & 2002 & 2006 \\
\hline Acre & 4,03 & 1,74 & 2,36 & 1,93 & 3,40 \\
Alagoas & 2,03 & 1,52 & 2,04 & 2,25 & 2,42 \\
Amapá & 3,33 & 2,76 & 2,86 & 3,68 & 2,31 \\
Amazonas & 2,18 & 1,15 & 2,05 & 2,74 & 2,38 \\
Bahia & 2,69 & 2,99 & 1,89 & 2,28 & 2,15 \\
Ceará & 2,28 & 2,23 & 2,17 & 2,87 & 1,98 \\
Distrito Federal & 2,64 & 2,97 & 2,72 & 2,76 & 2,81 \\
Espírito Santo & 2,89 & 3,07 & 2,37 & 2,15 & 1,55 \\
Goiás & 2,28 & 2,69 & 2,19 & 2,55 & 2,45 \\
Maranhão & 2,70 & 2,20 & 1,73 & 2,25 & 2,76 \\
Mato Grosso & 2,06 & 1,74 & 2,27 & 2,64 & 2,08 \\
Mato Grosso do Sul & 2,18 & 1,92 & 3,02 & 2,40 & 1,92 \\
Minas Gerais & 4,17 & 1,78 & 2,71 & 2,31 & 1,56 \\
Pará & 2,73 & 2,16 & 2,78 & 3,63 & 2,84 \\
Paraíba & 2,74 & 2,43 & 1,48 & 2,51 & 2,07 \\
Paraná & 3,36 & 1,67 & 2,07 & 4,37 & 2,88 \\
Pernambuco & 2,17 & 2,47 & 2,06 & 2,07 & 3,01 \\
Piauí & 2,25 & 2,74 & 2,68 & 2,19 & 2,18 \\
Rio de Janeiro & 2,34 & 3,77 & 2,76 & 2,85 & 4,22 \\
Rio Grande do Norte & 2,51 & 2,32 & 2,34 & 3,46 & 2,07 \\
Rio Grande do Sul & 3,41 & 2,62 & 2,33 & 3,05 & 3,81 \\
Rondônia & 5,03 & 2,90 & 3,49 & 5,07 & 2,64 \\
Roraima & 2,99 & 3,08 & 1,60 & 2,09 & 2,06 \\
Santa Catarina & 2,78 & 1,79 & 1,29 & 3,08 & 2,72 \\
São Paulo & 3,26 & 3,28 & 2,92 & 3,34 & 2,28 \\
Sergipe & 1,65 & 2,21 & 2,92 & 2,97 & 2,09 \\
Tocantins & 2,55 & 1,21 & 2,03 & 2,07 & 2,06 \\
\hline \hline Fonte:Nicos & 2,03 & \\
\hline
\end{tabular}

Fonte: Nicolau, Jairo Dados Eleitorais Brasileiros (1982-2006)

Obs: O número efetivo de candidatos foi calculado como $1 / \Sigma \mathrm{P}_{\mathrm{i}}^{2}$ onde $\mathrm{Pi}$ é a proporção de votos de cada candidato

A Tabela 3.2 nos mostra que quase todos os estados sempre apresentam três ou menos candidatos efetivos. Os únicos estados que apresentaram significativamente mais de três candidatos $^{34}$ foram Minas Gerais e Rondônia em 1990, São Paulo em 1994, Rondônia em

\footnotetext{
${ }^{34}$ Por significativamente entendo valores acima de 3,1. Esse número é equivalente a uma grande diferença entre o quarto e terceiro colocado, mais de 50\%. Um número maior que 3,1 significa uma diferença bem menor.
} 
1998, o Amapá, o Pará, o Paraná e novamente Rondônia e São Paulo em 2002, o Acre, o Rio de Janeiro e o Rio Grande do Sul em 2006.

O número de candidatos efetivos está de acordo com as previsões de Duverger e Cox sobre os efeitos das eleições majoritárias de dois turnos. Vemos aqui que, em $86 \%$ das eleições, os votos se concentram em três ou menos candidatos efetivos. Também cabe observar que em $27 \%$ dos casos haviam apenas dois candidatos efetivos. Esses números estão bem abaixo do limite de quatro candidatos proposto por Duverger.

Para entendermos melhor o porquê da diferença entre o número de candidatos efetivos e o total de candidatos devemos observar que $80 \%$ dos candidatos que obtiveram mais de $10 \%$ de votos pertencem a 7 partidos: PT, PDT, PMDB, PSDB, PTB, PFL/DEM, PDS/PP. O que estes sete partidos têm em comum é que todos possuem mais de 1 milhão de filiados ${ }^{35}$, ou seja, trata-se do conjunto de grandes partidos. Outra constatação importante é que em apenas 36 das 135 eleições havia mais de três candidatos destes partidos.

Portanto quando consideramos apenas os partidos grandes vemos que a situação repete aquela das eleições para prefeito, apresentando uma razoável dose de coordenação estratégica. O que infla o número de candidatos é o contingente de pequenos partidos que se lançam na disputa. O que move estes partidos?

Observando os dados referentes aos 19 pequenos partidos que tiveram candidatos com mais de $10 \%$ de votos nas eleições entre 1990 e vemos 2006 que apenas sete deles participaram de mais de duas eleições. Esses partidos parecem abrigar candidatos viáveis que, por diversas razões, não conseguiram espaço em legendas maiores ou optaram por não se lançar

\footnotetext{
${ }^{35}$ TSE em www.tse.gov.br último acesso (20/03/2009)
} 
por nenhuma delas. É o caso, por exemplo, do ex-presidente Fernando Collor de Mello que, após o desgaste do impeachment teve que se candidatar pelo PRTB ao governo de Alagoas em 2002. Também foi o caso do PSL do Amazonas em 1998 que abrigou a candidatura de Eduardo Braga prefeito de Manaus que rompeu com seu aliado, o governador Amazonino Mendes e não encontrou espaço em partidos da oposição. Outro caso é o de João Durval, na Bahia, que, após romper em 1986 com o PFL de Antônio Carlos Magalhães, se abrigou no PMN para tentar ser novamente governador em 1994.

Há também caso de figuras polêmicas que não conseguem entrar em partidos grandes por questões extra-políticas como os casos dos ex-prefeitos Melki Donadon, candidato pelo PSC ao governo de Rondônia, e Djair Camata, candidato pelo PSD ao governo do Espírito Santo. O primeiro seria preso em 2002 por corrupção e o segundo, acusado de ter sido membro do grupo de extermínio Escuderie Le Cocq, morreu em 2006 pouco antes de dar seu depoimento na CPI do Narcotráfico.

Seja como for, o fato é que as tentativas de entrada nas eleições para governo, seja por membros do establishment político, seja por outsiders, raramente rendem frutos. A votação obtida pelos pequenos e micro partidos é, em geral, muito pequena.

Para entendermos ainda melhor a motivação dos pequenos partidos precisamos observar todos os partidos que lançaram candidatos e não só aqueles que obtiveram mais de $10 \%$ de votos. O Gráfico 3.3 mostra a distribuição do número de vezes em que um partido lançou candidatos a governador entre 1990 e 2006. 


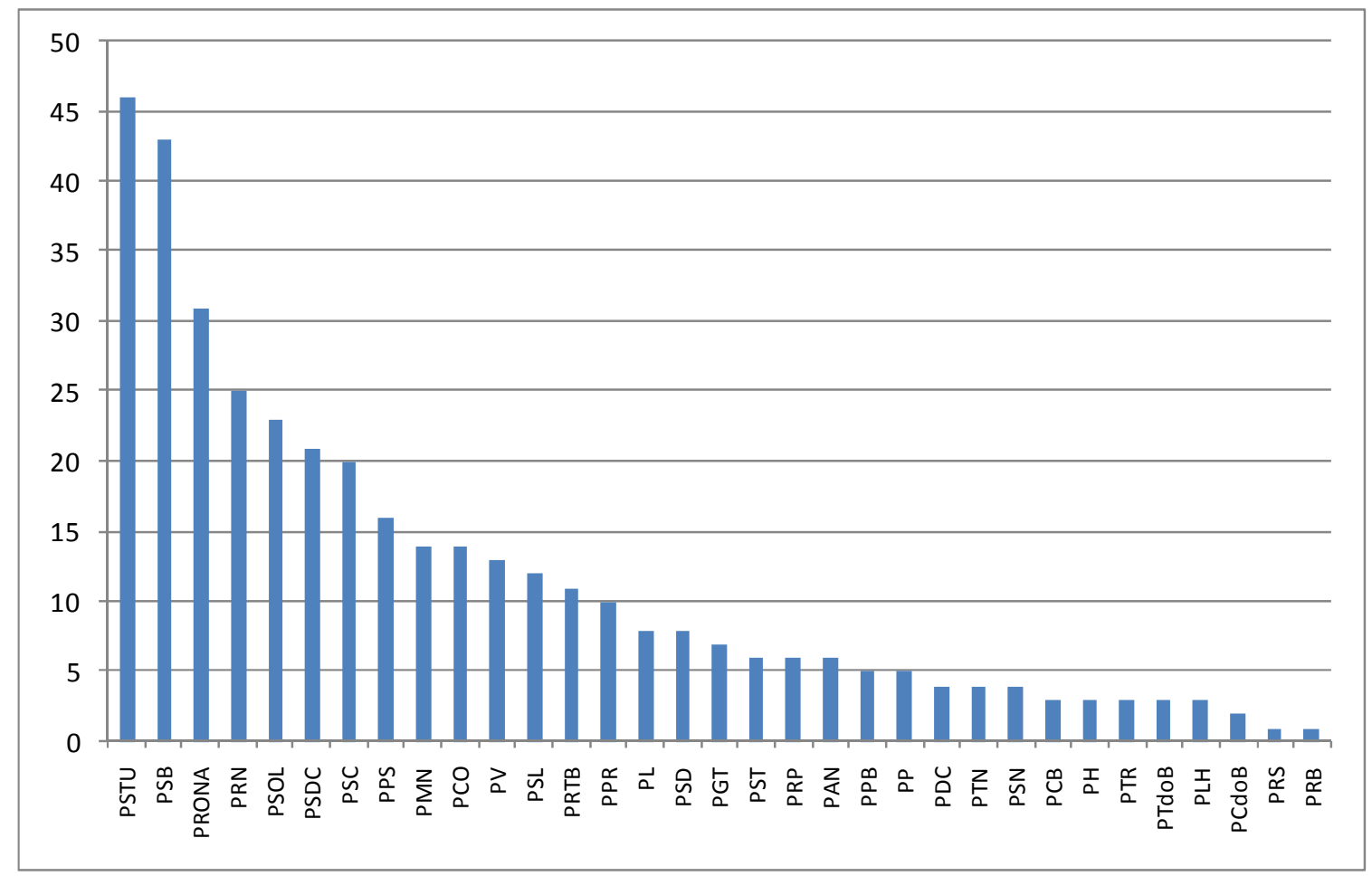

Ao todo, 33 pequenos partidos lançaram candidatos a governador. Em 50\% dos casos estes partidos lançaram candidatos em menos de oito disputas e em $40 \%$ em menos de cinco. Levando em conta que para se constituir um partido deve ter diretórios em no mínimo nove estados o fato de mais da metade lançar menos de nove candidatos indica a dificuldade destes partidos em entrar nas disputas pelo governo do estado.

Esses dados estão de acordo com a literatura sobre competição eleitoral que sugere que os partidos pequenos geralmente se guiam por motivos diferentes daqueles dos partidos grandes (DUVERGER, 1970, PANEBIANCO, 2005). Eles algumas vezes estão 
preocupados em estabelecer uma reputação ou são partidos ideológicos que permanecem sempre numa posição mais extrema, neste caso "jogam” no longo prazo. Outras vezes são partidos de protesto ou "legendas de aluguel" de natureza mais efêmera que têm outros objetivos como garantir certo número de cadeiras no legislativo. Em todo caso, independente das motivações que possamos atribuir a eles, estes partidos não são “racionais" no sentido downsiano ${ }^{36} \mathrm{e}$, portanto, não esperaríamos que eles viessem a coordenar sua entrada, mesmo porque eles também teriam pouco a oferecer em uma barganha.

Portanto a configuração das disputas para o governo do estado envolve na média entre seis e sete candidatos, três de partidos grandes, que abocanham a maior parte dos votos, e três de partidos pequenos que quase sempre ficam abaixo dos $10 \%$ de votação. Dado que, na maior parte das vezes, apenas três dos grandes entram na disputa, temos fortes indícios de que no caso destes partidos há coordenação por parte das elites políticas. Para verificar se nos casos em que esta coordenação não ocorreu houve coordenação por parte dos eleitores, precisamos utilizar o teste de bimodalidade de Cox.

O Gráfico 3.4 mostra a distribuição das razões SF nas eleições para governador no Brasil, em que houve segundo turno, entre 1990 e $2006^{37}$.

\footnotetext{
${ }^{36}$ Os modelos de voto e de entrada estratégicos partem da premissa de que eleitores e lideranças são "short-term instrumentally rational" o que quer dizer que eles estão pensando nas conseqüências imediatas de suas ações e irão sempre optar pela opção que maximize seus benefícios a determinado custo.

${ }^{37}$ Excluimos as eleições em que não houve segundo turno porque nestes casos, com o primeiro colocado obtendo mais de $50 \%$ dos votos, a votação do terceiro e quarto colocados é, em geral, muito pequena e a razão entre elas está próxima a um dando a idéia errônea de que os eleitores não teriam coordenado o voto. Na verdade pode ter havido coordenação no sentido de se resolver a disputa no primeiro turno.
} 


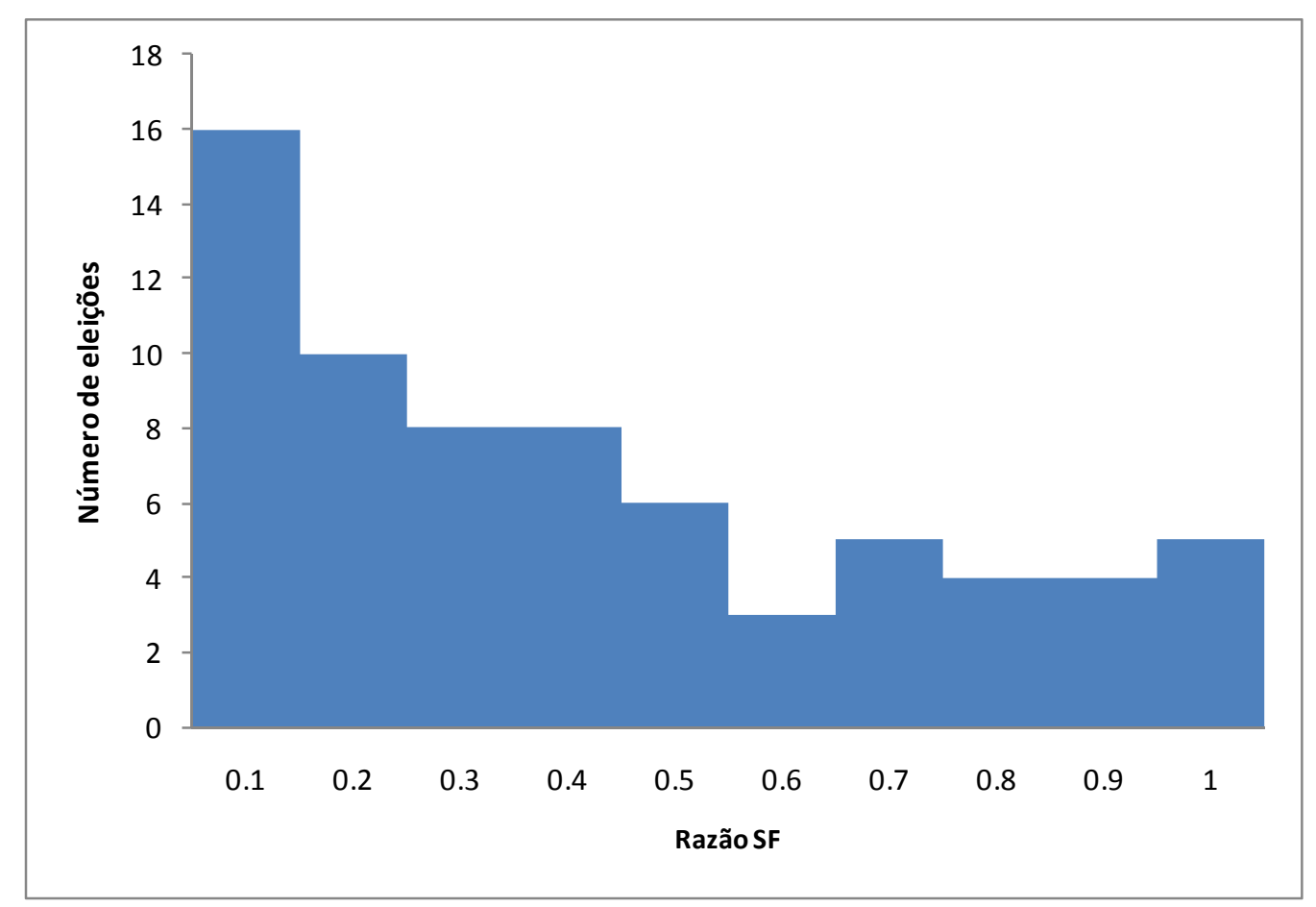

Antes de tudo é importante ressaltar que em 64 das 135 eleições para governador entre 1990 e 2006 não houve segundo turno. Nos casos em que houve segundo turno vemos que que a razão de votos entre o quarto e o terceiro colocado fica próxima a zero como nas eleições municipais. Em 49\% das eleições o quarto colocado recebeu menos do que um terço dos votos do terceiro colocado e em $69,5 \%$ das vezes ele recebeu menos que a metade dos votos. Esses resultados são parecidos com os resultados que vimos no caso das eleições de um só turno e indicam a presença de equilíbrio duvergeriano. 


\section{Testando a Lei de Duverger para as eleições para Presidência da República}

Embora o número de eleições para presidente seja pequeno para permitir qualquer conclusão há também nelas uma tendência de coordenação por parte das elites e indícios de equilíbrio duvergeriano. O quadro 3.2 mostra o número de candidatos em cada disputa.

QUADRO 3.3 - NÚMERO DE CANDIDATOS LANÇADOS PELOS GRANDES PARTIDOS E RAZÃO SF NAS DISPUTAS PELA PRESIDÊNCIA DA REPÚBLICA ENTRE 1994 E 2006

\begin{tabular}{lrrrrr}
\hline & \multicolumn{1}{c}{ Ano } \\
\hline & 1989 & 1994 & 1998 & 2002 & 2006 \\
\hline Número de candidatos & & & & & \\
lançados por grandes & 7 & 5 & 2 & 2 & 3 \\
partidos & 0,70 & 0,59 & 0,19 & 0,67 & 0,39 \\
Razão SF &
\end{tabular}

Fonte:TSE

Obs.: Os partidos considerados grandes são: PP, PMDB, PT, PDT, PTB, PSDB e DEM. A Razão SF foi calculada dividindo-se os votos do quarto colocado pelos votos do terceiro colocado

Na primeira eleição para presidente não houve coordenação e todos os sete partidos grandes lançaram candidatos. A falta de coordenação pode ser atribuída à ausência de informação sobre as diferentes chances de cada partido. Já na segunda eleição surge a primeira aliança entre grandes partidos (PSDB, PFL e PTB) ${ }^{38}$. A partir desta eleição em nenhum outro caso se apresentaram mais de três partidos grandes.

A razão SF, declinante nas três primeiras eleições aumenta em 2002 quando novas forças oferecem candidatos como o PPS, que lança Ciro Gomes e o PSB que lança Anthony Garotinho. Em 2006 a Razão SF volta a se fixar bem abaixo de 0,5. Isto indica que mais do que ação estratégica dos eleitores nas eleições para presidente a redução do número de candidatos se deve à coordenação pré-eleitoral.

\footnotetext{
${ }^{38}$ O PT se alia ao PSB que, embora não tenha mais de um milhão de filiados, tinha importância eleitoral ao ter entre seus quadros figuras como a do Governador de Pernambuco Miguel Arraes.
} 


\section{Conclusão}

Os testes que fizemos comprovam os efeitos da Lei de Duverger tanto em eleições majoritárias de um turno quanto em eleições majoritárias de dois turnos. Vimos que nestas eleições ocorre o equilíbrio duvergeriano e que o candidato na $\mathrm{M}+2^{\mathrm{a}}$ posição tem, em geral, bem menos votos do que o candidato na $\mathrm{M}+1^{\mathrm{a}}$ posição, o que indica voto estratégico.

Também chama a atenção a prevalência da coordenação pré-eleitoral. O número de candidatos lançados pelos grandes partidos em uma mesma eleição nas disputas para prefeito, governador ou até mesmo presidente se iguala ao limite $\mathrm{M}+1$ na maior parte das vezes não dando oportunidade para a ocorrência do voto estratégico.

Isto estaria de acordo com as constatações de Cox que analisando o caso Japonês sugere que estes resultados se devem mais à ação das elites (que fariam um apelo para que o eleitor não desperdiçasse seu voto) do que à racionalidade do eleitor. Nas palavras de Cox:

My personal bias is strongly toward the elite-level hypotheses, as it is in the study of turnout. I think strategic voting survives, both in theory and practice, because one of the things outcome-oriented elites can do in close races to reallocate resources from trailing to front-running candidates is flood the mass media with 'wasted vote' arguments (including therein both the relevant evidence on candidate standings and the basic logic motivating a strategic vote) (COX, 1997: 98).

Para Cox (assim como para Duverger e Riker) a antecipação do voto estratégico por parte das elites pode levar à decisão de se lançar ou não uma candidatura ou lista. Isso daria a 
racionalidade por trás da decisão de um partido em estabelecer uma coligação eleitoral. No entanto, assim como a coordenação pré-eleitoral está presente em grande parte dos casos, a falta de coordenação não é fenômeno raro.

No próximo capítulo iremos investigar o porquê desta variação da ocorrência de coordenação entre as elites. Chegaremos a conclusões diferentes daquelas da literatura corrente que defende que "uma linha de análise, que leva mais adiante a fronteira do explicado, parte das relações entre a ideologia, as bases sociais dos partidos e as coligações eleitorais" (SOARES, 2001). Veremos que a ideologia pesa pouco na explicação da decisão de um partido de lançar ou não um candidato, por outro lado veremos a importância da organização partidária nesta decisão. 


\section{CAPÍTULO 4 - COORDENAÇÃo ELEITORAL E ORGANIZAÇÃO PARTIDÁRIA}

\section{Introdução}

Em maio de 1994 o PMDB tinha duas opções diante das eleições presidenciais que se aproximavam: lançar candidato próprio ou apoiar uma das candidaturas que se anunciavam. Conforme pesquisas eleitorais da época as chances dos candidatos se distribuía da seguinte forma, em primeiro lugar vinha Luis Inácio Lula da Silva pelo PT, com 42\% das intenções de voto; em segundo lugar, com $15 \%$ de intenção de votos, vinha o ex-ministro da Fazenda e autor do Plano Real, Fernando Henrique Cardoso do PSDB; em terceiro lugar vinha José Sarney com 14\% dos votos; em quarto lugar vinha Leonel Brizola com $8 \%$ e, em quinto, Orestes Quércia com $7 \%$ de intenção de votos ${ }^{39}$.

A candidatura com mais chances era, sem dúvida, a de Lula, mas uma aliança com o PT estava fora de cogitação por divergências ideológicas. A candidatura Fernando Henrique Cardoso (FHC) tinha apoios fortes tanto do Presidente Itamar quanto do PFL, atual DEM, o que daria uma grande vantagem ao candidato em termos de recursos para a campanha. FHC também era o autor do Plano Real e os efeitos de um plano de estabilização bem sucedido era conhecido por todos, principalmente pelos peemedebistas que foram grandemente beneficiados pelo Plano Cruzado nas eleições de 1986. Assim as chances de vitória FHC,

\footnotetext{
${ }^{39}$ Rossi, Clóvis “Veja a situação dos candidatos presidenciais a cinco meses da eleição" publicado na Folha de São Paulo de 06/05/1994, pg. 1-7.
} 
apesar dos 15\%, eram boas. Além disso, o PSDB era um partido próximo ideologicamente e estava aberto a uma aliança.

A candidatura de José Sarney, apesar de seus alvissareiros 14\% e um virtual empate em segundo lugar com FHC, teria grandes dificuldades em "decolar", pois seu governo havia sido muito mal avaliado, sendo considerado pela opinião pública como um governo altamente corrupto e responsável por uma das piores crises econômicas do país. Mas a candidatura de Orestes Quércia teria ainda menos chances. Além de ter apenas 7\% das preferências, Quércia tinha sido apontado por uma pesquisa do IBOPE no começo de 1993 como o "político corrupto mais popular do Brasil" ${ }^{40}$. Quércia era réu, desde 1991, de um processo de desvio de verbas na compra de equipamentos eletrônicos de Israel e também acabara de ser revelado que Quércia havia sido investigado por um órgão do governo militar, o qual constatou seu enriquecimento ilícito, sendo que ele só não teve seus bens confiscados por ter feito um acordo secreto com os militares ${ }^{41}$.

Tudo isso nos leva a crer que o pior resultado para o PMDB seria uma vitória petista e para evitá-la as melhores estratégias seriam apoiar o PSDB ou lançar a candidatura de José Sarney. No entanto, em maio, o PMDB decidiu lançar Quércia candidato a presidente. Como era esperado Quércia é derrotado obtendo apenas 4,38\% dos votos, atrás de Enéas Carneiro do até então desconhecido PRONA.

\footnotetext{
${ }^{40}$ Conforme o verbete "Orestes Quércia” do Dicionário Histórico-Biográfico Brasileiro da FGV/CPDOC. ${ }^{41}$ idem.
} 
Em cerca de um terço das decisões de entrada ${ }^{42}$ na disputa para o governo do estado no Brasil, entre 1994 e 2006, em $20 \%$ das decisões de entrada na disputa para prefeito ${ }^{43}$ entre 2000 e 2008 e em três das 35 decisões de entrada na disputa para Presidente entre 1994 e 2006, partidos grandes decidiram lançar candidatos que não tinham chance de vitória, isto é, houve falha de coordenação.

As falhas de coordenação têm impacto direto na representatividade do sistema. Imaginemos um sistema majoritário de um turno onde três candidatos disputam uma vaga. O candidato A, de direita, têm $40 \%$ dos votos e os candidatos B e C, de esquerda, têm $35 \%$ e $25 \%$ dos votos cada, respectivamente. Portanto, a maioria da população é de esquerda, mas por termos dois candidatos neste lado, o candidato vitorioso será o candidato da direita. Se o candidato C tivesse aberto mão de sua candidatura em favor de B a esquerda teria saído vitoriosa e o eleito representaria melhor o ponto de vista da população como um todo.

Neste capítulo buscaremos entender quais os fatores que influenciam a coordenação eleitoral, isto é, a decisão de um partido de lançar ou não um candidato. Para isso iremos rever alguns "modelos de entrada" que é como a literatura chama os modelos que procuram explicar a decisão de se lançar candidatos na disputa eleitoral. Nosso intuito é introduzir os principais conceitos e identificar as variáveis apontadas como determinantes para que um partido decida lançar um candidato. Em seguida iremos sugerir um modelo que utiliza características da organização partidária para explicar a coordenação eleitoral. Mostraremos

\footnotetext{
${ }^{42}$ Entendemos por "Decisão de Entrada" a decisão de um partido de lançar um candidato para disputar uma eleição em um determinado distrito e em um determinado ano. Assim, levando em conta apenas os sete partidos analisados teríamos $7 \times 27 \times 5=945$ decisões de entrada para a disputa pelo governo do estado, 7 X $5.445 \times 4=155.708$ decisões de entrada na disputa por prefeituras e 7 X $5=35$ decisões de entrada em disputas pela Presidência da República.

${ }^{43}$ Nas eleições de um turno.
} 
que a concentração partidária, medida pelo número de comissões provisórias em um partido, ajuda a explicar a decisão de um candidato entrar na disputa.

\subsection{Modelos de Entrada}

Conforme a Lei de Duverger (1958) sistemas majoritários de um turno levariam a existência de apenas dois partidos. A partir desta formulação vários autores estudaram a relação entre o número de partidos e as regras eleitorais. Cox (1997) mostrou que há um limite de M+1 para o número de partidos em um sistema, onde M é a magnitude do distrito eleitoral. A lógica por trás da Lei de Duverger é a de que um eleitor que apóia o terceiro colocado numa disputa pela única vaga em uma eleição majoritária de um turno irá abandonar este candidato e votará estrategicamente em um dos dois primeiros colocados para assim garantir o resultado mais próximo possível do seu resultado preferido. Deste modo o voto estratégico reduziria o número de candidatos a apenas dois.

O sistema eleitoral define o custo envolvido no lançamento de uma candidatura porque nos diz qual o número de votos mínimos necessários para garantir a obtenção de uma cadeira ou, inversamente, o número máximo de votos que serão "esterilizados", perdidos por não serem convertidos em cadeiras. $\mathrm{O}$ custo é inversamente proporcional à magnitude do distrito, isto é, ao número de cadeiras em jogo. Quanto menos cadeiras, maior a quantidade de votos para que um candidato garanta sua eleição e, portanto, maior o custo da campanha. Logo, em sistemas majoritários de um só turno este custo se eleva ao máximo. Sistemas proporcionais com alta magnitude baixam os custos. 
Duverger sugeriu também que as lideranças políticas, tendo em vista os custos envolvidos na decisão de entrar na disputa eleitoral, iriam antecipar a ação estratégica dos eleitores deixando de lançar candidatos. As lideranças ao preverem que seus candidatos iriam sofrer o efeito da deserção causada pelo voto estratégico iriam preferir oferecer seus recursos para um candidato viável e, assim, aumentar as chances de vitória de uma política mais próxima a sua.

Desde Duverger vários autores procuraram elaborar modelos formais que explicassem a decisão de entrar ou não na competição eleitoral (Palfrey, 1984, Greenberg e Shepsle, 1987, Feddersen, Sened e Wright, 1990, Weber, 1992 e 1998, Osborn e Slivinski, 1996, Fey, 1997, Cox, 1997, Golder, 2004, Laver e Shilperoord, 2007). Nesta seção iremos rever alguns destes modelos procurando identificar neles as variáveis consideradas determinantes para que um partido lance um candidato.

A questão da decisão de lançar uma candidatura aparece em Palfrey (1984) não como uma extensão do modelo de Duverger, mas sim para resolver um problema no teorema do eleitor mediano conforme aplicado por Downs (1999). No modelo de Downs candidatos concorrem pelo voto de eleitores cujas preferências se distribuem uniformemente em uma dimensão que corresponde a certa política pública. Os candidatos devem lançar propostas adotando alguma posição nesta dimensão e os eleitores escolhem o candidato cuja posição é mais próxima à sua. Downs assume que há apenas dois candidatos e mostra que, em um sistema majoritário de turno único, os dois candidatos irão convergir: suas propostas atenderão a vontade do eleitor mediano. O que Palfrey mostra é que se a premissa de que há apenas dois candidatos for modificada não haverá convergência no ponto mediano. 
Para Palfrey o teorema do eleitor mediano só se aplicaria quando não é possível a entrada de um terceiro candidato na competição eleitoral. Segundo este autor se fosse possível a entrada de um terceiro candidato ele poderia se posicionar a uma pequena distância de um dos outros candidatos "roubando" seus votos. Assim se dois candidatos se posicionarem no ponto do eleitor mediano sempre haverá um terceiro candidato na competição.

Como evidências empíricas colhidas por Palfrey mostravam que em sistemas majoritários simples (de um só turno) era rara a existência de um terceiro candidato ele concluiu que, nos casos reais, os dois candidatos presentes na disputa não deveriam estar posicionados no ponto ideal do eleitor mediano, o que contraria o estabelecido por Downs. O modelo de Palfrey procura definir qual seria o ponto de equilíbrio, isto é, a distância entre os candidatos que impediria a entrada de um terceiro.

Conforme Palfrey se dois candidatos estiverem posicionados juntos no ponto do eleitor mediano, um terceiro candidato irá maximizar seus votos ao "copiar" um deles adotando uma posição ligeiramente mais extremada (ver figura 4.1a). Neste caso, antes da entrada do candidato $\mathrm{C}$ os candidatos A e B detinham $50 \%$ dos votos cada. Com a entrada de $\mathrm{C}$, em um ponto um pouco mais à esquerda que o mediano, ele irá abocanhar todos os votos à esquerda deste ponto, digamos $48 \%$, vencendo os outros dois que dividem os restantes $52 \%$ ficando com $26 \%$ cada.

Por outro lado, se dois candidatos se posicionarem muito distantes um do outro, o terceiro candidato maximizará seus votos ao adotar uma posição mais central (figura 4.1b). Suponhamos que o eleitor A se posiciona de tal modo que apenas $10 \%$ dos eleitores estejam ainda mais à esquerda dele e suponhamos que o candidato B esteja posicionado de 
tal modo que apenas $10 \%$ dos eleitores estejam à sua direita. Antes de $\mathrm{C}$ entrar no ponto mediano cada um destes candidatos têm $50 \%$ dos votos pois todos os eleitores que estão à esquerda do ponto mediano preferem A a B e vice versa.Quando C entra no ponto mediano ele irá abocanhar 40\% dos votos pois os eleitores que estão entre A e C irão se dividir, 20\% irão preferir A e $20 \%$ irão preferir C. O mesmo acontece com B. Tanto A quanto B ficarão com apenas $30 \%$ dos votos perdendo a eleição.

FIGURA 4.1 - POSIÇÕES ASSUMIDAS PELOS CANDIDATOS NO MODELO DE PALFREY (1984).

Figura 4.1a

$\begin{array}{r}\text { C } \text { B }^{\mathbf{A}} \\ \hline\end{array}$

Figura $4.1 \mathrm{~b}$

A 
Palfrey sugere que os candidatos já estabelecidos antecipam o raciocínio do terceiro candidato e não se posicionam nem muito perto um do outro, para não serem "copiados" pelo entrante, e nem se posicionam muito distantes, para impedir que o entrante se coloque no meio e acabe se beneficiando com a maior parte dos votos (figura 4.1c). Neste último caso temos uma situação de equilíbrio onde o terceiro candidato sempre perde e os dois partidos não convergiriam no eleitor mediano ${ }^{44}$.

As principais premissas do modelo de Palfrey são: há apenas um entrante, ele sempre entra na disputa e não há voto estratégico. A premissa de que o terceiro candidato sempre entra na disputa decorre de outra premissa, a de que o candidato se preocupa apenas em maximizar a quantidade de votos e não em quem vence as eleições. Um candidato que se preocupa apenas em maximizar o número de votos entraria na disputa mesmo que esteja incerto quanto à exata distribuição de votos. Neste modelo, mais do que a chance de vencer a eleição, a variável chave é a posição dos partidos.

Estendendo o modelo de Palfrey, Feddersen et.al. (1990) propõe um modelo de entrada ${ }^{45}$ onde os candidatos decidem se entram ou não, conforme a probabilidade de vitória e a relação entre o benefício (b) de se ganhar a eleição e o custo (c) de se lançar candidato.

Neste modelo um candidato só entra na disputa se tiver chance de ser eleito e só há equilíbrio quando todos os candidatos têm a mesma chance de ser eleito, pois não seria racional a entrada de um candidato com menos chance que os outros. Nestas condições o número de candidatos se torna igual a $\mathbf{b} / \mathbf{c}$ podendo variar entre 1 (quando $\mathbf{b}=\mathbf{c}$ ) e infinito.

\footnotetext{
${ }^{44}$ Palfrey mostra que o equilíbrio para os dois partidos dominantes $A$ e $B$ se daria nas posições $\left(\theta_{A}, \theta_{B}\right)=(1 / 4$, $3 / 4)$.

${ }^{45}$ Este modelo também se aplica apenas ao caso de eleições em sistemas majoritários de um só turno.
} 
Assim o modelo de Feddersen et. al., só se aproxima da Lei de Duverger quando b/c $<3$

(Cox, 1997). Quando b/c $\geq 3$ o número de partidos cresce indefinidamente.

Osborn e Slivinski (1996) estendem o trabalho de Feddersen mostrando que, além da relação entre o benefício de ser eleito e o custo da eleição, o tipo de sistema eleitoral tem grande importância para o número de candidatos em equilíbrio. Em sistemas majoritários simples ocorre equilíbrio com dois candidatos, já o número de candidatos em sistemas majoritários em dois turnos tende a ser maior, resultados estes que estão de acordo com as previsões de Duverger.

No modelo de Osborn e Slivinski existem apenas cidadãos ${ }^{46}$ que têm preferências distribuídas uniformemente em uma dimensão. Estes cidadãos viram candidatos e entram na disputa eleitoral conforme o custo de participar da disputa, o benefício de se tornar governo e a posição dos demais candidatos. Neste modelo as situações de equilíbrio variam com o sistema eleitoral adotado.

Além de abordar diretamente a Lei de Duverger, incorporando os efeitos do sistema eleitoral, os autores também dão um passo além com relação aos modelos anteriores ao tornar endógeno o número de candidatos na competição. No modelo, qualquer cidadão vira candidato conforme a distribuição dos parâmetros b, $\mathbf{c}$, e dos pontos ideais dos candidatos.

Os modelos de Palfrey, Feddersen e Osborn e Slivinski têm em comum o fato dos candidatos se importarem apenas com os custos e benefícios envolvidos na disputa e com as chances de vitória. As chances de vitória dependeriam apenas das posições que os

\footnotetext{
${ }^{46}$ O modelo desenvolvido por Osborn e Slivinski entra na categoria dos citzen-candidate models desenvolvido também, de forma independente, por Besley e Coate (1995).
} 
candidatos adotam no espaço político neste sentido estes são modelos neutros. Um modelo espacial é neutro se um candidato A e um candidato B ao trocar de posição um com outro também trocam sua expectativa de vitória, isto é, no modelo neutro a chance de vitória depende apenas da posição adotada pelo candidato e não de algum atributo extra-eleitoral do candidato. Portanto, em um modelo neutro qualquer candidato vê suas chances de vitória iguais a de qualquer outro antes de adotarem alguma posição e, portanto, não tem porque imaginar que será a vítima do voto estratégico.

Cox (1997) elabora um modelo de entrada não neutro onde há "vantagens não espaciais", isto é, alguns candidatos são percebidos pelos eleitores como tendo mais chances de ganhar a eleição. Assim, antes mesmo de entrar na disputa um candidato sabe se poderá vir a ser vítima do voto estratégico e, neste caso, desistir da competição.

Cox sugere que a viabilidade de um candidato depende do endosso de um grande partido, isto é, candidatos lançados por partidos grandes atrairiam mais eleitores e, portanto, teriam maior probabilidade de vitória. $\mathrm{O}$ endosso de um partido funcionaria como um mecanismo de coordenação para os eleitores, sem este endosso não seria possível distinguir entre uma “superabundância de candidatos similares" (COX, 1997:159). Como o endosso do partido ajuda a coordenação dos eleitores em torno de candidatos, existiria a tendência de, com o tempo, estes partidos passarem a contar com o apoio habitual de um conjunto de eleitores. Esse apoio habitual daria aquela "vantagem não espacial", isto é, antes mesmo de se posicionar no espaço político os competidores já saberiam as chances de vitória de cada um e coordenariam suas ações. 
Cox propõe que a probabilidade de um candidato procurar o endosso de um partido no lugar de sair da disputa ou de se lançar de modo independente ${ }^{47}$, varia com a permeabilidade do processo de endosso, isto é, da facilidade com que um pretendente consegue uma vaga por aquela legenda e da vantagem que a legenda dá ao candidato. Se a permeabilidade for alta ele irá preferir disputar a indicação por uma legenda forte do que se lançar sob uma legenda com menores chances. Segundo Cox este mecanismo explicaria porque nos Estados Unidos as primárias contribuiriam para, citando Epstein, a “distinctively American weakness of third parties" (COX, 1997: 167).

O modelo de Cox, ao introduzir os efeitos do voto estratégico nos modelos de entrada, incorpora uma nova variável, a permeabilidade do processo de endosso de partidos estabelecidos. Aparece aqui, pela primeira vez, a relação entre o número de partidos e a organização partidária, ainda que de forma pouco definida ${ }^{48}$. Quanto mais descentralizado o processo de endosso, maior a permeabilidade de um partido e menor a probabilidade de um terceiro partido entrar na disputa. Assim, além da posição dos partidos, das chances de vitória, do custo de se lançar um candidato e do prêmio que a vitória traz, os modelos de entrada deveriam levar em conta as vantagens do endosso dos partidos e sua permeabilidade.

\footnotetext{
${ }^{47}$ Cox está claramente pensando com base no modelo americano onde há candidatura independente. Existiria uma quarta opção: entrar na disputa com o objetivo de "protesto" ou de "chantagem". Embora Cox considere esta possibilidade ele não a inclui na análise.

${ }^{48}$ Não há uma definição operacional para a variável permeabilidade. Algumas vezes ela significa a facilidade de participar do processo de seleção de candidatos, como no caso dos EUA, outras vezes apenas do uso da sigla, como na Colômbia. Além disso há uma certa confusão quanto ao tipo de partido que seria procurado para dar seu endosso. Cox afirma (1997:171) que o efeito do endosso só funcionaria em sistemas partidários estruturados no sentido dado por Sartori, o que pressupõe, como vimos no capítulo 2, partidos de massa, mas, ao mesmo tempo, seus exemplos de partidos permeáveis são todos com partidos considerados pela literatura como, no máximo, catch-all parties.
} 
A conclusão que se pode tirar dos modelos de entrada analisados é a de que as principais variáveis explicativas para a coordenação eleitoral são a chance de vitória, o custo de se lançar candidato, os benefícios auferidos com a vitória, a posição das políticas oferecidas pelos partidos e, no caso de Cox, o grau de permeabilidade dos partidos. Na próxima seção iremos procurar entender a decisão dos partidos de lançar candidatos nas eleições majoritárias no Brasil a partir destas variáveis.

\subsection{Testando os modelos de entrada nas eleições majoritárias}

As alianças eleitorais para cargos majoritários são quase que a regra nas eleições para prefeito, governador e presidente. Nas 11.043 eleições para prefeito das quais temos informações sobre coligações ${ }^{49}, 77 \%$ dos candidatos e $90 \%$ dos eleitos estavam coligados. Nas 108 eleições para o governo de estado entre 1994 e 2006, 55\% dos candidatos e $93 \%$ dos eleitos fizeram coligações. Já nas cinco eleições para presidência das 54 candidaturas 17 eram coligações e em nenhum caso o vitorioso venceu sozinho.

O Quadro 4.1 mostra o número de vezes que os partidos grandes fizeram coligações nas disputas para os três níveis de governo. Embora na disputa pela presidência dois partidos (PDT e PDS/PPB/PP) se coligaram em menos da metade das vezes em que participaram das eleições, quase sempre os grandes partidos estabelecem alianças eleitorais.

\footnotetext{
${ }^{49}$ Essas eleições são as ocorridas nos anos 2000 e 2004. Fonte: TSE.
} 


\section{TABELA 4.1 - NÚMERO DE VEZES QUE UM PARTIDO DECIDIU SE COLIGAR NAS ELEIÇÕES PARA PREFEITO, GOVERNADOR E PRESIDENTE ENTRE 1989 E 2008}

\begin{tabular}{lrr|rr|rr} 
& \multicolumn{2}{c|}{ Prefeito } & \multicolumn{2}{c|}{ Governador } & \multicolumn{2}{c}{ Presidente } \\
\cline { 2 - 7 } & $\mathrm{N}$ & $\%^{\mathrm{b}}$ & $\mathrm{N}$ & $\%$ & $\mathrm{~N}$ & $\%$ \\
\hline PT & 5899 & $64 \%$ & 128 & $96 \%$ & 5 & $100 \%$ \\
PDT & 6061 & $96 \%$ & 92 & $86 \%$ & 2 & $40 \%$ \\
PMDB & 9091 & $89 \%$ & 108 & $84 \%$ & 2 & $67 \%$ \\
PSDB & 8321 & $93 \%$ & 108 & $91 \%$ & 4 & $80 \%$ \\
PTB & 7425 & $96 \%$ & 105 & $96 \%$ & 3 & $75 \%$ \\
PFL & 8619 & $93 \%$ & 124 & $96 \%$ & 2 & $67 \%$ \\
PDS/PP & 7376 & $94 \%$ & 111 & $97 \%$ & 1 & $33 \%$ \\
\hline \hline
\end{tabular}

Fonte: TSE para os dados municipais. Nicolau, Jairo (2009) para os dados estaduais e fec ${ }^{a}$ Os dados se referem à 11.043 eleições para prefeito em 2000 e 2004, 135 eleições para governador em 1990, 1994, 1998, 2002 e 2006 e a 5 eleições para presidente em 1989, 1994, 1998, 2002 e 2006.

${ }^{\mathrm{b}} \mathrm{O}$ percentual é sobre o núemero de eleições que o partido participou

Esses dados corroboram o que vimos no Capítulo 3, isto é, as elites políticas dos grandes partidos costumam estabelecer coordenação pré-eleitoral. Nesta seção vamos voltar a atenção para os casos onde a coordenação não ocorreu. Iremos examinar apenas as eleições para o governo de estado.

Seguindo os modelos de entrada analisados na seção anterior, há falha de coordenação estratégica por parte das elites políticas toda vez em que um candidato sem chance de vitória entra na disputa. Portanto, para identificar se houve falha de coordenação devemos verificar a quantidade de vezes que um partido lançou um candidato sem ter chance de vitória. Para isso temos que, antes de tudo, definir chance. 
Uma maneira de definir de chance se baseia nos resultados das pesquisas pré-eleitorais ${ }^{50}$, mas como infelizmente não dispomos destes dados para as todas as eleições regionais e municipais precisamos estabelecer uma medida que substitua estas pesquisas.

Outra forma das lideranças partidárias verificarem se têm chance é olhando para eleição anterior $^{51}$. Há uma correlação entre o desempenho na eleição anterior e o resultado das primeiras pesquisas eleitorais ${ }^{52}$. Essa correlação se deve ao fato das pesquisas refletirem um recall da última eleição, isto é, os eleitores se lembram dos candidatos que participaram daquela disputa e citam mais estes candidatos. Essas pesquisas também refletem a aprovação do governante atual, ele próprio um candidato da última eleição. A partir da eleição de 1998, com a possibilidade da reeleição, algumas das disputas eleitorais se tornaram "plebiscitos" e se concentraram nas figuras do governador eleito e do candidato da oposição, normalmente do partido que lhe fez oposição na campanha anterior.

Assim acreditamos que o desempenho na eleição anterior pode ser usado para definir a chance de vitória. Consideramos um candidato com chance de ser eleito aquele cujo partido obteve mais de $10 \%$ de votos na eleição anterior para o mesmo cargo.

\footnotetext{
${ }^{50}$ Fey (1997) construiu um modelo de entrada onde a chance de vitória é dada pelos resultados de pesquisas pré-eleitorais. As pesquisas também têm papel preponderante no modelo baseado em agentes de Kollman et. al. (1992) e a influência de pesquisas eleitorais na decisão do voto é constatada em experimentos por Forsythe et. al.(1993).

${ }^{51}$ A decisão de entrar em uma disputa eleitoral condicionada ao desempenho na eleição anterior já aparece em Soares (2001). Soares diz que "onde o candidato ou partido acreditar, sem margem para dúvidas, que vencerá as eleições somente com seus votos, ele não entrará em alianças com outras forças eleitorais" (SOARES, 2001:144). Os exemplos que corroboram esta hipótese são baseados na votação recebida em eleições passadas, como o caso do PSD que não se coliga em 1950 nos estado em que, em 1945, recebeu a maioria dos votos.

${ }^{52}$ Correlacionando os resultados das pesquisas pré-eleitorais para Presidente da República e os resultados da eleição imediatamente anterior entre 1994 e 2006 obtivemos um coeficiente de 0,81, isto é, um partido que teve um bom desempenho numa eleição costumava aparecer com vantagens nas pesquisas eleitorais nas eleições seguintes. Selecionamos as pesquisas realizadas antes das convenções partidárias por serem elas as prováveis balizadoras da decisão de lançar candidato, utilizamos as pesquisa do instituto Datafolha disponíveis em http://datafolha.folha.uol.com.br (último acesso: 17/03/2009).
} 
As Tabelas 4.2 e 4.3 mostram quantas vezes um partido decidiu lançar um candidato às eleições para o governo do estado e para a prefeitura, respectivamente, conforme as chances de vitória $^{53}$. A Tabela 4.2 mostra que em $2 / 3$ de todas as 945 decisões de entrar ou não na disputa para o governo do estado, partidos que não tinham chance de vencer a disputa optaram por não lançar candidato, a mesma proporção daqueles que, diante da possibilidade de vitória, decidiram por entrar na disputa. No entanto mais de $30 \%$ de candidatos sem chance foram lançados e a mesma quantidade de candidatos viáveis deixou de se candidatar.

TABELA 4.2 - DECISÃO DE ENTRAR NA DISPUTA PARA GOVERNADOR DE ESTADO CONFORME CHANCE DE VITÓRIA

\begin{tabular}{lrr|r} 
& Sem chance (\%) & Com Chance (\%) & Total geral (N) \\
\hline Não Entrou (\%) & 0,66 & 0,39 & 542 \\
Entrou (\%) & 0,34 & 0,61 & 403 \\
\hline Total geral (N) & 650 & 295 & 945 \\
\hline \hline
\end{tabular}

Fonte: Nicolau, Jairo. Dados Eeleitorais do Brasil (82-06) in http://jaironicolau.iuperj.br/banco2004.html .

Nas eleições municipais estes números são menos dramáticos, mas ainda significativos: em $20 \%$ dos casos houve falha de coordenação. Também é grande a proporção de partidos que deixam de lançar candidatos mesmo quando obteve uma votação expressiva nas últimas eleições $(40 \%)$.

\footnotetext{
${ }^{53}$ Nas eleições presidenciais houve falha de coordenação apenas três vezes: o PMDB e o PP em 1994 e o PDT em 2006. Em nenhum caso um candidato com chances deixou de lançar um candidato. Isso mostra que nas eleições presidenciais, mais que nas outras, a coordenação é a regra. No entanto o reduzido número de casos impede uma análise mais conclusiva e, portanto, não levaremos em conta as eleições presidências na análise que segue.
} 
TABELA 4.3 - DECISÃO DE ENTRAR NA DISPUTA PARA PREFEITO CONFORME CHANCE DE VITÓRIA

\begin{tabular}{lrrr} 
& Sem chance (\%) & Com Chance (\%) & Total geral (N) \\
\hline Não Entrou (\%) & 0,80 & 0,40 & 25.655 \\
Entrou (\%) & 0,20 & 0,60 & 12.333 \\
Total geral (N) & 26.589 & 11.399 & 37.988 \\
\hline \hline
\end{tabular}

Fonte: TSE para dados municipais. Nicolau, Jairo Dados Eleitorais do Brasil (1982-2006), in http://jaironicolau.iuperj.br/banco2004.html (último acesso em 13/04/2009)

Nossa intenção ao testar os modelos de entrada é justamente identificar os motivos que levam um candidato sem chancese lançar na disputa, isto é, por que há falha de coordenação entre as elites políticas.

Passemos então ao teste dos modelos de entrada. Como vimos na seção anterior as principais variáveis utilizadas pelos modelos de entrada são:

- A probabilidade de vitória (que definimos como chance);

- O custo de se entrar na disputa;

- O benefício obtido com a vitória;

- A posição do partido;

- A permeabilidade dos partidos.

No modelo que iremos testar consideramos os custos e benefícios como comuns a todos os candidatos pois os custos se referem à magnitude do distrito e os benefícios se referem à conquista da Presidência, Governo do Estado ou Prefeitura. Assim trataremos custos e benefícios como constantes e, portanto, não iremos incluí-las no modelo a ser estimado. 
Como já definimos chance passaremos a definir as variáveis posição e permeabilidade partidária.

\section{A posição do partido}

Nos modelos de entrada vistos acima a posição dos partidos importava na medida em que impediam ou não a entrada de novos candidatos. Nos modelos de Palfrey (1994) e Osborn e Slivinski (1996) existem alguns pontos em que ocorre equilíbrio com dois partidos. Por um lado isso ocorre porque um partido sem chance de vitória que tem a mesma posição que um partido com chance deixará de entrar e passará a apoiar esse partido. Por outro lado um partido eqüidistante de dois competidores com chance deixará de entrar na disputa, pois a quantidade de votos que poderá amealhar não lhe dará a vitória ${ }^{54}$,

Portanto, a distância com relação aos candidatos com chance parece ser importante para a decisão de entrada. Definiremos a distância ao partido com chance mais próximo como $D_{c(\min )}$ e a distância ao partido com chance mais distante como $D_{c(\max )}$.

Nossa medida de posição é a proximidade. Definimos proximidade como a distância entre a posição do partido e a posição do candidato com chance mais próximo, isto é proximidade $=D_{c(\min )}$. Essa medida nos ajuda a testar a hipótese de que a existência de um candidato com chance ideologicamente próximo impediria a entrada de um candidato sem chance, isto é, se um candidato não tem chance e há outro candidato do mesmo espectro ideológico na disputa ele deixa de entrar para apoiar este candidato, do contrário ele poderá entrar

\footnotetext{
${ }^{54}$ A não ser que o objetivo do partido seja prejudicar um dos concorrentes (Osborn e Slivinski, 1996) ou criar reputação (Cox, 1997).
} 
mesmo com pouca chance. Assim esperaríamos que quanto maior a proximidade maior a chance de um candidato não entrar na disputa.

As posições dos partidos foram obtidas por meio do uso da técnica do w-nominate utilizando como matriz as votações nominais na câmara dos deputados nas $49^{\mathrm{a}}, 50^{\mathrm{a}}, 51^{\mathrm{a}} \mathrm{e}$ $52^{\mathrm{a}}$ legislaturas. Como o $w$-nominate nos dá as posições individuais de cada deputado consideramos como a posição do partido a média das posições dos deputados ${ }^{55}$. A Tabela 4.4 mostra essas posições para cada legislatura ${ }^{56}$.

TABELA 4.4 - MÉDIA E VARIÂNCIA DAS POSIÇÕES DOS DEPUTADOS FEDERAIS DOS PRINCIPAIS PARTIDOS BRASILEIROS NAS 49ạ, 50å, 51a E 52 a LEGISLATURAS.

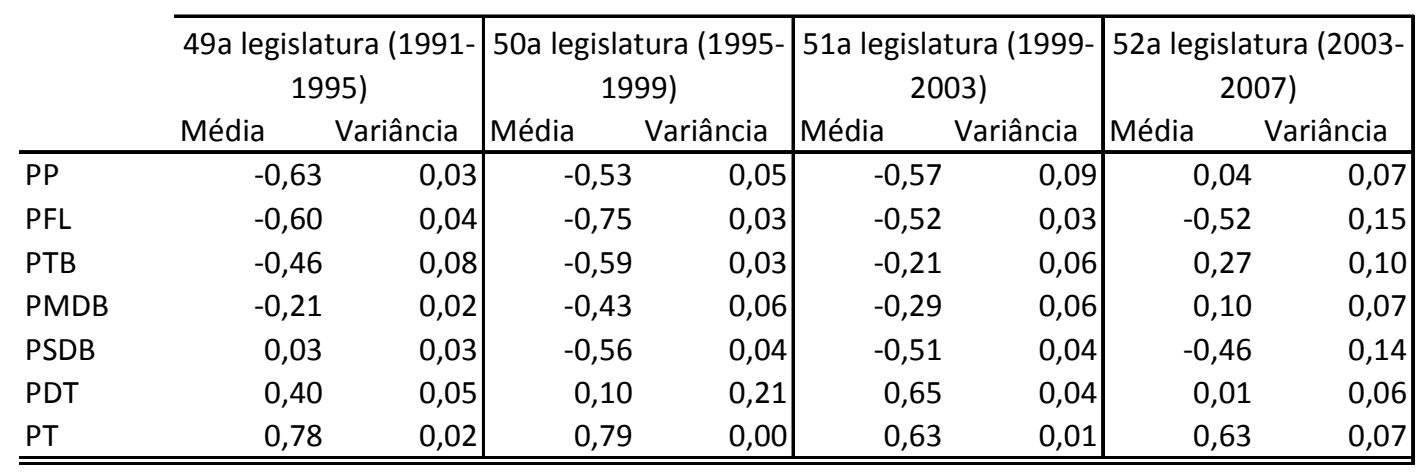

Fonte: Limongi, Fernando Banco de dados de Votações nominais na Câmara dos Deputados

Além da proximidade também iremos verificar se partidos de esquerda lançam mais candidatos que partidos de direita. Para isso iremos utilizar uma variável dummy com valor 1 se o partido for de esquerda e zero do contrário. Chamaremos esta variável de Esq e esperamos um sinal positivo para seu coeficiente indicando que se um partido for de esquerda maior a probabilidade dele entrar na disputa independente de sua chance de vitória.

\footnotetext{
${ }^{55}$ Consideramos apenas a posição na primeira dimensão que, por sua vez é a mais significativa.

${ }^{56}$ Apesar destes dados se referirem a Câmara de Deputados, a posição dos partidos no nível regional parece ser consistente com a distribuição no nível nacional, o que justifica seu uso na análise das eleições para o governo do estado. Nas eleições municipais não utilizaremos as variáveis posicionais.
} 


\section{A permeabilidade dos partidos.}

No modelo de Cox (1997) partidos e candidatos são entes separados e a permeabilidade dos partidos significa a probabilidade de um candidato conseguir o endosso de um partido. Para Cox um candidato só teria chance de vencer uma disputa se conseguisse o endosso de um partido de peso. A permeabilidade seria a facilidade com que o candidato consegue esse endosso.

Na visão de Cox os partidos têm peso quando têm raízes na sociedade e quando possui o "monopólio do processo de endosso" junto a um segmento da população, isto é, quando este segmento vota apenas conforme a orientação do partido e não de outros meios como jornais, líderes de opinião, etc. (COX, 1997:160). Isso mostra como a visão de Cox ainda se prende ao paradigma do partido de massa e ele chega a afirmar que este modelo só funciona em sistemas partidários estruturados, conforme a concepção de Sartori (COX, 1997: 171). São poucos os partidos em sistemas estruturados cujo processo de escolha de candidatos seja descentralizado (RAHAT e HAZAN, 2001) e, por isso, Cox tem dificuldades em mostrar casos em que há permeabilidade $e^{57}$

Certamente no Brasil, assim como em um número grande de polities, não há partidos que consigam o "monopólio do processo de endosso" e que sejam permeáveis. No entanto

\footnotetext{
${ }^{57}$ Cox se restringe a exemplos de partidos cujo processo de seleção de candidatos é totalmente aberto. Esses são casos raros e é por isso que ele se concentra nos casos dos EUA, da Colômbia e do Uruguai onde qualquer agrupamento pode reinvidicar uma legenda. Na realidade na maior parte dos partidos descentralizados o endosso a uma candidatura é fruto de intensa luta intra-partidária que se dá conforme regras precisas que, em geral, dificultam e criam custos para o processo de nomeação. Por outro lado partidos centralizados tem maior liberdade de nomeação e maior facilidade em estabelecer acordos (GUARNIERI, 2005 , RAHAT e HAZAN, 2001,TSEBELIS, 1998).
} 
podemos modificar o conceito de Cox para lidar com a influência da organização partidária na decisão de entrada na arena eleitoral.

O modelo de Cox separa os pré-candidatos e os partidos, isto é, um pré-candidato pode escolher o partido pelo qual pretende sair e escolherá aquele com maior chance de vitória e onde há maior chance de ser nomeado candidato. No nosso modelo não há tal separação, os candidatos devem escolher seu partido bem antes das eleições ${ }^{58}$. Portanto não são os candidatos individualmente que escolhem se entram ou não nas disputas, mas sim os partidos por meio de suas lideranças, especificamente as lideranças nacionais.

As lideranças partidárias, assim como os candidatos individuais no modelo de Cox, conhecem a chance de vitória de seus partidos e se defrontam com as mesmas opções eleitorais: a) não entrar na disputa; b) entrar na disputa junto com um partido com mais chances; c) entrar na disputa sem se aliar, na esperança de se tornar viável; d) entrar na disputa para prejudicar um determinado partido, retirando seus votos.

As funções de utilidade são, portanto, as mesmas que aquelas desenvolvidas por Cox. A diferença é que o que importa não é a permeabilidade do partido, mas sim a facilidade com que os partidos decidem fazer as alianças e as vantagens que se pode obter com elas. Vimos no Capítulo 2 que essa facilidade depende do controle que as lideranças têm da organização partidária. Vimos que quanto mais organizado o partido, em termos de número de diretórios constituídos, menor o controle que as lideranças possuem sobre a convenção. Ao contrário, quanto mais comissões provisórias tem um partido maior o controle das lideranças sobre as convenções. Assim, iremos substituir o conceito de permeabilidade pelo de concentração

\footnotetext{
${ }^{58}$ No Brasil um candidato deve estar filiado a pelo menos um ano ao partido pelo qual pretende concorrer. Em outros países as exigências são até maiores (GUARNIERI, 2004).
} 
partidária, uma proxy do controle das lideranças sobre a decisão de se coligar, definido como a proporção de comissões provisórias sobre o total de diretórios do partido.

\section{Testando os modelos de entrada nas eleições para o governo do estado}

A variável dependente do modelo é a decisão de entrada na disputa pelo governo do estado.

Os dados utilizados se referem a 328 decisões dos sete grandes partidos de lançar candidatos em 13 estados da federação ${ }^{59}$.

O modelo que propomos é:

ENTRgov $=\beta_{0}+\beta_{1}$ CHANCE $+\beta_{2}$ PROX $+\beta_{3}$ ESQ $+\beta_{4}$ CONPART $+\varepsilon$

Onde ENTRgov é 1 se o partido lançou candidato ao governo do estado e 0 do contrário, CHANCE é 1 se o partido tiver obtido mais de $10 \%$ de votos na eleição anterior e 0 do contrário, PROX é a distância com relação ao partido com chance mais próximo - $D_{c(\min )}$, ESQ é 1 se o partido for de esquerda ${ }^{60}$ e 0 do contrário, e CONPART é o número de comissões provisórias dividido pelo número de diretórios.

Como a variável dependente é dicotômica iremos utilizar o modelo logit. O modelo foi calculado utilizando-se o método proposto por King et. al.(2008). Este método envolve a aproximação por máxima verossimilhança e o uso dos coeficientes para simular estatisticamente as quantidades de interesse e medidas de incerteza. Para realizar os

\footnotetext{
${ }^{59}$ Isso se deve a ausência de informações sobre concentração partidária para todos os estados brasileiros. Além disso não temos informações sobre o número de diretórios do PTB e o PDT no Acre no período considerado.

${ }^{60}$ Consideramos como de esquerda o PT e o PDT.
} 
cálculos utilizamos o modelo logit do pacote Zelig (IMAI, KING E LAU, 2008) que roda no programa de estatística $R$.

A Tabela 4.5 mostra os resultados do modelo.

TABELA 4.5 - COEFICIENTES ESTIMADOS, ERROS PADRÃO, VALORES DE |Z| E SIGNIFICÂNCIA PARA O MODELO DE ENTRADA PARA AS ELEIÇÕES PARA O GOVERNO DO ESTADO.

\begin{tabular}{lrrrl} 
& Coeficiente & Erro Padrão & \multicolumn{1}{c}{$\mathrm{Z}$} & $\operatorname{Pr}(>|z|)$ \\
\hline Intercepto & 0,00809 & 0,29675 & 0,03000 & 0,97800 \\
Chance & 1,35198 & 0,30231 & 4,47000 & 0,00001 \\
Prox & $-0,11083$ & 0,63348 & $-0,17000$ & 0,86100 \\
Esq & 0,75772 & 0,29743 & 2,55000 & 0,01100 \\
Conpart & $-1,60864$ & 0,35746 & $-4,50000$ & 0,00001
\end{tabular} ***

Códigos de significância: $0^{(* * * \prime} 0.001^{* * \prime} 0.01^{* \prime \prime} 0.05$ '? $0.1^{\prime \prime} 1$

Desvio modelo nulo: 453.72 on 327 graus de liberdade

Desvio residual: 376.18 on 322 graus de liberdade

AIC: 386.2

Os resultados mostram que embora a variável Prox tenha o sinal esperado, indicando que a presença de um partido próximo ideologicamente faz com que caia a probabilidade de entrada na competição eleitoral ela não é siginificativa.

Já as variáveis Chance, Esq e Conpart são significativas e têm o sinal esperado. Um partido que teve mais de $10 \%$ de votos na última eleição tem maior probabilidade de lançar um candidato do que um partido que obteve menos de $10 \%$ dos votos ou se coligou na última eleição. Esse resultado está absolutamente de acordo com os modelos de entrada considerando os custos de se entrar na disputa e os benefícios auferidos com a conquista do 
governo como iguais para todos. Um partido de esquerda também tem maior probabilidade de entrar na disputa independente de sua chance ou tipo de organização ${ }^{61}$.

O resultado mais relevante do ponto de vista substantivo é a constatação de que, quanto mais centralizado um partido, maior a probabilidade dele não lançar um candidato. Este resultado mostra a relação entre organização partidária e competição eleitoral prevista por Cox (1997), mas, até então, ainda não testada. O Gráfico 4.1 mostra a relação entre a probabilidade de lançar candidato e a concentração partidária controlando pela chance de vitória com um intervalo de confiança de $95 \%$.

GRÁFICO 4.1 - DISTRIBUIÇÃO DA PROBABILIDADE DE LANÇAR CANDIDATO CONFORME O GRAU DE CONCENTRAÇÃO PARTIDÁRIA E PELA CHANCE DE VITÓRIA

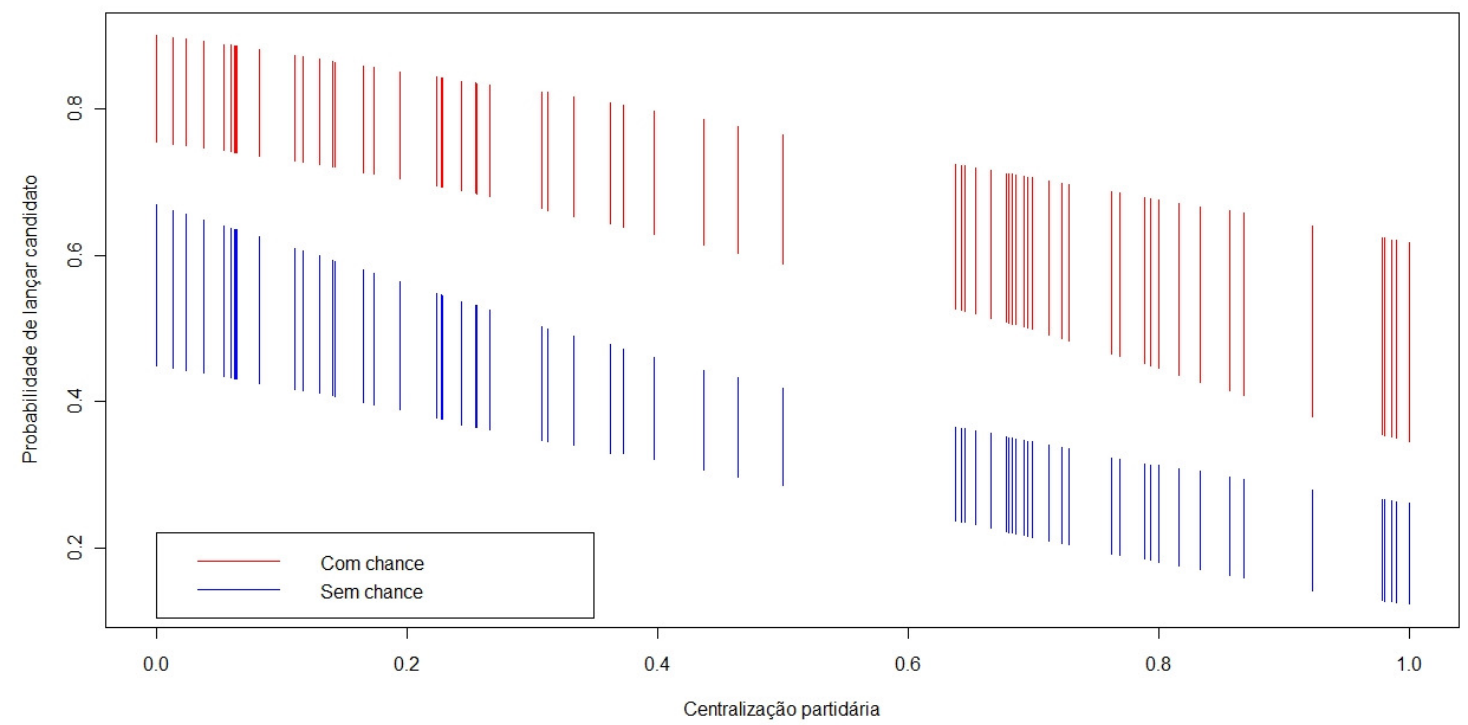

${ }^{61}$ Lembramos que consideramos como partidos de esquerda o PT e o PDT. O primeiro foi considerado, na análise que fizemos no Capítulo 2 , um partido poliárquico e o segundo um partido oligárquico. 
Neste gráfico vemos que quando a concentração partidária está perto de zero, isto é, quando as lideranças partidárias não têm controle direto sobre as decisões do partido tendo que se submeter à vontade da maioria, a probabilidade de lançar candidatos, quando o partido não tem chance, é próxima a 60\%. Já quando as decisões partidárias estão nas mãos das lideranças, a probabilidade de lançar candidato cai pela metade ficando próxima a $25 \%$.

Também é interessante verificar que, mesmo quando um partido tem chance de vitória, a probabilidade de entrar na disputa fica em torno de $60 \%$ em partidos centralizados enquanto que isto ocorre mais de $80 \%$ das vezes em partidos descentralizados.

Portanto, os dados ajudam a entender o aparente paradoxo de candidatos sem chance entrarem na disputa eleitoral e candidatos com chance deixarem de fazê-lo sem ter que modificar as premissas sobre a motivação dos $\operatorname{partidos}^{62}$.

Partidos descentralizados podem lançar candidatos sem chance por conta da maneira como as decisões são tomadas no seu interior. Quanto mais proporcionais as regras de tomada de decisão, isto é, quanto mais equilibradas forem as forças nas disputas intra-partidárias mais incertos serão os resultados destas disputas, sendo que resultados sub-ótimos têm a mesma probabilidade que resultados ótimos. Exemplos disso são a candidatura Quércia em 1998 pelo PMDB e o "suicídio político" dos militantes trabalhistas ingleses analisado por Tsebelis (1998).

Para deixar ainda mais evidente o impacto da centralização partidária na decisão de lançar candidatos mostramos, na Tabela 4.6, as primeiras diferenças e as razões de risco (em um

\footnotetext{
${ }^{62}$ Geralmente este paradoxo é resolvido atribuindo-se uma motivação diferente da de conquistar o poder, como protesto, chantagem ou promoção da sigla. Embora estes motivos possam ser atribuídos a partidos pequenos eles não são facilmente aplicados a partidos grandes conforme definido mais acima.
} 
intervalo de confiança de $95 \%$ ) da probabilidade de um partido lançar candidato quando se passa de uma situação onde há mais de 75\% de comissões provisórias em um estado para uma situação em há menos de $25 \%$, isto é, de uma estrutura centralizada para uma estrutura descentralizada, mantendo a variável Chance fixa em 0 , isto é, quando, aparentemente, não há chance de vitória .

TABELA 4.6 - PRIMEIRAS DIFERENÇAS E RAZÃO DE RISCO, COM INTERVALO DE CONFIANÇA DE 95\%, PARA A DIFERENÇA NA PROBABILIDADE DE UM PARTIDO SEM CHANCE LANÇAR CANDIDATOS QUANDO SE PASSA DE MENOS DE 25\% DE DIRETÓRIOS EM UM ESTADO PARA MAIS DE 75\%

\begin{tabular}{|c|c|c|c|}
\hline \multicolumn{4}{|c|}{ Primeiras diferenças nos valores esperados: $E(Y \mid X 1)-E(Y \mid X)$} \\
\hline Média & Desvio Padrão & $2.5 \%$ & $97.5 \%$ \\
\hline 0.3168 & 0.06355 & 0.1883 & 0.4407 \\
\hline \multicolumn{4}{|c|}{ Razão de Risco $P(Y=1 \mid X 1) / P(Y=1 \mid X)$} \\
\hline Média & Desvio Padrão & $2.5 \%$ & $97.5 \%$ \\
\hline 2.44 & 0.4250 & 1.703 & 3.335 \\
\hline \multicolumn{4}{|c|}{$\begin{array}{l}\text { Obs.: } \mathrm{E}(\mathrm{Y} \mid \mathrm{X} 1) \text { é o valor esperado da variável dependente (um partido lançar um candidato sem chan } \\
\text { quando ele possui mais de } 75 \% \text { de diretórios. } \mathrm{E}(\mathrm{Y} \mid \mathrm{X}) \text { é o valor esperado da variável dependente qua } \\
\text { ele possui menos de } 25 \% \text { de diretórios. } \mathrm{P}(\mathrm{Y}=1 \mid \mathrm{X} 1) \text { e } \mathrm{P}(\mathrm{Y} \mid \mathrm{X}) \text { são as probabilidades de que um partido } \\
\text { lance um candidato sem chances quando ele possui mais de } 75 \% \text { de diretórios e menos de } 25 \% \text { de } \\
\text { diretórios respectivamente. }\end{array}$} \\
\hline
\end{tabular}

A Tabela 4.6 mostra que quando se passa de uma situação onde um partido possui menos de $25 \%$ de comissões provisórias em um estado para uma situação em que este partido tem mais de $75 \%$ de diretórios, isto é, quando se passa de uma situação de partido altamente centralizado (pois menos diretórios significa mais comissões provisórias que, como vimos, significa maior poder para os dirigentes e, portanto, maior centralização) para uma de um partido mais descentralizado a probabilidade dele lançar um candidato, mesmo quando, aparentemente, não há chance de vitória, mais que duplica (aumenta, na média, 2,44 vezes, conforme a Razão de Risco). As primeiras diferenças nos dizem que um aumento de 50\% 
na descentralização partidária, isto é, ao se passar de $25 \%$ de diretórios para $75 \%$, acarreta um aumento médio de $32 \%$ na probabilidade de se lançar um candidato.

O gráfico 4.2 mostra o quanto o modelo que incorpora a variável Conpart é melhor que um modelo que leva em conta apenas a variável Chance.

GRÁFICO 4.2 - CURVA ROC COMPARANDO O MODELO QUE SÓ LEVA EM CONTA A VARIÁVEL CHANCE COM O MODELO QUE CONSIDERA CHANCE + CONPART

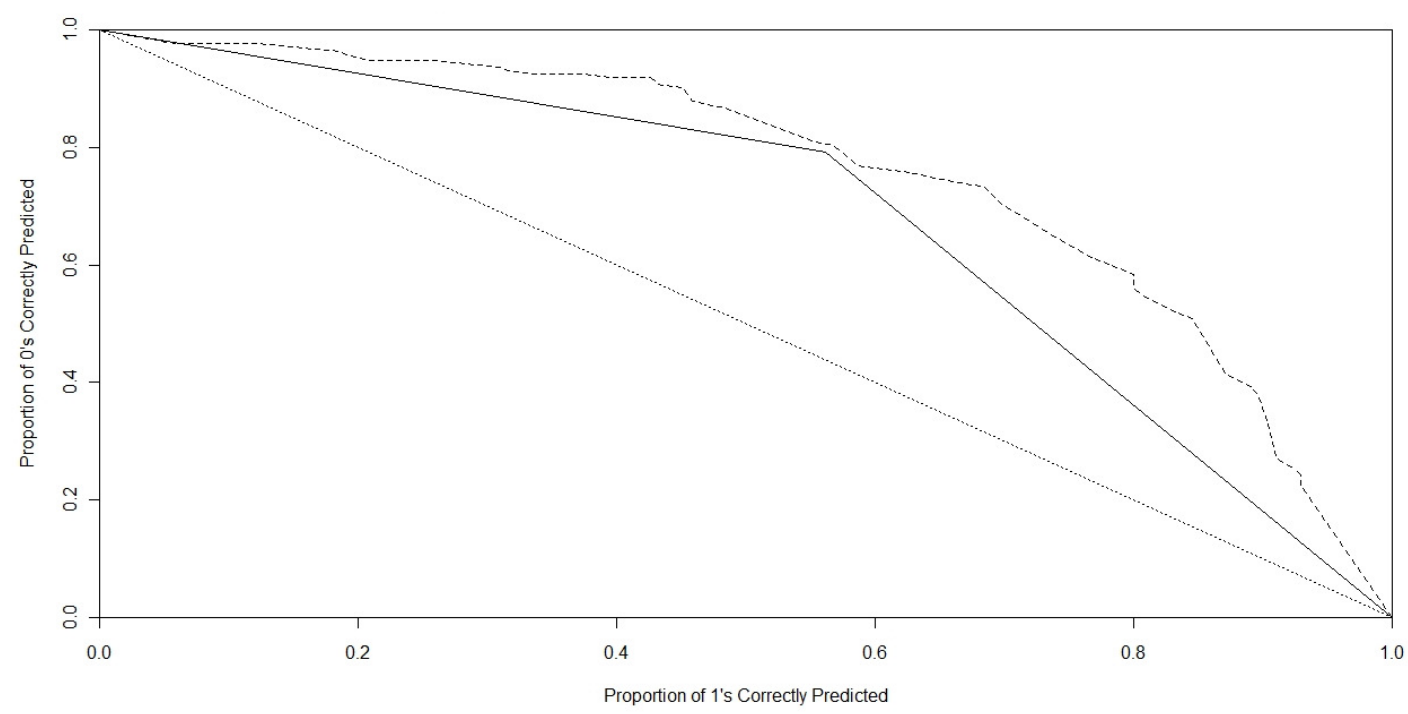

Esse gráfico mostra o quanto o modelo que relaciona a variável Entrou apenas com a variável Chance (linha sólida) e o quanto o modelo que também incorpora Conpart (linha tracejada) contribuem para explicar os 0's e 1's (a decisão de não entrar e entrar, respectivamente). Quanto mais perto do canto superior direito maior o poder explicativo de um modelo e quanto mais distante da linha diagonal pontilhada está um modelo com 
relação a outro melhor seu desempenho explicativo ${ }^{63}$. Assim vemos que o modelo que incorpora a variável Conpart ajuda a explicar mais a decisão de um partido se lançar em uma disputa do que o modelo que leva em conta apenas a variável Chance.

\section{Testando os modelos de entrada nas eleições para prefeitura}

Infelizmente não dispomos de dados sobre a posição dos partidos no nível municipal, portanto o modelo de entrada que usaremos no caso das eleições para prefeito só irá levar em conta as variáveis independentes Entrou e $C P$. A variável $C P$, substitui a variável Conpart, pois no nível municipal esta variável deixa de ser contínua e passa a ser dicotômica: ou o partido possui um diretório ou possui uma comissão provisória ${ }^{64}$. Essa variável tem valor 1 caso haja uma Comissão Provisória do partido no município ou 0 se houver diretório. A variável ENTRpref consiste em 37.888 decisões dos sete principais partidos brasileiros de lançar candidatos em eleições municipais ${ }^{65}$. Assim nosso modelo de entrada para prefeitura se resume a:

\section{ENTRpref $=\beta_{0}+\beta_{1}$ CHANCE $+\beta_{2} \mathrm{CP}+\varepsilon$}

A tabela 4.7 mostra os resultados da regressão logit:

\footnotetext{
${ }^{63}$ A linha diagonal pontilhada mostra como seria a curva ROC se as probabilidades dos 0's e 1's se dessem ao acaso não se relacionado aos dados. Ver King e Zeng, 2000.

${ }^{64}$ Casos onde não havia nenhuma estrutura consideramos missing já que um partido sem nenhuma estrutura não pode lançar candidatos no nível municipal.

${ }^{65}$ Os dados se referem a municípios dos estados do Acre, Amapá, Mato Grosso do Sul, Pernambuco, Rio de Janeiro, Rio Grande do Sul, Santa Catarina e São Paulo. Foram selecionados 2662 municípios em 2000, 2675 municípios em 2004, e 2573 municípios em 2008. Os partidos são o PDT, DEM/PFL, PMDB, PP/PPB, PSDB, PT E PTB.
} 
TABELA 4.7- - COEFICIENTES ESTIMADOS, ERROS PADRÃO, VALORES DE |Z| E SIGNIFICÂNCIA PARA O MODELO DE ENTRADA PARA AS ELEIÇÕES MUNICIPAIS.

\begin{tabular}{lrrrc} 
& Coeficiente & Erro Padrão & \multicolumn{1}{c}{$\mathrm{Z}$} & $\operatorname{Pr}(>|\mathrm{z}|)$ \\
\hline Intercepto & $-0,9035$ & 0,0216 & $-41,77$ & $<2 \mathrm{e}-16$ \\
Chance & 1,6014 & 0,0258 & 61,96 & $<2 \mathrm{e}-16$ \\
Esq & $-0,0588$ & 0,0277 & $-2,12$ & $0,034^{* *}$ \\
Conpart & $-0,7339$ & 0,0256 & $-28,72$ & $<2 \mathrm{e}-16$ \\
\hline \hline
\end{tabular}

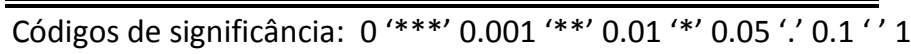

Desvio modelo nulo: 44382 on 34596 graus de liberdade

Desvio residual: 38559 on 34593 graus de liberdade

AIC: 38567

Como podemos ver as variáveis Chance e $C P$ são significativas a um nível de significância de 0,001 e a variável Esq a um nível de 0,05. A tabela 4.8 mostra as primeiras diferenças e a razão de risco de um partido lançar um candidato quando não há chance de vitória.

\begin{abstract}
TABELA 4.8 - PRIMEIRAS DIFERENÇAS E RAZÃO DE RISCO, COM INTERVALO DE CONFIANÇA DE 95\%, PARA A DIFERENÇA NA PROBABILIDADE DE UM PARTIDO SEM CHANCE LANÇAR CANDIDATOS QUANDO HÁ A PRESENÇA DE DIRETÓRIO E QUANDO HÁ COMISSÃO PROVISÓRIA.
\end{abstract}

Tabela 4.8 - Primeiras diferenças e razão de risco, com intervalo de confiança de $95 \%$, para a diferença na probabilidade de um partido sem chance lançar candidatos quando há a presença de Diretório e quando há Comissão Provisória.

\begin{tabular}{cccc}
\multicolumn{4}{c}{ Primeiras diferenças nos valores esperados: $\mathrm{E}(\mathrm{Y} \mid \mathrm{X} 1)-\mathrm{E}(\mathrm{Y} \mid \mathrm{X})$} \\
\hline Média & Desvio Padrão & $2.5 \%$ & $97.5 \%$ \\
0.1239 & 0.004268 & 0.1155 & 0.1318 \\
\hline \multicolumn{4}{c}{ Razão de Risco $\mathrm{P}(\mathrm{Y}=1 \mid \mathrm{X} 1) / \mathrm{P}(\mathrm{Y}=1 \mid \mathrm{X})$} \\
\hline Média & Desvio Padrão & $2.5 \%$ & $97.5 \%$ \\
1.773 & 0.03556 & 1.705 & 1.843 \\
\hline
\end{tabular}

Obs.: $\mathrm{E}(\mathrm{Y} \mid \mathrm{X} 1$ ) é o valor esperado da variável dependente (um partido lançar um candidato sem chances) quando ele se constitui como diretório. $\mathrm{E}(\mathrm{Y} \mid \mathrm{X})$ é o valor esperado da variável dependente quando ele se constitui como comissão provisória. $\mathrm{P}(\mathrm{Y}=1 \mid \mathrm{X} 1)$ e $\mathrm{P}(\mathrm{Y} \mid \mathrm{X})$ são as probabilidades de que um partido lance um candidato sem chances quando ele se constitui como diretório e como comissão provisória respectivamente. 
A Razão de Risco nos diz que a probabilidade de um partido lançar candidatos quando aparentemente não tem chance de vitória, é quase o dobro (1,773 vezes maior) se estiver estruturado como Diretório do que se estiver estruturado como Comissão Provisória. As primeiras diferenças nos dizem que a probabilidade de se lançar um candidato sem chance aumenta em $12,4 \%$ quando se passa de uma estrutura provisória para uma estrutura mais permanente, passando de uma média de $16 \%$ para $28 \%$..

Esses valores são mais baixos que os valores obtidos no caso das eleições para o governo do estado, mas também confirmam nossa hipótese de que partidos pouco estruturados tendem a coordenar melhor que partidos estruturados.

A figura 4.2 mostra esses resultados dentro de um intervalo de confiança de $95 \%$. 
FIGURA 4.2 - VALORES PREDITOS, VALORES ESPERADOS, PRIMEIRAS DIFERENÇAS E RAZÃO DE RISCO DA PROBABILIDADE DE SE LANÇAR CANDIDATOS A PREFEITO QUANDO NÃO SE TEM CHANCE E SE PASSA DE COMISSÃO PROVISÓRIA (X) PARA DIRETÓRIO (X1), DENTRO DE UM INTERVALO DE

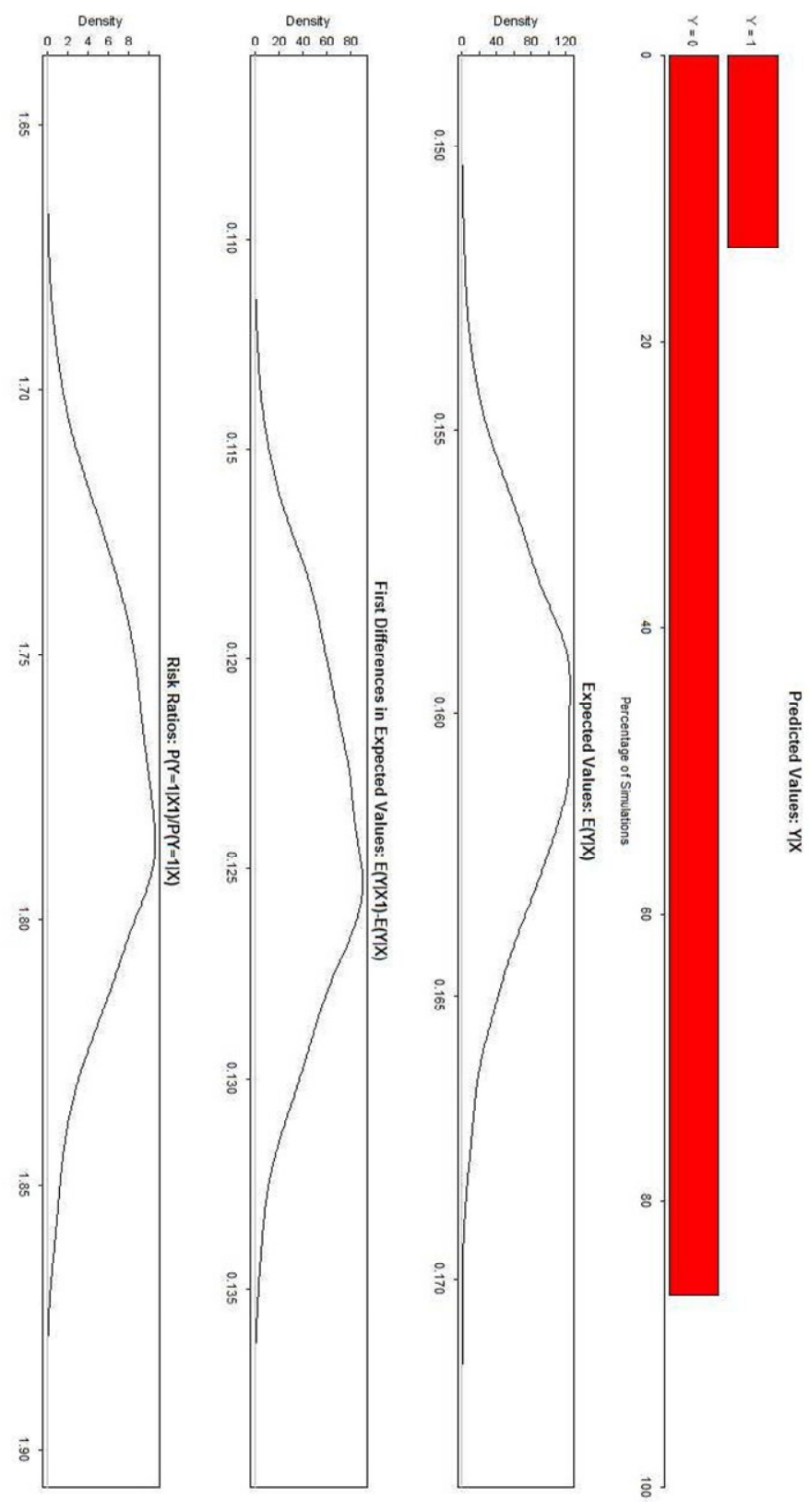

$95 \%$. 


\section{Conclusão}

Os trabalhos de Duverger (1958) e de Cox (1997) mostram que candidatos sem chance de vitória não entrariam na disputa, a não ser quando tivessem outros objetivos que não a conquista do poder. Nossos resultados mostram que a probabilidade de um partido tomar uma decisão sub-ótima é maior se o processo de tomada de decisão for descentralizado. Esses resultados estão em acordo com os estudos que mostram que os militantes são mais ideológicos do que as lideranças (TSEBELIS, 1998).

Quando o partido não tem chance de vitória e resolve entrar na disputa ele estará "tirando" os votos de um candidato próximo ideologicamente com maiores chances, podendo levar à derrota deste candidato e à vitória de um candidato mais distante. As lideranças, por serem mais moderadas, estariam mais dispostas a abrir mão de uma candidatura.

As falhas de coordenação têm impacto na representatividade do sistema partidário. Quando, em sistemas majoritários, a maioria se vê dividida porque houve falha de coordenação, a minoria pode sair vitoriosa. Portanto, conforme nossos resultados, sistemas onde os partidos são descentralizados tendem a serem menos representativos do que sistemas onde as lideranças controlam as decisões partidárias.

Vários analistas políticos consideram as coligações eleitorais como um dos grandes defeitos do sistema político brasileiro. Os projetos de reforma política sempre propõem limitações a elas. As coligações tiveram um papel central no diagnóstico da crise político-institucional 
brasileira de 1964 e hoje seria um dos fatores responsáveis pela baixa representatividade do sistema. Conforme Souza (1976):

Tomada pela maioria dos observadores como uma perversidade do sistema partidário, como um sinal de seu artificialismo e de sua congênita inorganicidade, a proliferação de alianças é também vista, numa lógica não de todo satisfatória, como sintoma de sua desagregação no embate com os processos de mudança sócio-econômica. (SOUZA, 1976:154)

Ou como nos diz Lima Júnior (1983):

Como os partidos não se mostravam capazes de manter uma imagem pública distinta e não possuíam bases de classe suficientemente nítidas, dizia-se que as alianças representavam apenas instrumentos eleitoreiros usados por líderes personalistas, sendo, portanto, tanto a conseqüência como a causa da falta de representatividade do sistema partidário. (LIMA Jr., 1983:62, grifo meu)

Nesta visão os partidos ou são meras emanações dos interesses de classe ou não têm função. A representatividade do sistema está ligada ao vínculo que os partidos teriam com suas bases de classe. Haveria, em um extremo, partidos operários, formado por operários, em outro extremo, partidos burgueses formados pela burguesia e no meio tantos partidos quanto classes que se possa discernir.

Essa visão classista, mecanicista e rígida, é revista por Soares (2001) que propõe que as coligações não refletiam nem irracionalidade e nem inexistência de estruturação no comportamento das organizações partidárias, mas precisamente o oposto. Souza concorda com Soares e diz que as coligações "revelam uma crescente racionalização daquele 
comportamento em face das normas então vigentes e de seu embasamento sócioeconômico" (citado em SOUZA, 1973:154).

A racionalidade a que Soares e Souza se referem é a racionalidade downsiana que embasou os modelos analisados neste capítulo. Assim seria racional para um partido que não possui o número de votos suficientes para se eleger, coligar com outro partido com maiores chances para, juntos, evitar a adoção de uma política que para ambos seria a pior alternativa. Como nos diz Soares "como nenhuma classe era eleitoralmente hegemônica e o sistema era multipartidário, abriu-se as portas para as coligações eleitorais" (SOARES, 2001:143).

As coligações seriam explicadas pelo "tamanho do partido" e pelo número de cadeiras em jogo, isto é, pela magnitude do distrito. Partidos pequenos, com poucas chances de voto, se coligariam mais que os grandes, com maiores chances ${ }^{66}$. Quanto menor o número de cadeiras em jogo, maior a probabilidade de coligações que, portanto, diminuem quando passamos do sistema majoritário para o proporcional e, neste, das eleições federais para as estaduais $^{67}$.

\footnotetext{
${ }^{66}$ O tamanho do partido como chance de vitória aparece em Souza (1976). Em Soares o tamanho do partido é definido a priori como os maiores partidos em termos de representação na Câmara federal, o que é criticado em Lima Júnior (1983).

${ }^{67}$ Esse modelo estaria de acordo com os modelos que vimos neste capítulo que consideram a probabilidade de vitória como variável chave para se explicar a coordenação eleitoral. No entanto, embora Souza reconheça que "o suposto de racionalidade refere-se somente às decisões tomadas pelas cúpulas partidárias" (1976:156), não há neste modelo uma variável que dê conta de variações na capacidade das cúpulas partidárias tomarem sua decisão.
} 
Assim os partidos estariam tanto maximizando suas chances de conquistar uma cadeira, no caso das eleições proporcionais, quanto minimizando as chances de que vença uma política muito distante da que ele prefere, no caso das eleições majoritárias.

No argumento de Soares os eleitores são sinceros $^{68}$ e punem aqueles partidos que se desviam do seu ponto ideal. Por isso, conforme este autor:

Um partido com base de classe diversificada e ampla pode entrar em coligações mais facilmente do que um partido com uma base de classe limitada. A ideologia dos partidos com extensa base social é mais ampla e fluida, dando pouca ênfase à classe como dimensão político-ideológica. (SOARES, 2001:170)

Assim, as alianças seriam recursos mais utilizados em eleitorados menos ideológicos, caso do "Brasil subdesenvolvido", embora pudessem ocorrer no "Brasil desenvolvido" toda vez que as questões em jogo tivessem importância.

Se considerarmos representatividade como sendo o grau com que a distribuição de opinião no legislativo reflete a distribuição de opinião dos eleitores, vemos que o fato das alianças maximizarem a chance de um partido conseguir uma cadeira aumenta a representatividade do sistema, já que quanto mais partidos tiverem assento em uma legislatura mais segmentos estarão representados.

Por outro lado, uma coligação eleitoral leva a compromissos entre os partidos que pode distanciá-los de suas bases, toda vez que forem feitas alianças com partidos distantes

\footnotetext{
${ }^{68}$ Soares é claro neste ponto ao afirmar que a racionalidade eleitoral "não pressupõe a racionalidade das massas e das classes" (SOARES, 2001:144)
} 
ideologicamente. Como o compromisso é feito pela cúpula que, muitas vezes, fariaprevalecer seus interesses pessoais em detrimento dos interesses das bases sociais, este compromisso levaria a uma menor representatividade.

Soares mostra dados que apontam para o lado positivo das coligações. Mostra, citando os estudos de Isabel Ribeiro de Oliveira que, por sua vez, questionam os resultados apresentados por Wanderley Guilherme dos Santos, que as coligações “inconsistentes" não são muitas. Citando Figueiredo e Limongi (1995) mostra que isso também é verdade para a arena parlamentar.

Podemos dizer que quando consideramos o comportamento político como racional, no sentido downsiano, as alianças passam a ter um papel positivo na representatividade do sistema político por aumentar as chances de partidos que estariam sub-representados devido às restrições do sistema eleitoral. Cox (1997) irá qualificar melhor este ponto.

Cox defende que, mais que a representatividade do ponto de vista da correspondência entre a opinião do eleitorado e a opinião dos formuladores de políticas, deve-se levar em conta se a política adotada pelo governo se encontra o mais próximo possível da opinião da maioria da população, o que significa que deve ser mais próxima o possível do eleitor mediano. Enquanto no primeiro caso a representatividade exige que a arena decisória seja um espelho, no segundo caso ela deve ser centrista.

Seguindo o modelo espacial de Hotteling e Downs, Cox mostra como a posição que os partidos adotam em uma dimensão da competição eleitoral depende da magnitude do distrito. Haveriam duas condições para que a localização dos partidos estivessem em equilíbrio, a condição do range mínimo e a condição do gap interior. 
A condição do range mínimo nos diz que há um limite inferior e superior para a posição dos partidos nos pontos $1 /(\mathrm{M}+1)$ e $\mathrm{M} /(\mathrm{M}+1)$, isto é, os partidos devem se localizar no ponto em que menos de $1 /(\mathrm{M}+1) \%$ e mais de $\mathrm{M} /(\mathrm{M}+1) \%$ dos eleitores se localizam. Quanto maior a magnitude do distrito maior este limite, assim em uma disputa por apenas uma vaga os limites inferior e superior seriam o mesmo $=1 / 2$, ou seja, o mediano. Já numa disputa por oito cadeiras o limite inferior seria $1 / 9$ e o superior 8/9.

Por outro lado, como vimos quando analisamos o modelo de entrada de Palfrey, uma distância (gap) muito grande entre os partidos pode permitir a entrada de um terceiro que consegue a vitória por capturar uma maioria de votos centristas. Assim a condição do gap interior restringe a distância entre os competidores para menos de 1/(M+1). Quanto maior a magnitude do distrito menor deve ser o gap.

Tanto a condição do range mínimo quanto a condição do gap interior mostram que a representatividade, enquanto espelho da opinião dos eleitores, aumenta com o aumento da magnitude do distrito. No entanto, se considerarmos a proximidade da política efetivamente adotada pelo governo com relação à opinião do "mediano global" uma menor magnitude levaria a uma melhor representatividade do sistema.

Mas essa melhor representatividade "global" dos sistemas eleitorais fortes não é automática. Uma crítica ao sistema majoritário de um turno é que quando há acúmulo de partidos no centro eles acabam dividindo esses votos e possibilitam a vitória de um candidato extremo. Para que isso não ocorra é essencial que haja coordenação tanto por meio do voto estratégico, quanto por meio da coordenação pré-eleitoral. Quando há 
coordenação eleitoral sistemas majoritários levam a políticas mais centristas e, portanto, a uma maior representatividade.

Deste modo, vemos que ao adotarmos o princípio da racionalidade do comportamento político somos levados a concluir que a coordenação eleitoral leva a uma maior representatividade do sistema, quer consideremos essa representatividade como a semelhança entre a distribuição das opiniões na arena decisória e a distribuição da opinião no eleitorado, como vimos em Soares, quer consideremos representatividade como a distância entre a política adotada por um governo e a política preferida pelo eleitor mediano, como em Cox.

Concluindo e retomando a discussão iniciada no Capítulo1, podemos afirmar que uma parte da resposta à questão do porquê mesmo com presidencialismo e multipartidarismo conseguimos ter uma democracia estável por 25 anos passa pela centralização das decisões no interior dos partidos.

No próximo capítulo veremos como se deu a relação entre organização partidária e competição eleitoral em casos concretos envolvendo os sete partidos analisados aqui e agrupados conforme a o tipo de organização. 


\section{CAPÍTULO 5 - MODELOS ORGANIZATIVOS}

Neste capítulo iremos mostrar, por meio da análise da história organizacional dos partidos, como a organização partidária se articulou com a arena eleitoral em casos concretos. Iremos retomar a tipologia desenvolvida no Capítulo 2 para mostrar como diferentes graus de centralização partidária correspondem a diferentes estratégias eleitorais. Nossa intenção aqui é não só dar mais concretude à análise feita até então, como também ressaltar o caráter dinâmico do modelo, mostrando que os partidos são dominados por conflitos e que esses conflitos ajudam a moldar a fisionomia desses partidos.

\section{Partidos Poliárquicos}

Os três partidos considerados como poliárquicos/organizados ocupam posições diferentes no espectro ideológico, o PT está à esquerda e o PMDB e o PSDB ocupam o centro. Apesar desta diferença tanto o PT quanto o PMDB enfrentam ou enfrentaram graves divisões internas que levaram alguns analistas a classificá-los como partidos de tendências e de facções (AZEVEDO, 1995, MARQUES e FLEISCHER, 1999). O PSDB se originou de uma cisão do PMDB e se organizou rapidamente graças aos diretórios herdados do PMDB. Do mesmo modo o PSOL e o PSTU, dois pequenos partidos que não serão analisados, eram facções que romperam com o PT.

Acreditamos que essas divisões são conseqüência direta do processo de desenvolvimento organizacional destes partidos. O fato de eles estarem estruturados com órgãos permanentes, eleitos pela base, faz com que seus dirigentes locais e regionais tenham certa independência da direção nacional e, por isso, maior força nas disputas partidárias. 
Mas, apesar das semelhanças entre os três partidos quanto ao grau de desenvolvimento e às divisões internas, o modo como eles lidam com essas divisões são bastante diversos. Enquanto no PMDB as divisões paralisam o processo de tomadas de decisão, geram menos disciplina partidária e tornam o partido incapaz de se apresentar unido na arena eleitoral nacional, no PT impera o "centralismo democrático" onde o debate é estimulado e aceito, mas onde as decisões são tomadas pela cúpula em caráter definitivo e aceitas por todos. No PSDB, menos dividido, as decisões são tomadas pela cúpula que quase sempre evita, por meio de acordos, que as divisões internas se transformem em disputas institucionais.

Essas diferenças correspondem às muitas formas que, segundo Panebianco, as poliarquias partidárias podem assumir. Conforme este autor:

\footnotetext{
"No meu entendimento é necessário distinguir entre uma poliarquia composta por subcoalizões e uma poliarquia composta por facções nacionais. No primeiro caso a poliarquia também poderá aparecer, à primeira vista, uma monocracia: de fato geralmente a coalizão é formada por um líder 'central' de grande prestígio e, portanto, mais 'visível' e pelos líderes (periféricos) das subcoalizões... No segundo caso a coalizão será uma aliança de várias facções e muitos líderes (os chefes das facções) estarão em primeiro plano." (PANEBIANCO 2005, pg. 332)
}

Esse trecho de Panebianco se ajusta perfeitamente aos casos do PT e do PMDB. No PT há um líder central de enorme prestígio, Lula, e no PMDB há uma multiplicidade de líderes regionais que sempre estão em primeiro plano (José Sarney, Orestes Quércia, Jarbas Vasconcelos, Pedro Simon, Roberto Requião, Jáder Barbalho, etc.). 
O porquê destas diferenças pode ser mais bem compreendido se analisarmos o modo como esses partidos se constituíram em seu momento originário e o modo como foram resolvidas algumas disputas críticas durante sua história. É o que faremos a seguir.

\section{Partido dos Trabalhadores - PT}

O Partido dos Trabalhadores é formado por grupos que, com o processo de abertura iniciado no final dos anos 70, mais especificamente com a nova Lei dos Partidos de 1979, procuravam se inserir no "mercado político". Esses grupos compreendiam parte do operariado ligado ao parque industrial mais moderno, movimentos sociais organizados pela Igreja Católica, setores da intelectualidade (MENEGUELLO, 1989).

Os membros oriundos do sindicalismo tiveram, desde o início, uma grande força no interior do partido. O fato das principais lideranças sindicais da época serem paulistas fez com que a organização do partido em âmbito nacional se confundisse com a organização do partido no estado. Não é por acaso que, até 2008, o Diretório Nacional do partido funcionasse no centro da capital paulista.

Durante a primeira década de vida os sindicalistas, agrupados na "tendência" 69 Articulação, constituíram a principal força do PT. A Articulação agrupava membros

\footnotetext{
${ }^{69}$ Segundo a resolução sobre "Tendências" de 1987:

O PT não confunde tendências internas de opinião com partidos dentro do partido, assegurando, pois, a qualquer grupo de militantes o direito de constituir-se como tendência interna do partido.

a) Uma tendência do PT é um grupo de petistas que se agrupa, ou se organiza, para defender posições no interior do partido, a partir de uma base política (podendo adotar o nome de tendência, corrente, agrupamento...).

b) As tendências do PT se distinguem das articulações ou blocos de militantes que se formam apenas nos períodos de encontros.

c) As tendências do PT deverão respeitar escrupulosamente seu caráter de agrupamento de militantes para defender posições no interior do partido. Submetido à disciplina partidária como militante, nenhum
} 
oriundos do sindicalismo e parte de membros oriundos de agrupamentos clandestinos de esquerda com amplo apoio entre universitários. O Quadro 5.1 mostra a divisão do PT nesta primeira década e a posição das principais forças:

QUADRO 5.1 - OS BLOCOS PARTIDÁRIOS DO PT EM 1991

\begin{tabular}{|l|l|l|l|}
\hline Tendência Majoritária & Tendências Minoritárias & Vertente socialista \\
\hline Articulação & Fova Esquerda & $\begin{array}{l}\text { Democracia } \\
\text { Socialista }\end{array}$ & PT Vivo \\
& $\begin{array}{l}\text { Partido } \\
\text { Revolucionário } \\
\text { Operário }\end{array}$ & $\begin{array}{l}\text { Convergência } \\
\text { Socialista }\end{array}$ & \\
& $\begin{array}{l}\text { Partido Comunista } \\
\text { Brasileiro } \\
\text { Revolucionário }\end{array}$ & $\begin{array}{l}\text { Luta pelo } \\
\text { Socialismo }\end{array}$ & \\
& Ala Vermelha & Partido Operário & \\
& Revolucionário & \\
& Movimento por & Lute de Classes & \\
uma tendência & Causa Operária & \\
& Marxista & & \\
\hline
\end{tabular}

FONTE: AZEVEDO (1995)

O predomínio da Articulação pode ser explicado, e parte, pela estratégia de construção do partido que adotou um tipo de desenvolvimento por difusão baseado na rede dos sindicatos locais e das comunidades eclesiais de base. Esta estratégia além de levar ao domínio dos

agrupamento interno ou tendência poderá expressar-se nessa condição diretamente à sociedade, seja através de manifestações públicas, seja através da imprensa ou por qualquer outro meio. Por conseguinte, os instrumentos de veiculação de suas políticas devem dirigir-se exclusivamente aos membros do partido. d) As coordenações das tendências, bem como suas políticas, devem ser transparentes para o conjunto do partido.

e) O caráter apenas interno das tendências não admite que suas necessidades financeiras para articular ou divulgar suas posições políticas sejam supridas por atividades externas ao partido. Por conseguinte, suas finanças só podem ser obtidas no interior do partido, sem concorrer ou prejudicar as atividades de finanças do PT, razão pela qual devem estar submetidas à política de finanças do partido.

f) Uma tendência do partido não pode constituir um partido distinto do PT, nem usar nome de partido. Deve reconhecer expressa e praticamente o PT como um partido estratégico (rumo ao socialismo). 
sindicalistas ${ }^{70}$ também fez com que a organização do partido se desse de forma muito rápida. Em menos de um ano o PT conseguiu organizar comissões municipais em 627 cidades conquistando 300 mil filiados (MENEGUELLO, 1989).

A constituição de diretórios baseados na estrutura sindical existente fez com que os sindicalistas transferissem para o partido a relação de força existente no meio sindical, isto é, do mesmo modo com que controlavam os sindicatos locais estes dirigentes passaram a dominar vários diretórios locais do partido.

Essa situação durou até começos da década de 1990 quando o partido, já havendo conquistado o poder em grandes cidades, fragmenta-se ainda mais conforme Quadro 5.2.

QUADRO 5.2 - OS BLOCOS PARTIDÁRIOS DO PT EM 1995

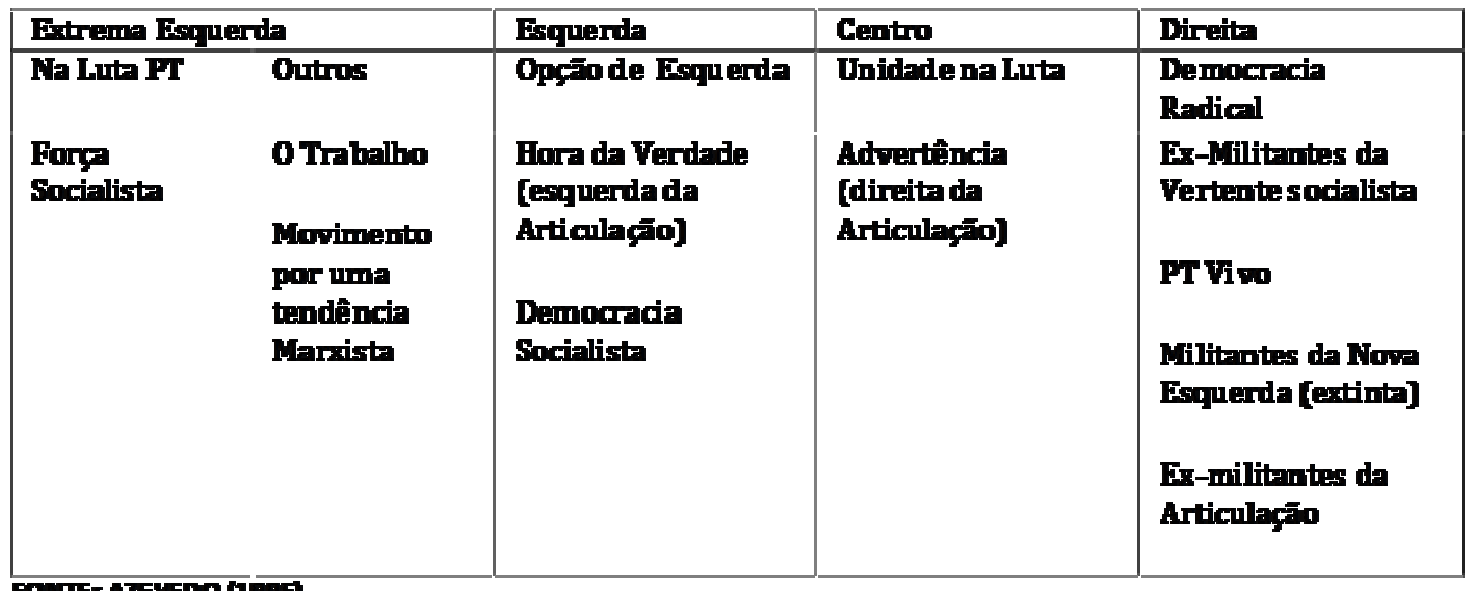

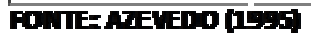

\footnotetext{
${ }^{70}$ Nos referimos aqui ao que Azevedo chama de "sindicalistas autênticos", isto é, aqueles que detinham cargos de direção nos sindicatos oficiais no começo da década de 80. Outras correntes do sindicalismo se juntaram ao PT e nem todas se agruparam na Articulação.
} 
Este quadro mostra que entre 1991 e 1995 a tendência Articulação se divide e a partir deste momento a construção de maiorias se torna problemática, conforme esta passagem de Azevedo (1995):

Em um primeiro momento juntaram-se as forças de 'esquerda' e de 'extrema esquerda' para derrotar o 'centro' e 'direita' que atuavam separados. Depois aliaram-se a 'esquerda' e o 'centro', com o apoio da 'direita', para derrotar a 'extrema-esquerda'. Mais tarde voltaram a confrontar-se de um lado a 'esquerda' e a 'extrema esquerda' e, de outro, o 'centro' e a 'direita', agora aliados. Em seguida juntaram-se o 'centro' e a maioria da 'esquerda', nessa hora dividida, agradando parcialmente à 'direita' e desagradando por inteiro a 'extrema-esquerda'...

(AZEVEDO, 1995 pg. 156)

Essa citação parece ilustrar de maneira exemplar o conhecido paradoxo do voto segundo o qual, mesmo quando indivíduos possuem preferências estritamente transitivas, a preferência coletiva pode ser intransitiva levando a ciclos onde as maiorias que se formam são efêmeras. No período entre 1991 e 2000 não havia o que os teóricos da escolha racional chamam de Condorcet winner. Aproximando-se do mundo instável e imprevisível do teorema de Arrows, maiorias ad hoc se formavam apenas para frustar as pretensões da maioria formada antes.

Esse período de instabilidade começa com o primeiro golpe na Articulação: a derrota de Lula na corrida pela Presidência da República de 1989. A força do carisma de Lula também explica a permanência da Articulação no controle do partido e sua derrota abre o flanco para os adversários internos. É um momento de autocrítica do partido e também um 
momento no qual correntes até então minoritárias passam a aspirar ao controle partidário. Isso se reflete em uma resolução de maio de 1990 que propõe:

A democracia interna do PT é um dos valores de que os petistas mais se orgulham. Característica do Partido desde as suas origens, a democracia interna é virtude diferenciada entre o PT e os demais partidos, tanto os burgueses quanto os partidos convencionais de esquerda. Neste sentido, é preciso incluir no Regimento Interno a composição proporcional em todas as instâncias de direção, com representação de todas as chapas que alcancem $10 \%$ de votação nos

Encontros. Essa medida tem o sentido de consolidar nossa tradição pluralista e impulsionar a construção da unidade partidária (PT, 1990, grifo meu)

Nesta época o partido havia crescido, contando com um grande número de prefeitos e uma bancada expressiva. Esses novos líderes vinham de regiões onde não havia o predomínio dos sindicalistas e representaram a ascensão de novos grupos, como a tendência Partido Comunista Brasileiro Revolucionário que conquistou a prefeitura de Fortaleza com Maria Luisa Fontenelle.

O $1^{\circ}$ Congresso do partido, de 1991, resolve abrir ainda mais o processo de escolha de dirigentes ampliando a participação de núcleos de base e de instâncias locais e regionais. Com esse incentivo a candidaturas, mesmo que avulsas, surgem miríades de postulantes à direção nacional. Mesmo a Articulação, com o sucesso eleitoral de alguns de seus membros, acabou rachando e, em 1994, Rui Falcão assume a presidência com o afastamento de Lula para concorrer à Presidência da República, apesar da preferência de Lula por José Dirceu. Em 1995, graças à intervenção direta de Lula, que deixava a 
presidência após 13 anos de mandato interrompido apenas pelos períodos de disputa eleitoral, José Dirceu assume o controle do partido ${ }^{71}$.

As disputas no interior do PT tinham como pano de fundo a estratégia eleitoral partidária. Grupos de "direita" e de "centro", diante das derrotas de 1989 e 1994, pregavam uma ampliação do leque de alianças, o que só seria possível com uma maior moderação no discurso. As correntes mais à esquerda achavam que o problema estava justamente na adoção de um discurso mais moderado e que o partido só chegaria ao poder adotando posturas mais radicais. José Dirceu é reeleito em 1997 com a tese de que a arco de alianças do partido deveria ser ampliado. No entanto sua vitória é apertada: 284 votos, contra 256 de seu adversário, o deputado federal Milton Temer. Com a vitória do grupo moderado foi aprovada a "Carta do Rio de Janeiro", que declarava a posição do PT sobre alianças eleitorais. O documento contemplava a participação, no palanque da legenda, dos partidos de esquerda até "todos os segmentos sociais e políticos que se opõem ao projeto neoliberal

\footnotetext{
${ }^{71}$ Um documento do Encontro que elegeu a nova direção partidária dá uma idéia do nível de conflito interno e das dificuldades que esse conflito gerava:

"UM NOVO MÉTODO DE DIREÇÃO

1- Na perspectiva de superar as dificuldades hoje vividas pelo Partido, não se deve transformar a avaliação do último período num ajuste de contas revanchista. Apontar os limites e erros cuja evidência, de resto, dispensam comentários, deve constituir-se em um gesto construtivo, visando sua superação. Embora a responsabilidade maior pelos erros e acertos de direção caiba à atual maioria, as minorias não podem deixar de assumir sua parte.

(...)

3- A nova direção, marcada pela falta de um projeto coerente e pela carência de solidariedade interna, foi incapaz de elaborar e viabilizar políticas que permitissem ao Partido superar os seus impasses organizativos e políticos. A situação, que em 93 já era preocupante, agravou-se.

(...)

9- O modo como hoje se constrói a direção é federativo e freqüentemente irracional. Ele soma a representação das tendências internas, mas não expressa a inserção social do PT, nem corresponde, como deveria, às tarefas concretas que a direção terá que desempenhar. "Ou seja, as regras estabelecidas para assegurar a democracia - que é fundamental e deve ser preservada - não garantem uma direção à altura da necessidade." (PT, 1995).
} 
e ao governo FHC". O texto estabelecia, ainda, que "nenhum interesse regional deverá prevalecer diante do desafio de barrar a recondução de FHC e bater o neoliberalismo".

Data desta época um dos mais notórios conflitos da história do partido, quando houve a intervenção no diretório estadual do Rio de Janeiro, cuja decisão de lançar Vladimir Palmeira como candidato ao governo do estado nas eleições de 1998 contrariava a estratégia do partido de se aliar com o PDT para disputar a presidência da república. Em troca do apoio a Lula, candidato do PT à presidência, o PDT exigia o apoio petista a Anthony Garotinho, candidato do PDT ao governo carioca. Com a intervenção a candidatura de Palmeira foi anulada e o PT passou a integrar a chapa Pedetista ocupando a vaga de vice-governador. Esse episódio mostra a força do centralismo democrático.

José Dirceu volta a ser eleito presidente do partido em 1999, desta vez concorrendo com outros dois candidatos, Milton Temer, pela esquerda, e Arlindo Chinaglia, pelo centro. Dirceu recebeu 496 dos 914 votos, Temer obteve 296 e Chinaglia 113. A composição do Diretório Nacional ficou nas mãos dos moderados de Dirceu que passaram a comandar, sozinhos, cerca de $55 \%$ das cadeiras.

Essa predominância do grupo moderado permitiu que em 2001, às vésperas das eleições para a presidência da república, fosse elaborado um novo estatuto mudan as regras de escolha de dirigentes passando a vigorar o Processo de Eleições Diretas onde os dirigentes são escolhidos por voto direto dos filiados. Desde então, não sem disputa, os moderados, originalmente o grupo dos sindicalistas, agora sob a denominação de Campo Majoritário, mantém-se no poder. 
A Tabela 5.1 mostra o porquê deste domínio. A maior parte dos filiados se concentra em São Paulo (25,3\% do total) berço do PT e lar dos principais líderes sindicais.

\begin{tabular}{|c|c|c|}
\hline & Filiados & $\%$ \\
\hline AC & 7.074 & 0,6 \\
\hline AL & 6.453 & 0,6 \\
\hline AM & 9.880 & 0,9 \\
\hline AP & 6.096 & 0,5 \\
\hline BA & 55.118 & 4,8 \\
\hline $\mathrm{CE}$ & 42.749 & 3,7 \\
\hline DF & 8.233 & 0,7 \\
\hline ES & 18.031 & 1,6 \\
\hline GO & 37.378 & 3,2 \\
\hline MA & 16.699 & 1,4 \\
\hline MG & 133.951 & 11,6 \\
\hline MS & 32.134 & 2,8 \\
\hline MT & 15.531 & 1,3 \\
\hline PA & 35.072 & 3,0 \\
\hline PB & 23.609 & 2,0 \\
\hline PE & 39.865 & 3,4 \\
\hline PI & 18.797 & 1,6 \\
\hline PR & 65.299 & 5,6 \\
\hline RJ & 85.726 & 7,4 \\
\hline RN & 9.845 & 0,9 \\
\hline RO & 11.543 & 1,0 \\
\hline $\mathrm{RR}$ & 809 & 0,1 \\
\hline RS & 114.113 & 9,9 \\
\hline SC & 45.026 & 3,9 \\
\hline SE & 14.334 & 1,2 \\
\hline SP & 292.846 & 25,3 \\
\hline TO & 10.023 & 0,9 \\
\hline Total & 1.156 .234 & 100,0 \\
\hline
\end{tabular}

FONTE: TSE

O recrudescimento do controle do grupo moderado levou também a uma mudança de perspectiva com relação ás alianças. Conforme o documento "Um outro Brasil é possível" 
elaborado no XII Encontro Nacional do partido que levou José Dirceu pela quarta vez à presidência:

A constituição de uma base eleitoral mais ampla ainda no primeiro turno dependerá de nossa capacidade de atrair nacionalmente todos os partidos (ou segmentos deles) capazes de defender um programa democrático-popular e de estabelecer alianças regionais sólidas para bater as forças de direita. Ao mesmo tempo, e junto com essa mobilização de partidos e segmentos de partidos, é fundamental realizar uma ampla mobilização social no país capaz de dar respaldo a um programa alternativo ao das forças que atualmente governam o Brasil. Isso exige flexibilidade, abandono de práticas sectárias e, sobretudo, vocação hegemônica.

Essa maior flexibilidade facilitou o processo de alianças estabelecidas nas eleições de 2002 que acabou por levar Lula e o PT à presidência. Esse maior controle sobre o partido e os conflitos que se seguiram à ascensão do PT ao governo federal também levou a uma cisão à esquerda do partido culminando com a saída de políticos que viriam a fundar o PSOL.

A história do PT mostra claramente a dificuldade do partido em participar de coligações eleitorais quando a coalizão dirigente se encontra dividida. Apenas quando a corrente moderada consegue maioria e muda as regras do jogo para consolidar este poder é que o partido consegue ampliar seu leque de alianças.

\section{Partido do Movimento Democrático Brasileiro - PMDB}


O PMDB nasceu em 1979 do antigo MDB mantendo quase integralmente seus membros (KINZO, 1989). Já o MDB havia nascido em 1966, fruto do AI2 que instaurou o bipartidarismo e fez com que os partidos existentes se fundissem, uns criando a ARENA, de situação, e outros o MDB, oposição ao regime. Essa característica fez com que, na sua origem, o partido herdasse as estruturas partidárias existentes e sofresse com várias divisões e disputas internas.

A primeira divisão interna se deu entre radicais e moderados, depois entre autênticos e não autênticos. Em 1979, alguns parlamentares saíram do MDB para fundar outros partidos como o PT, PTB, PDT e $\mathrm{PP}^{72}$, mas a maioria permaneceu na sigla agora renomeada para PMDB. Mais tarde o PP se une ao partido fazendo surgir uma disputa pelo seu controle entre Tancredo Neves (ex-PP) e Ulysses Guimarães.

As regras de escolha de dirigentes no PMDB favorecem o nível regional já que o número de delegados à convenção nacional é proporcional ao número de votos da legenda para a câmara dos deputados ${ }^{73}$, além do fato dos parlamentares terem assento garantido na convenção. Isto fez com que as decisões, no nível federal, fossem tomadas por meio de

\footnotetext{
${ }^{72}$ Trata-se do antigo Partido Popular comandado por Petrônio Portela e Tancredo Neves e não o atual Partido Progressista.

${ }^{73}$ Conforme o estatuto do partido:

“Art. 65. A Convenção Nacional será constituída:

I - dos membros do Diretório Nacional;

II - dos Delegados dos Estados e do Distrito Federal;

III - dos representantes do Partido no Congresso Nacional;

IV - dos membros do Conselho Nacional que não integrarem o Diretório Nacional.

§ 1으 - O número de Delegados que cada Estado e o Distrito Federal elegerão será de, no mínimo, 1 (um) por Unidade Federativa, e mais 1 (um) para cada 40.000 (quarenta mil) votos de legenda partidária obtidos na última eleição para a Câmara dos Deputados, desprezando o resto da divisão.

$\S 2$ - Nas Unidades da Federação onde o Partido eleger representantes na Câmara Federal, esse número será acrescido do dobro do número de Deputados eleitos pela legenda.

§ “3ㅇ- O somatório dos critérios estabelecidos nos parágrafos anteriores não poderá exceder o limite máximo de 60 (sessenta) Delegados por Unidade Federativa”.
} 
alianças políticas instáveis entre os delegados da convenção nacional. A Tabela 5.1 simula a composição dos delegados regionais por meio da aplicação das regras do estatuto. Vê-se o equilíbrio de forças no interior do partido com a exceção dos anos de 1990 e 1994 quando os diretórios de São Paulo e Minas Gerais detinham, juntos, cerca de um quarto dos convencionais. Com o tempo a força dos estados se equilibrou e o processo de tomada de decisões começou a ficar prejudicado. 
TABELA 5.2 - EVOLUÇÃO DO NÚMERO DE DELEGADOS À CONVENÇÃO NACIONAL DO PMDB POR ESTADO (1982- 2006)

\begin{tabular}{|c|c|c|c|c|c|c|c|c|c|c|c|c|c|c|}
\hline & 1982 & $\%$ & 1986 & $\%$ & 1990 & $\%$ & 1994 & $\%$ & 1998 & $\%$ & 2002 & $\%$ & 2006 & $\%$ \\
\hline Rondônia & 9 & $1,3 \%$ & 15 & $1,8 \%$ & 1 & $0,2 \%$ & 3 & $0,8 \%$ & 5 & $1,2 \%$ & 9 & $1,9 \%$ & 9 & $1,6 \%$ \\
\hline Acre & 10 & $1,5 \%$ & 12 & $1,5 \%$ & 12 & $2,8 \%$ & 10 & $2,3 \%$ & 4 & $0,8 \%$ & 4 & $0,8 \%$ & 4 & $0,7 \%$ \\
\hline Amazonas & 14 & $2,0 \%$ & 11 & $1,3 \%$ & 7 & $1,6 \%$ & 11 & $2,5 \%$ & 1 & $0,3 \%$ & 1 & $0,3 \%$ & 8 & $1,6 \%$ \\
\hline Roraima & 1 & $0,2 \%$ & 1 & $0,1 \%$ & 3 & $0,7 \%$ & 1 & $0,2 \%$ & 3 & $0,8 \%$ & 1 & $0,2 \%$ & 3 & $0,6 \%$ \\
\hline Pará & 28 & $4,2 \%$ & 42 & $5,1 \%$ & 21 & $4,9 \%$ & 25 & $5,6 \%$ & 18 & $4,1 \%$ & 30 & $6,4 \%$ & 36 & $6,5 \%$ \\
\hline Amapá & 1 & $0,2 \%$ & 4 & $0,4 \%$ & 1 & $0,3 \%$ & 1 & $0,3 \%$ & 4 & $0,8 \%$ & 1 & $0,3 \%$ & 7 & $1,2 \%$ \\
\hline Tocantins & & $0,0 \%$ & & $0,0 \%$ & 6 & $1,4 \%$ & 7 & $1,6 \%$ & 7 & $1,6 \%$ & 5 & $1,1 \%$ & 10 & $1,8 \%$ \\
\hline Maranhão & 11 & $1,7 \%$ & 25 & $3,0 \%$ & 5 & $1,1 \%$ & 17 & $3,9 \%$ & 12 & $2,7 \%$ & 14 & $2,9 \%$ & 16 & $3,0 \%$ \\
\hline Piauí & 13 & $2,0 \%$ & 10 & $1,3 \%$ & 8 & $1,8 \%$ & 8 & $1,9 \%$ & 14 & $3,1 \%$ & 12 & $2,6 \%$ & 12 & $2,2 \%$ \\
\hline Ceará & 22 & $3,3 \%$ & 48 & $6,0 \%$ & 17 & $4,0 \%$ & 22 & $4,9 \%$ & 27 & $6,0 \%$ & 28 & $6,1 \%$ & 36 & $6,6 \%$ \\
\hline R. G. do Norte & 13 & $2,0 \%$ & 18 & $2,2 \%$ & 12 & $2,7 \%$ & 9 & $2,0 \%$ & 19 & $4,2 \%$ & 17 & $3,7 \%$ & 9 & $1,7 \%$ \\
\hline Paraíba & 19 & $2,9 \%$ & 26 & $3,3 \%$ & 15 & $3,5 \%$ & 27 & $6,1 \%$ & 23 & $5,2 \%$ & 14 & $3,0 \%$ & 20 & $3,6 \%$ \\
\hline Pernambuco & 44 & $6,6 \%$ & 49 & $6,1 \%$ & 14 & $3,2 \%$ & 2 & $0,5 \%$ & 18 & $4,1 \%$ & 23 & $5,0 \%$ & 17 & $3,2 \%$ \\
\hline Alagoas & 12 & $1,7 \%$ & 15 & $1,8 \%$ & 1 & $0,3 \%$ & 5 & $1,2 \%$ & 6 & $1,4 \%$ & 6 & $1,3 \%$ & 14 & $2,5 \%$ \\
\hline Sergipe & 7 & $1,0 \%$ & 11 & $1,4 \%$ & 2 & $0,5 \%$ & 7 & $1,7 \%$ & 8 & $1,7 \%$ & 4 & $1,0 \%$ & 2 & $0,4 \%$ \\
\hline Bahia & 52 & $7,8 \%$ & 60 & $7,4 \%$ & 29 & $6,8 \%$ & 23 & $5,2 \%$ & 15 & $3,5 \%$ & 20 & $4,2 \%$ & 12 & $2,3 \%$ \\
\hline Minas Gerais & 60 & $9,0 \%$ & 60 & $7,4 \%$ & 53 & $12,5 \%$ & 47 & $10,6 \%$ & 49 & $11,0 \%$ & 42 & $8,9 \%$ & 45 & $8,2 \%$ \\
\hline Espírito Santo & 21 & $3,2 \%$ & 27 & $3,4 \%$ & 17 & $4,1 \%$ & 13 & $2,8 \%$ & 10 & $2,2 \%$ & 9 & $1,8 \%$ & 21 & $3,9 \%$ \\
\hline Rio de Janeiro & 47 & $7,1 \%$ & 60 & $7,4 \%$ & 13 & $3,0 \%$ & 18 & $4,1 \%$ & 13 & $2,8 \%$ & 32 & $6,8 \%$ & 58 & $10,6 \%$ \\
\hline São Paulo & 60 & $9,0 \%$ & 60 & $7,4 \%$ & 60 & $14,1 \%$ & 60 & $13,4 \%$ & 42 & $9,4 \%$ & 39 & $8,3 \%$ & 27 & $4,9 \%$ \\
\hline Paraná & 60 & $9,0 \%$ & 60 & $7,4 \%$ & 27 & $6,2 \%$ & 20 & $4,4 \%$ & 21 & $4,8 \%$ & 38 & $8,1 \%$ & 48 & $8,8 \%$ \\
\hline Santa Catarina & 37 & $5,5 \%$ & 40 & $4,9 \%$ & 20 & $4,8 \%$ & 24 & $5,3 \%$ & 23 & $5,2 \%$ & 27 & $5,9 \%$ & 32 & $5,9 \%$ \\
\hline R. G. do Sul & 54 & $8,1 \%$ & 60 & $7,4 \%$ & 41 & $9,6 \%$ & 39 & $8,6 \%$ & 42 & $9,4 \%$ & 35 & $7,5 \%$ & 36 & $6,6 \%$ \\
\hline M. G. do Sul & 15 & $2,3 \%$ & 15 & $1,9 \%$ & 4 & $1,0 \%$ & 12 & $2,7 \%$ & 8 & $1,8 \%$ & 12 & $2,6 \%$ & 13 & $2,4 \%$ \\
\hline Mato Grosso & 13 & $2,0 \%$ & 18 & $2,3 \%$ & 3 & $0,6 \%$ & 5 & $1,1 \%$ & 8 & $1,8 \%$ & 8 & $1,6 \%$ & 7 & $1,2 \%$ \\
\hline Goiás & 45 & $6,7 \%$ & 49 & $6,0 \%$ & 34 & $7,9 \%$ & 27 & $6,0 \%$ & 38 & $8,6 \%$ & 23 & $4,9 \%$ & 30 & $5,5 \%$ \\
\hline \multirow[t]{2}{*}{ Distrito Federal } & & & 13 & $1,6 \%$ & 1 & $0,3 \%$ & 1 & $0,3 \%$ & 7 & $1,6 \%$ & 14 & $3,0 \%$ & 12 & $2,3 \%$ \\
\hline & 669 & $100 \%$ & 807 & $100 \%$ & 427 & $100 \%$ & 447 & $100 \%$ & 446 & $100 \%$ & 467 & $100 \%$ & 545 & $100 \%$ \\
\hline
\end{tabular}

Fonte: Nicolau, Jairo Dados Eleitorais do Brasil (1982-2006) versão digital in http://jaironicolau.iuperj.br/banco2004.html

Até 1994 seis estados podiam coordenar esforços para formar uma coalizão dirigente - São

Paulo, Minas Gerais, Paraná, Rio Grande do Sul, Bahia e Rio de Janeiro. Juntos, estes

estados, detinham cerca de 50\% dos convencionais entre 1982 e 1994. Se contarmos com 
os votos dos membros do diretório nacional e dos representantes do partido no congresso, a coalizão mínima vencedora pode ser ainda menor ${ }^{74}$.

Com exceção de $1989^{75}$, quando o partido se dividiu quanto à candidatura para a sucessão de José Sarney, que assumiu a presidência com a morte de Tancredo Neves, de 1982 até 1994 as decisões foram, em geral, tomadas por unanimidade sem disputas de chapa ${ }^{76}$.

Em 1984 foi aprovada por unanimidade a única chapa de candidatos à presidência encabeçada por Tancredo Neves e tendo como vice José Sarney. Em 1986 e 1989 Ulisses Guimarães é reconduzido à presidência do partido em chapa única ${ }^{77}$.

Em 1989, na convenção que escolheu o nome de Ulisses Guimarães como candidato a presidência, concorreram quatro nomes, Álvaro Dias, do Paraná, Waldir Pires, da Bahia, Ulysses Guimarães, de São Paulo e Íris Rezende, de Goiás. Com a disputa entre três estados com grande número de convencionais não foi fácil chegar a um consenso. Foram necessárias duas votações, na primeira Álvaro Dias e Iris Rezende foram derrotados, na segunda votação Waldir Pires retira sua candidatura em favor da de Ulisses que é escolhido candidato. Nas eleições Ulysses obteve apenas 4,43\% dos votos apesar de contar com 22 minutos no horário gratuito de propaganda eleitoral. A divisão no interior do partido fez

\footnotetext{
${ }^{74}$ Não trazemos estes dados pois seria necessário conhecer a composição do diretório nacional por estado, algo que demanda uma pesquisa mais aprofundada.

${ }^{75}$ As disputas no interior do PMDB também se fizeram presentes durante os trabalhos da constituinte, desde a eleição do líder do partido, Mário Covas, até a divisão quanto a duração do mandato de Sarney. Estas divisões levaram ao rompimento de uma parte do partido que veio a fundar o PSDB. Embora alguns autores defendam que este rompimento se deveu à proximidade das primeiras eleições diretas para presidente desde 1960, acredito que a falta de espaço no partido de origem, principalmente no nível regional, fez com esses parlamentares deixassem o PMDB.

${ }^{76}$ Todas as informações sobre as convenções do PMDB foram extraídas de LEÃO (2002). NÃO ESTÁ NA BIBLIOGRAFIA

${ }^{77}$ Em 1989, na convenção para a escolha do candidato à presidência do partido, Jader Barbalho lança uma chapa contra Ulisses, mas este é eleito com quase a totalidade dos votos
} 
com que Ulysses fizesse a campanha praticamente sozinho, como ele mesmo disse "só vejo um jeito de perder esta eleição: o PMDB derrotar o próprio PMDB” (citado no verbete "Ulysses Guimarães", FGV/CPDOC/DHBB).

Em 1991 Ulysses é novamente eleito presidente do partido em chapa única. Orestes Quércia consegue o mesmo feito em 1993 e em 1994 e, utilizando pela primeira vez o mecanismo de prévias, é indicado candidato à Presidência da República na mesma convenção que delega à Comissão Executiva Nacional a decisão sobre coligações eleitorais.

A partir de 1994 as convenções nacionais do PMDB não conseguem mais decidir sem divisões. Em 1995 o Diretório Nacional, eleito pela Convenção Nacional, se divide ao meio na escolha do presidente do partido. Por 75 votos contra 74, Paes de Andrade, do Ceará, vence Alberto Goldman, de São Paulo. Goldman em seguida iria se unir ao PSDB.

Em 1997, numa convenção extraordinária para decidir a posição do partido quanto à proposta da reeleição a convenção resolve:

1. Reeleição de detentores de mandato no Poder Executivo:

Sim - 229

Não - 343

Brancos -3

2. Em caso afirmativo, deverá ser aplicado aos atuais detentores de mandato: Sim - 190

Não - 135

Abstenções - 17

3. Decisão do Congresso deverá depender de:

Plebiscito - 76

Referendo - 49

Nenhum dos dois - 236

Nulos - 3 
Em 8 de março de 1998 em nova convenção extraordinária o partido novamente se dividiu quanto a lançar ou não candidato à presidência, foram 303 votos a favor e 389 votos contra. A decisão foi adiada e em 28 de junho de 1998 foi realizada nova convenção extraordinária que, no entanto, não obteve quorum, o que fez com que o partido não lançasse candidato e nem deliberasse sobre coligações.

Finalmente, em 2002, após uma relativamente tranqüila eleição de Michel Temer para a presidência do partido em 2001, o partido se dividiu quanto à candidatura à presidência. Apesar da convenção de 2001 ter decidido pela prévia para escolha dos candidatos à presidência e vice-presidência do partido, em 2002 a convenção decidiu pelo apoio ao candidato do PSDB. Essa decisão também é cercada por disputa pois, Paraná e São Paulo se unem, lançando uma chapa com Roberto Requião para presidente e Alda Marco Antônio para vice. Como estes dois estados não tinham mais a mesma força que antes, a coligação com o PSDB e a indicação da Deputada Rita Camata como candidata à vice-presidência da república é aprovada com 433 votos.

O caso do PMDB mostra como um partido de origem parlamentar e fortemente organizado sofre com as divisões internas. Sem o recurso às comissões provisórias e com amplas coalizões mínimas majoritárias, uma coalizão dominante depende de intensa negociação e a tomada de decisão acaba prejudicada.

\section{Partido da Social Democracia Brasileira - PSDB}

O PSDB, por nascer do interior do PMDB, também herda uma organização partidária mais estável nos estados que eram redutos eleitorais de suas lideranças. Nos demais estados o partido ainda se organiza por meio de comissões provisórias. Assim como o PMDB o 
PSDB é um partido regionalizado. Os estatutos dos dois partidos são muito parecidos e o número de delegados à convenção nacional é proporcional ao número de deputados federais de cada estado ${ }^{78}$. Mas, ao contrário do PMDB, no PSDB são poucos os estados que formam sua coalizão dirigente, o que facilita a formação de maioria e as "decisões de cúpula" como pode ser visto na simulação do número de delegados em 2006 na Tabela 5.3.

\footnotetext{
${ }^{78}$ Art. 59. A Convenção Nacional será constituída:

I - dos membros do Diretório Nacional;

II - dos Delegados dos Estados e do Distrito Federal;

III - dos representantes do Partido no Congresso Nacional.

$\S$ 1‥ O número de Delegados de cada Estado e do Distrito Federal será correspondente até o dobro da respectiva representação partidária no Congresso Nacional, acrescido do número de Delegados equivalente a 10 \% (dez por cento) do número de Diretórios Municipais organizados em cada unidade da federação.
} 
TABELA 5.3 - DISTRIBUIÇÃO DO NÚMERO DE DELEGADOS À CONVENÇÃO DO PSDB DE 2006 POR ESTADO (SIMULAÇÃO)

\begin{tabular}{|c|c|c|c|c|c|c|c|c|c|c|}
\hline Estado & 1990 & $\%$ & 1994 & $\%$ & 1998 & $\%$ & 2002 & $\%$ & 2006 & $\%$ \\
\hline AC & 1 & $0 \%$ & 1 & $0 \%$ & 1 & $0 \%$ & 1 & $0 \%$ & 1 & $0 \%$ \\
\hline$A L^{*}$ & 10 & $2 \%$ & 14 & $2 \%$ & 14 & $2 \%$ & 12 & $2 \%$ & 10 & $2 \%$ \\
\hline $\mathrm{AP}$ & 1 & $0 \%$ & 1 & $0 \%$ & 7 & $1 \%$ & 3 & $0 \%$ & 1 & $0 \%$ \\
\hline $\mathrm{AM}^{*}$ & 6 & $1 \%$ & 8 & $1 \%$ & 8 & $1 \%$ & 6 & $1 \%$ & 6 & $1 \%$ \\
\hline $\mathrm{BA}^{*}$ & 46 & $7 \%$ & 50 & $7 \%$ & 54 & $7 \%$ & 46 & $7 \%$ & 46 & $7 \%$ \\
\hline $\mathrm{CE}^{*}$ & 32 & $5 \%$ & 40 & $6 \%$ & 42 & $6 \%$ & 34 & $5 \%$ & 28 & $4 \%$ \\
\hline DF & 2 & $0 \%$ & 0 & $0 \%$ & 2 & $0 \%$ & 0 & $0 \%$ & 0 & $0 \%$ \\
\hline ES* & 14 & $2 \%$ & 12 & $2 \%$ & 14 & $2 \%$ & 12 & $2 \%$ & 10 & $1 \%$ \\
\hline GO* & 25 & $4 \%$ & 27 & $4 \%$ & 29 & $4 \%$ & 35 & $5 \%$ & 33 & $5 \%$ \\
\hline MS & 14 & $2 \%$ & 16 & $2 \%$ & 18 & $2 \%$ & 14 & $2 \%$ & 16 & $2 \%$ \\
\hline MA* & 24 & $4 \%$ & 26 & $4 \%$ & 28 & $4 \%$ & 26 & $4 \%$ & 30 & $4 \%$ \\
\hline MT & 8 & $1 \%$ & 10 & $1 \%$ & 14 & $2 \%$ & 14 & $2 \%$ & 10 & $1 \%$ \\
\hline MG* & 96 & $16 \%$ & 100 & $15 \%$ & 112 & $15 \%$ & 100 & $15 \%$ & 98 & $15 \%$ \\
\hline $\mathrm{PA}^{*}$ & 14 & $2 \%$ & 14 & $2 \%$ & 22 & $3 \%$ & 22 & $3 \%$ & 20 & $3 \%$ \\
\hline $\mathrm{PB}^{*}$ & 22 & $4 \%$ & 22 & $3 \%$ & 24 & $3 \%$ & 28 & $4 \%$ & 28 & $4 \%$ \\
\hline $\mathrm{PR}^{*}$ & 48 & $8 \%$ & 42 & $6 \%$ & 50 & $7 \%$ & 50 & $7 \%$ & 48 & $7 \%$ \\
\hline PE & 15 & $2 \%$ & 17 & $3 \%$ & 17 & $2 \%$ & 21 & $3 \%$ & 19 & $3 \%$ \\
\hline $\mathrm{PI}^{*}$ & 24 & $4 \%$ & 22 & $3 \%$ & 24 & $3 \%$ & 26 & $4 \%$ & 24 & $4 \%$ \\
\hline $\mathrm{RN}^{*}$ & 19 & $3 \%$ & 19 & $3 \%$ & 17 & $2 \%$ & 17 & $2 \%$ & 17 & $2 \%$ \\
\hline RS & 40 & $7 \%$ & 42 & $6 \%$ & 42 & $6 \%$ & 42 & $6 \%$ & 42 & $6 \%$ \\
\hline RJ & 11 & $2 \%$ & 21 & $3 \%$ & 31 & $4 \%$ & 19 & $3 \%$ & 15 & $2 \%$ \\
\hline RO & 6 & $1 \%$ & 12 & $2 \%$ & 10 & $1 \%$ & 8 & $1 \%$ & 6 & $1 \%$ \\
\hline $\mathrm{RR}$ & 2 & $0 \%$ & 4 & $1 \%$ & 6 & $1 \%$ & 2 & $0 \%$ & 4 & $1 \%$ \\
\hline SC & 30 & $5 \%$ & 30 & $4 \%$ & 32 & $4 \%$ & 30 & $4 \%$ & 32 & $5 \%$ \\
\hline SP & 83 & $13 \%$ & 95 & $14 \%$ & 95 & $13 \%$ & 87 & $13 \%$ & 101 & $15 \%$ \\
\hline $\mathrm{SE}^{*}$ & 8 & $1 \%$ & 8 & $1 \%$ & 10 & $1 \%$ & 10 & $1 \%$ & 10 & $1 \%$ \\
\hline TO* & 16 & $3 \%$ & 14 & $2 \%$ & 16 & $2 \%$ & 18 & $3 \%$ & 18 & $3 \%$ \\
\hline Total & 615 & $100 \%$ & 665 & $100 \%$ & 737 & $100 \%$ & 681 & $100 \%$ & 671 & $100 \%$ \\
\hline
\end{tabular}

Esta tabela mostra que dois estados, São Paulo e Minas Gerais, detêm 30\% do total de delegados. Esse número é significativo se pensarmos que no PMDB, a partir de 1998, eram necessários, no mínimo, quatro estados para se obter a mesma quantia. A preponderância 
destes dois estados garante maior facilidade no estabelecimento de coalizões mínimas vencedoras.

No momento original em que poucas figuras partidárias eram conhecidas nacionalmente e podiam pleitear a presidência da república, a união da coalizão dirigente do partido não era problemática. Esse fato pode ser visto na decisão sobre a aliança com o PFL (atual DEM) para a disputa à presidência. Apesar de polêmica e de haver grandes nomes de peso do partido contrários à idéia, a convenção aprovou a coligação sem muitos problemas ${ }^{79}$.

Depois de sua passagem pela presidência (1995-2002) e com novos nomes de grande força eleitoral o partido começou a sofrer com divisões e disputas, que, no entanto, continuam sendo resolvidas por acordos na cúpula. A grande mudança ocorreu na disputa pela presidência em 2006 quando Geraldo Alckmin, então governador de São Paulo, pleiteou lançar seu nome às prévias partidárias contra o nome de José Serra que contava com o apoio da cúpula, o chamado "triunvirato" ${ }^{80}$. Como os votos dos convencionais de São Paulo estavam divididos, a cúpula teria dificuldades em conseguir maioria. A idéia das prévias passou a ganhar apoio de outros líderes partidários de menor expressão, como Marconi Perillo, governador de Goiás, Cássio Cunha Lima, governador da Paraíba, e Simão Jatene, governador do Pará, apoio esse que aumentou a incerteza quanto a uma vitória de Serra. Em vista disso, José Serra retirou seu nome para se candidatar ao governo do estado.

\footnotetext{
${ }^{79}$ A exceção é a de Juthay Magalhães que, grande inimigo do cacique do PFL baiano, Antonio Carlos Magalhães, abre seu palanque para o candidato do PT.

${ }^{80}$ A denominação "triunvirato" foi dada ao trio formado por Fernando Henrique Cardoso, ex-presidente da República, Tasso Jereissati, presidente do partido e Aécio Neves, governador de Minas Gerais, que se reunia para tomar as decisões referentes à candidatura à presidência do PSDB.
} 
No nível regional há diferenças em termos de divisões internas e a presença de comissões provisórias pode explicar diferenças no grau de coesão e controle de suas direções. É o caso das diferenças entre os estados de São Paulo e Minas Gerais. O PSDB em São Paulo contém $22 \%$ de comissões provisórias, enquanto em Minas possui $46 \%$.

Em São Paulo, a disputa entre Serra e Alckmin, iniciada em 2006, se repetiu em 2008 quando da escolha do candidato à prefeitura. Setores do partido, comandados por Serra, queriam apoiar o então prefeito Gilberto Kassab (DEM) pensando em uma aliança que favoreceria Serra em 2010 caso ele fosse candidato à presidência. Outra parte queria a candidatura própria já que o partido havia conquistado a prefeitura em 2004, detinha o governo do estado e tinha um candidato entre os primeiros colocados nas pesquisas eleitorais. A questão foi decidida pelas bases partidárias que apoiaram em peso a candidatura própria fazendo com que a idéia de se apresentar uma chapa de apoio à Kassab fosse descartada. A candidatura própria teve cerca de $80 \%$ dos votos dos convencionais. Em Minas a decisão do partido foi no sentido oposto do que ocorreu em São Paulo. Decidiu-se apoiar a candidatura do PSB para a prefeitura de Belo Horizonte em uma aliança com o PT local. Como o PSDB fazia, na época, oposição ao PT no nível federal a direção nacional deste último vetou a aliança e a candidatura do PSB só vingou porque o PSDB se retirou formalmente da aliança passando a dar apoio informal.

A capacidade da direção regional em comandar todos estes movimentos em torno da candidatura do PSB mostra seu poder dentro do PSDB local, o que se torna compreensível tendo em vista a grande quantidade de comissões provisórias. Esta notícia do jornal "Estado do Triângulo" explica o porquê essas comissões serem tão numerosas: 
Uma decisão da cúpula tucana de Minas Gerais, atendendo pedido dos deputados eleitos nas últimas eleições, decidiu extinguir, a partir do dia 16 de julho, todos os diretórios do PSDB no interior do estado. Segundo o então presidente do PSDB, o vice-prefeito Pedro Teodoro Rodrigues, não houve nenhuma justificativa. "Um telegrama nos informava apenas a determinação do diretório estadual para não se realizar a convenção no dia 15 de julho e que uma comissão provisória seria indicada posteriormente. Dias após, a mídia noticiou que muitos diretórios municipais do PSDB, em Minas Gerais estariam extintos a partir do dia 16”, explicou Dr. Pedro. A decisão, considerada arbitrária pelos integrantes do diretório local, atendia a um pedido dos deputados eleitos, que pleiteavam os partidos das cidades de sua área de abrangência. Em Sacramento, o PSDB ficou nas mãos do deputado estadual, majoritário, Fahim Sawan. O resultado foi desastroso para o PSDB, imediatamente, cerca de 100 filiados deixaram o partido na cidade e debandaram para o PV, cuja comissão provisória está formada pelo vice-prefeito Pedro Teodoro Rodrigues de Rezende, Jaime Eduardo Araújo, Wilmar Afonso Lacerda, Virgínia Dolabela de Lima, Otto Cesar Freitas Pereira, Maria Aparecida Varanda e Eurípedes dos Reis Ferreira (O ESTADO DO TRIÂNGULO, 09 Setembro de 2007).

Esse exemplo mostra que o PSDB, apesar de contar com uma proporção relativamente baixa de comissões provisórias, apresenta algumas vezes, no nível regional, características de um partido não organizado com grande concentração de poder nas direções regionais. Quando isso ocorre a coordenação fica mais fácil que em locais mais organizados, como São Paulo. 


\section{Partidos oligárquicos de organização mista}

Assim como os partidos organizados os de organização mista são heterogêneos compreendendo o PDT, partido fundado por Leonel Brizola e considerado de esquerda por vários analistas, e dois partidos de direita, o PP e o DEM, oriundos da antiga ARENA, partido de sustentação dos governos militares.

Todos esses partidos possuem coalizões dirigentes que detém um enorme poder e, por isso mesmo, é raro ouvir falar em disputas no seu interior. O PDT, como veremos, fundado por Brizola e principal instrumento pelo qual seu líder buscou viabilizar sua candidatura a presidente, participou mais vezes das disputas pela presidência. Os outros dois partidos raramente lançam candidatos próprios para a presidência da república, participando em geral de alianças, disputando somente os votos em seus redutos.

\section{Partido Democrático Trabalhista - PDT}

O PDT nasceu a partir da liderança de Leonel Brizola. Uma das maiores lideranças da esquerda do antigo PTB, Brizola, após sua volta do exílio em 1979, tentou retomar a legenda em uma disputa com Ivete Vargas líder do PTB paulista. Ivete ganhou o direito à legenda e Brizola fundou o PDT.

O partido tem sua maior força eleitoral nos estados do Rio Grande do Sul, governado por Brizola entre 1962 e 1964, e no Rio de Janeiro, onde Brizola governou entre 1982 e 1986. Fora destes estados imperam as comissões provisórias e se torna muito difícil discernir a posição ideológica de suas lideranças. 
Por ser um partido construído por um líder carismático o PDT possui regras de escolhas de dirigentes que dão grande poder para a Comissão Executiva Nacional, comandada por Brizola. Diferente dos casos do PT, PMDB e PSDB o estatuto do partido deixa a critério da executiva a fixação do número de delegados à Convenção Nacional ${ }^{81}$. Como também é a executiva quem nomeia as comissões provisórias, ela acaba por deter total controle sobre o partido.

Outra mostra de poder da executiva do partido se deu em 2002 quando o partido criou uma Comissão Eleitoral Nacional com poderes de revogar qualquer decisão das convenções regionais que estivesse contra a decisão da comissão executiva nacional sobre as eleições daquele ano, inclusive dissolvendo as comissões executivas regionais e instaurando comissões provisórias em seu lugar ${ }^{82}$.

Mesmo com todo esse poder a liderança de Leonel Brizola foi questionada algumas vezes, pois para viabilizar sua candidatura à presidência da república Brizola teria que contar com apoio de algumas lideranças fortes. No entanto, a concentração de poder nas mãos do líder sempre fez com que as disputas fossem resolvidas a seu favor.

O então prefeito do Rio de Janeiro Marcello Alencar teve que deixar o partido em 1992 após questionar a indicação de Cidinha Campos para lhe suceder. O prefeito César Maia

\footnotetext{
${ }^{81}$ Conforme o estatuto do partido em seu Artigo 20:

"Compete à Executiva Nacional a fixação de:

a) data das Convenções Estaduais e Municipais;

b) número de delegados à Convenção Nacional, por unidade da Federação, de acordo com o número de filiados e o desempenho eleitoral do partido;

c) número de membros dos Diretórios Estaduais;"

${ }^{82}$ Resolução PDT/CEN № 26, de março de 2002.
} 
também teve que abandonar o partido após apoiar o plano Collor em 1991, contra a orientação de Brizola. O mesmo se passou com Saturnino Braga.

Em 2000 Brizola teve que disputar espaço com Anthony Garotinho, então governador do Rio de Janeiro, que decidiu não apoiar sua candidatura a prefeito da capital carioca. Conforme reportagem da revista Veja:

(Brizola) propôs a expulsão do governador do PDT (...) agora, a palavra final da contenda está com a Justiça. Garotinho entrou com uma ação para impedir que o diretório estadual do PDT, controlado a ferro e fogo por Brizola, possa expulsá-lo do partido. O que torna esse embate mais perigoso para Brizola é que pela primeira vez ele tem um adversário que não está disposto a deixar o partido em busca de espaço. Garotinho sabe que o PDT é o caminho mais seguro para ajudálo na corrida presidencial. O PMDB, por exemplo, tende a se aliar ao PSDB e não lançar candidato próprio à Presidência da República, atrapalhando seus planos de chegar ao Planalto. 'Não sou como os outros. Não vou deixar o PDT', disse o governador (Veja online 16/08/2000).

Em 2001, Garotinho deixou o partido, mais uma vitória de Brizola apesar de estar eleitoralmente enfraquecido, obteve apenas $10 \%$ dos votos nas eleições municipais de 2000.

Além da fraqueza eleitoral de Brizola o próprio PDT se encontrava em declínio na época deste conflito e começava a perder integrantes mesmo em seus redutos como o Rio de Janeiro e o Rio Grande do Sul. A Tabela 5.4 mostra a evolução do número de 
governadores, cadeiras na Câmara Federal e votação para deputado federal do partido entre 1994 e 2004, ano da morte de Brizola.

TABELA 5.4 EVOLUÇÃO DA VOTAÇÃO NA LEGENDA DO PDT PARA DEPUTADO FEDERAL, NÚMERO DE CADEIRAS NA CÂMARA DOS DEPUTADOS E NÚMERO DE GOVERNADORES

\begin{tabular}{lrrrrrr} 
& 1982 & 1986 & 1990 & 1994 & 1998 & 2002 \\
\hline Votos para Deputado Federal & 2.394 .723 & 3.075 .429 & 4.068 .078 & 3.237 .289 & 3.774 .511 & 4.482 .528 \\
Cadeiras & 23 & 24 & 46 & 34 & 25 & 21 \\
Governadores & 1 & & 3 & 2 & 1 & 1 \\
\hline
\end{tabular}

Fonte: Nicolau, Jairo Dados Eleitorais do Brasil (1982-2006) versão digital in http://jaironicolau.iuperj.br/banco2004.html

A situação do partido na ocasião da morte de Brizola estava um pouco pior do que na origem do partido. Depois de ter atingido seu ápice, em termos de representação, governando em três estados e contando com 46 deputados federais sua a situação começou a mudar a partir daí. Em 1998, foram apenas 25 deputados e em 2002 21, no pior desempenho de sua história.

A força de Brizola no PDT se explica em boa parte pela precariedade da organização partidária. Na sua origem e durante toda sua vida o partido se baseou em comissões provisórias. Mesmo no Rio de Janeiro esse tipo de organização imperava em $79 \%$ do total de municípios em que o partido estava presente. Neste caso a força advinda da precariedade organizacional também correspondeu a uma maior rigidez do partido. 
O grau de controle que as comissões provisórias dão aos dirigentes do partido é tão grande que, conforme reportagem do jornal Folha de São Paulo, algumas vezes nomeações eram trocadas por por dinheiro, conforme relato a seguir:

A cúpula do PDT paulista vem destituindo de forma sistemática vários políticos ligados ao deputado estadual Geraldo Vinholi (PDT-SP) dos comandos regionais do partido. Alguns dos afastados estão no PDT há quase 30 anos. As destituições, diz Vinholi, atingiram cerca de 40 comissões provisórias do PDT no Estado e a legenda acabou sendo negociada com outros políticos mediante pagamentos a pessoas ligadas ao presidente do partido em São Paulo, o deputado federal Paulo Pereira da Silva, o Paulinho. João Farias, ex-integrante do PDT em Araraquara, diz em documento enviado à secretaria geral da sigla que lidava com "verdadeiros batedores de carteira", que exigiam dinheiro para que ele e outros políticos locais permanecessem à frente do partido (FOLHA DE SÃO PAULO, 07/05/2008).

Essa força fez com que o PDT ora lançasse candidato ora estabelecesse alianças conforme a estratégia traçada por seu líder para chegar à presidência.

\section{Democratas - DEM}

O Democratas, ao contrário do PDT, é um partido de origem parlamentar. Surgiu em 1985 de uma cisão do PDS (hoje PP) com o nome de Partido da Frente Liberal (PFL). O PFL estava fortemente baseado nos estado do Nordeste e seu caráter regional era reforçado por um estatuto que, assim como no PSDB e PMDB, estabelecia um número de delegados 
proporcional às bancadas na Câmara Federal ${ }^{83}$. Mas, apesar de seu caráter regional e ao contrário do PMDB e diferente do PSDB, o partido sempre apresentou grande coesão interna.

Essa coesão se explica em parte pela preponderância das comissões provisórias e em parte pela preponderância de alguns estados na sua formação. Como vimos mais acima 9 de 21 estados onde o DEM estava presente estavam organizados com comissões provisórias, quase $50 \%$ do total dos estados e $27,7 \%$ do total de delegados. Isso quer dizer que a comissão executiva tem grande controle sobre o partido, pois com os votos do diretório nacional e dos parlamentares consegue facilmente construir uma maioria ${ }^{84}$.

A força da coalizão dominante pode ser sentida na prática, nada incomum, de dissolução de diretórios. A resolução que reproduzimos abaixo trata da dissolução do diretório de Goiás:

\footnotetext{
${ }^{83}$ Conforme o Artigo 37 do estatuto

"O número de Delegados de cada Estado e do Distrito Federal corresponderá ao dobro de sua representação no Congresso Nacional. Parágrafo único - É assegurado aos Estados e ao Distrito Federal onde o Partido tiver Diretório organizado o direito a, no mínimo, dois Delegados".

${ }^{84}$ Conforme o estatuto do DEM:

“Art. 34 - São competentes para designar Comissões Provisórias:

I - A Comissão Executiva Nacional designará as Comissões Provisórias para organizar Diretórios Estaduais e os Órgãos de Ação Partidária nacionais;

II - As Comissões Executivas Estaduais designarão as Comissões Provisórias para organizar Diretórios Municipais e os Órgãos de Ação Partidária estaduais; e

III - As Comissões Executivas Municipais designarão as Comissões Provisórias para organizar os Órgãos de Ação Partidária municipais.

Parágrafo único - No caso de omissão das Executivas Estaduais ou Municipais, a Executiva Nacional poderá designar qualquer Comissão Provisória Estadual ou Municipal. Poderá ainda destituí-las, para o fim de resguardar o interesse e a integridade partidária".
} 


\section{Resolução N. ${ }^{\circ}$ 371, de 14/06/2006}

A Comissão Executiva Nacional do Partido da Frente Liberal - PFL, no uso das suas atribuições previstas no art. 105 do Estatuto do Partido, após cumprido o rito ordinário, mediante o qual se assegurou a ampla defesa às partes; e considerando que aprovado, pela Comissão Executiva Nacional, o parecer do Senador César Borges, Relator do Processo Administrativo no 004/2006, pela procedência da Representação, para a dissolução do Diretório Regional do PFL de Goiás RESOLVE:

Art. $1^{\circ}$ Dissolver o Diretório Regional do PFL do Estado de Goiás.

Art. $2^{\circ}$ Designar Comissão Provisória Regional com a seguinte composição: Presidente - Ronaldo Ramos Caiado (“....)"

A dissolução de diretórios servia para acomodar forças que naquele momento histórico serviriam melhor à estratégia partidária, como o caso de Caiado em Goiás, Francisco Chagas Freitas no Acre, José Bianco em Rondônia e Kátia Abreu em Tocantins.

Por outro lado, o fato do PFL ter nascido das articulações de três líderes - Jorge Bornhausen de Santa Catarina, Marco Maciel de Pernambuco e Guilherme Palmeira de Alagoas (CANTANHEDE, 2001) - que juntos sempre detiveram mais de 20\% dos convencionais, permitiu a coesão da própria comissão executiva nacional. 
Com a mudança de nome e de estatuto o partido se renovou, dissolveu todos seus diretórios estabelecendo comissões provisórias em seu lugar. Neste processo as posições de poder foram fortalecidas e o partido pode preparar sua estratégia para as eleições de 2008.

\section{Partido Progressista - PP}

O PP está fortemente baseado sobre comissões provisórias. Com exceção de Rio Grande do Sul e Santa Catarina, o partido conta com mais de $60 \%$ de comissões provisórias nos estados em que está presente. Embora sua estrutura esteja baseada em comissões provisórias, o que dá um grande poder à Comissão Executiva Nacional, como no caso do DEM, esta Executiva não tem um centro claro de poder. Enquanto no DEM poucas lideranças formavam a cúpula do partido, no PP as forças estavam mais pulverizadas e equilibradas. O número de delegados dos diretórios regionais é menor que nos outros partidos enquanto que os presidentes destes diretórios e os das comissões provisórias têm assento garantido na convenção ${ }^{85}$. Assim, embora o instituto da comissão provisória

\footnotetext{
${ }^{85}$ Conforme o estatuto do PP

“Art. 8․ A Convenção Nacional é o órgão supremo do Partido e é constituída:

I - dos membros do Diretório Nacional;

II - dos representantes do partido no Congresso Nacional;

III - dos delegados dos Estados e do Distrito Federal, eleitos pelas respectivas convenções;

IV - dos Presidentes dos Diretórios Estaduais;

V - dos Presidentes das Comissões Provisórias Estaduais;

VI - dos Presidentes nacionais dos órgãos de apoio do Partido.

$\S 1$ 1 Serão 2 (dois) os Delegados da Convenção Nacional, mais o equivalente ao número de representantes no Congresso Nacional, Assembléia Legislativa ou Câmara Distrital, com domicílio na respectiva unidade federativa, e suplentes em igual número, convocados pela ordem cronológica de sua colocação na chapa.
} 
permita o controle sobre delegados a proporção deste controle é menor, pois o número de delegados é menor.

A história de formação do atual Partido Progressista é uma verdadeira sopa de letrinhas, sempre à direita, e que pode ser resumida da seguinte forma: com o começo da abertura política no Brasil, em 1979, a Arena e o MDB foram extintos pelo governo, restabelecendose no país o pluripartidarismo. A maioria dos membros da extinta Arena fundou o Partido Democrático Social - PDS que, com a saída dos políticos que iriam formar o PFL em 1985, foi dominado por Paulo Maluf, candidato à Presidência em 1985 contra Tancredo Neves.

A fusão, em 1993, do PDS com PDC resultou no Partido Progressista Reformador - PPR. O PPR permitiu que Maluf, agora na liderança da nova agremiação e que pretendia novamente se lançar à Presidência, contasse com 73 deputados federais e dez senadores, 0 que lhe daria um bom tempo de televisão na campanha.

Em 1994, o PTR fundiu-se com o PST, formando o Partido Progressista - PP, e com a fusão do PPR e PP, em 1995, fundou-se o Partido Progressista Brasileiro - PPB. Estas fusões novamente seguiram a lógica eleitoral de Maluf, que acabara não se lançando candidato em 1994, mas pretendia concorrer em $1998^{86}$. Para isso deveria derrotar o projeto de reeleição do Presidente Fernando Henrique Cardoso.

Maluf, no entanto, estava desgastado devido a acusações de corrupção contra seu exsecretário e sucessor na prefeitura de São Paulo, Celso Pitta e contra sua mulher Sylvia. Assim, na votação do projeto da reeleição "FHC conseguiu 44 votos a favor na bancada do próprio $\mathrm{PPB}$, mais que os 43 deputados que permaneceram fiéis a Maluf (..) a derrota

\footnotetext{
${ }^{86}$ O candidato do partido em 1994, Esperidião Amin amargou uma 6o colocação.
} 
obrigou Maluf a adiar a disputa pela Presidência" (PULS, 2000:65). Maluf chega, portanto, enfraquecido na última convenção nacional do PPB, realizada em 2003, que decidiu mudar novamente o nome do partido para PP (Partido Progressista).

A incorporação e fusão destas diversas legendas fizeram com que a cúpula partidária fosse mais heterogênea que a dos outros partidos oligárquicos. No entanto, esta heterogeneidade aumenta a ocorrência de disputas no interior desta cúpula.

A disputa no interior da coalizão dirigente já se fez sentir em 2003, ano da fundação do PPB, nas discussões em torno da adesão ou não ao governo Lula e, no nível regional, na disputa entre Paulo Maluf e Celso Russomano pelo controle da legenda em São Paulo.

A convenção que mudou o nome do partido resultou ainda na eleição, em chapa única, do deputado Pedro Corrêa (PE) como novo presidente. O ex-líder Paulo Maluf (SP) deixou o posto, mas seguiu como presidente de honra. Conforme reportagem do jornal Folha de São Paulo "Corrêa afirmou após sua eleição que o partido estava desgastado, e por isso trocou de nome. Ele lembrou que o número de deputados vinha caindo ano após ano. Nas últimas eleições, por exemplo, de 49 caiu para 47 os eleitos. Por conta da mudança, o novo presidente disse que a quantidade de deputados irá aumentar podendo chegar a 60 até junho daquele ano (2003)".

O PP sob o comando de Correa decide se unir ao governo Lula e em 2005 elege um de seus membros, o deputado Severino Cavalcanti, presidente da Câmara. Com sua ascensão ao poder, Severino e um grupo de pepistas tentou desbancar o ex-presidente e atual “presidente de honra" do partido, Paulo Maluf, nomeando Celso Russomano, adversário local do malufismo, para presidente do partido em São Paulo. 
Entretanto, Severino e outros membros de destaque do partido (com José Janene e Pedro Henry, líder do partido na Câmara) foram denunciados em graves esquemas de corrupção. Isto, somado à eleição de Maluf para deputado com mais de 800 mil votos, fez com que este, apesar de também acumular problemas com a justiça, recuperasse seu prestígio e também levou a que, em 2007, Russomano fosse destituído da presidência regional do partido em favor do próprio Maluf, que acabou sendo lançado candidato à prefeitura da capital paulista em 2008 .

Esse jogo entre lideranças só foi possível pelo fato do partido sempre ter se constituído enquanto comissão provisória na cidade de São Paulo, o que, durante bom tempo, garantiu o domínio malufista. O caráter provisório do PP é mantido não tanto por dissoluções de diretórios ad hoc como no caso do PFL, mas por meio das várias fusões e mudanças de nome do partido. Cada mudança de nome e cada fusão ${ }^{87}$ geram mudanças no estatuto e são motivos para a reestruturação partidária com a destituição dos diretórios em vigor e a nomeação de novas comissões provisórias. Foi o que aconteceu com o DEM quando abandonou o nome PFL e é o que aconteceu com o PTB em mais de uma fusão, como veremos a seguir.

\footnotetext{
${ }^{87}$ Conforme a Lei 9.096 de 1995, a Lei dos Partidos, "fica cancelado, junto ao Ofício Civil e ao Tribunal Superior Eleitoral, o registro do partido que, na forma de seu estatuto, se dissolva, se incorpore ou venha a se fundir a outro", a Lei também especifica que "havendo fusão ou incorporação de partidos, os votos obtidos por eles, na última eleição geral para a Câmara dos Deputados, devem ser somados para efeito do funcionamento parlamentar".
} 


\section{Partidos Monocráticos não organizados}

\section{Partido Trabalhista Brasileiro - PTB}

Em 1979, com a volta do multipartidarismo, dois grupos diferentes tentaram retomar a sigla PTB que, durante o período de 1945 a 1966 tinha sido um dos maiores partidos do país com amplo apoio popular. Um dos grupos era capitaneado por Leonel Brizola que, como vimos, veio a fundar o PDT, o outro capitaneado por Ivete Vargas conseguiu o registro definitivo da sigla.

Enquanto Brizola conseguiu rapidamente estruturar o partido, Ivete teve que esperar bastante tempo até conseguir estabelecer comissões provisórias no mínimo de nove estados, requisito da Lei Orgânica dos Partidos. Ainda assim, em agosto de 1982, o PTB já possuía a terceira maior bancada do Congresso com 14 deputados e dois senadores, número que cai para 13 deputados e nenhum senador nas eleições daquele ano.

A atuação do PTB no Congresso foi, desde o começo, pautada pela barganha. Sempre disputado para compor maiorias o partido trocava apoio por cargos. Segundo o Dicionário Histórico Biográfico Brasileiro da FGV, em 1983 o PTB foi o fiel da balança na disputa sobre o Decreto 2.065 que previa faixas de reajustes salariais para os trabalhadores. $\mathrm{O}$ Governo possuía 235 votos contra 231 da oposição, o PTB, com seus 13 votos, decidiria o resultado. O partido resolveu apoiar o governo e em troca recebeu cargos em empresas como a Telesp, Light e Cobal. 
O PTB desde então não deixou mais de apoiar o governo. Em 1985 apoiou Sarney e recebeu o governo de Roraima, em 1990 apoiou o governo de Fernando Collor de Mello e após o impeachment participou do governo de Itamar Franco indicando seu presidente, José Andrade Vieira, para o Ministério da Indústria e Comércio. Em 1995, Andrade Vieira passou a ocupar o Ministério da Agricultura no governo de Fernando Henrique Cardoso. No governo Lula o partido continuou "situação" e protagonizou um grande escândalo de corrupção denunciado por Roberto Jefferson, presidente do PTB na época ${ }^{88}$.

A facilidade com que o partido adere a governos que vão da direita à esquerda sem grandes disputas internas, a capacidade da direção partidária em ditar as estratégias partidárias derivam de mecanismos de controle estrito sobre o partido e esses mecanismos são as comissões provisórias.

O estatuto do PTB se baseia em uma estrutura verticalizada onde as bases, constituídas em diretórios, escolhem delegados para as instâncias superiores. O que acontece no PTB é que às vésperas das convenções partidárias os diretórios são dissolvidos e são instauradas comissões provisórias, como ocorreu em $2006^{89}$ :

\footnotetext{
${ }^{88}$ Segundo declarações de Roberto Jefferson o governo pagaria uma mesada de $\mathrm{R} \$ 30$ mil para que os deputados da base aliada votassem com o governo.

${ }^{89}$ A ordem das resoluções segue da mais atual para a mais antiga para reforçar que a atual desorganização do partido não é algo conjuntural e sim algo que ocorre há anos de forma deliberada.
} 
RESOLUÇÃO PTB/CEN Nº 044/2006

A Convenção Nacional do PTB, considerando a necessidade de reestruturação dos órgãos partidários em todas as instâncias diante da incorporação do PAN ao PTB, resolve:

Art. $1^{\circ}$ - Ficam dissolvidos os diretórios e comissões provisórias municipais, zonais, distritais e estaduais do PTB, em todos os estados, municípios e no Distrito Federal.

Art. 2ㅇ - Caberá à Comissão Executiva Nacional a designação de comissões provisórias estadual e distrital.

(...)

Mas que já havia ocorrido em 2003:

RESOLUÇÃO PTB/CEN № 033/2003.

Dispõe sobre a realização de convenções municipais, zonais e estaduais do PTB e regulamenta as disposições do artigo 21 do código partidário.

Art. 10 - Ficam suspensas, por tempo indeterminado, a realização das convenções municipais, zonais, estaduais e distrital de que trata o artigo 21 do estatuto.

$(\ldots)$

Pelas passagens acima fica claro um padrão. Primeiro o partido convoca as convenções que escolhem os diretórios, em seguida elas são extintas, sendo que em 2003 e 2006 a justificativa foi a mesma: a incorporação de outros partidos, no caso o PAN e o PSD. Mesmo quando os diretórios não são dissolvidos a Comissão Executiva Nacional edita resoluções que submetem à sua aprovação a criação de diretórios como ocorreu em 1996, que reproduzimos abaixo e em 2001. 
RESOLUÇÃO PTB-CEN 001, DE 1996

Dispõe sobre o registro de Diretórios do Partido eleitos em Convenção, e dá outras providências.

A COMISSÃO EXECUTIVA NACIONAL DO PARTIDO TRABALHISTA BRASILEIRO - PTB, no uso de suas atribuições estatutárias e considerando o disposto pelo Artigo 41, I e II, do Estatuto Partidário,

\section{$\underline{\text { RESOLVE }}$}

Art. 10 - O registro dos Diretórios eleitos em Convenções será efetuado:

I - perante as Comissões Executivas Estaduais, no caso de Diretórios Municipais ou Zonais;

II - perante a Comissão Executiva Nacional, no caso do Diretório Nacional e Diretórios Estaduais.

\section{(...)}

Art. 40 - Da decisão da Comissão Executiva que denegar pedido de registro de Diretório eleito em Convenção, caberá recurso para o Diretório correspondente no prazo de 10 (dez) dias (Estatuto, Art. 136).

Art. 5o - Deferido o pedido pela Comissão Executiva, o registro de Diretório eleito em Convenção será processado em livro próprio aberto, encerrado, e rubricado pelo Presidente da Comissão Executiva correspondente.

Tendo em vista que o PTB possui mais de um milhão de filiados, mais que o PDT e o

DEM, é difícil de acreditar que a prevalência de comissões provisórias no partido se deva ao fato do partido não conseguir se estruturar. É mais plausível que haja uma estratégia da direção partidária de impedir sua estruturação visando aumentar seu controle sobre a organização. 


\section{Conclusão}

Um exame mais atento da organização dos partidos brasileiros mostra que a tese da ausência de vida partidária está equivocada. A idéia de que os partidos só funcionam durante as eleições não corresponde aos fatos levantados. Há vida partidária embora ela se manifeste de forma diferente nos diferentes partidos.

Esta vida partidária se dá ao redor do controle dos diretórios, pois quem controla os diretórios controla as convenções e, com elas, as instâncias de deliberação e de decisão. Em alguns partidos esse controle é cercado de disputa enquanto em outros uma coalizão dominante, ou um único líder, detém o controle absoluto das decisões. A diferença está no grau de organização dos partidos.

Quanto mais organizado um partido, mais descentralizado ele é, mais sujeito ele está a disputas internas, e mais difícil o controle sobre as estratégias partidárias por parte das lideranças, quanto menos organizado maior o controle. Partidos fortemente organizados são fracos quanto à capacidade de controle e partidos fracamente organizados são fortes, daí o título desta tese: a força dos "partido fracos".

No caso do PT e do PMDB, por não utilizarem o mecanismo das comissões provisórias, as divisões internas se revelaram intensas. No PT essas disputas foram institucionalizadas nas tendências e a dominação de uma coalizão dirigente só foi possível pelas mudanças nas regras de escolhas de dirigentes. Essas mudanças correspondem, às mudanças nas organizações partidárias apontadas por Katz e Mair (1995). Conforme estes autores no "partido de cartel” os líderes, no seu desejo de maior autonomia, devem procurar 
"neutralizar" os membros mais "ideológicos do partido" que podem fazer objeções a estratégias eleitorais mais abrangentes. Para isso, os líderes passam a democratizar o partido, permitindo a participação de um maior número de pessoas nos processos decisórios e fazendo cada vez menos exigências para essa participação ${ }^{90}$.

No PMDB não havia um grupo predominante na origem do partido e, portanto, não foi possível implantar um arranjo institucional que permitisse o surgimento de uma coalizão dominante, pois, com o poder equilibrado entre os diversos grupos, se instaurou um problema quase insolúvel de escolha social, isto é, não foi possível formar uma coalizão mínima vencedora. Neste partido a força está no nível local e regional e as decisões no nível nacional dependem da formação de amplas coalizões internas, daí a paralisia decisória que toma conta do partido e se revela nas divisões quanto às estratégias eleitorais e quanto ao apoio ao governo.

O PSDB, que também conta com relativamente poucas comissões provisórias em sua organização justamente por ter herdado alguma organização de seu partido de origem, o PMDB, após um grande período em que passou incólume pelas disputas internas enfrenta, hoje, divisões que cada vez mais se tornam públicas. Ainda há o predomínio dos grupos paulista e mineiro no partido, mas as decisões de cúpula são cada vez mais questionadas pelas bases $^{91}$.

\footnotetext{
${ }^{90}$ Essa democratização, no entanto, é ilusória, pois as lideranças ainda têm a prerrogativa de apresentar as listas que serão votadas ou nomear os candidatos à direção, etc.(Cf. MAIR, 1997).

${ }^{91}$ Às vésperas das eleições de 2010 o PSDB vive, segundo os noticiários, o problema de decidir se lança como candidato José Serra ou Aécio neves por consulta prévia. Essa dificuldade esbarra na dificuldade de se definir quem teria o direito de votar neste processo. Os dois pré-candidatos reconhecem que recorrer a todos os filiados seria problemático, mas enquanto para Serra um processo restrito aos membros do
} 
No caso dos partidos de organização mista as disputas são raras e se dão naquelas agremiações em que o processo de criação ou de evolução partidária incorporou novos grupos. Quando há disputas a direção partidária se aproveita da precariedade da organização para impor sua vontade. O PDT foi organizado sob a égide de Brizola e as poucas disputas, de caráter local, foram facilmente resolvidas por ele. O DEM, de origem parlamentar e dominado por um pequeno grupo quase não vê disputas internas. Já o PP enfrenta maiores disputas e sempre as resolve de maneira brusca. Este partido não só herdou alguma estrutura de diretórios do PDS como também a estrutura de outros partidos com os quais se fundiu. As disputas se dão entre esses grupos, mas são resolvidas facilmente com a intervenção da direção nacional devido ao seu caráter majoritariamente provisório.

Partidos não organizados como o PTB, dominado pelo grupo de parlamentares, possui um poder quase arbitrário sobre seus membros graças à prevalência das comissões provisórias. Esse poder permite que o partido estabeleça facilmente coligações eleitorais independente da posição ideológica do parceiro.

O que mais chama a atenção nesta análise é que, em geral, os partidos analisados são fortes. Eles são fortes porque detêm recursos essênciais para os políticos e porque esses recursos são controlados pelas lideranças por meio de mecanismos como os das comissões provisórias. Os partidos brasileiros são formados da base para a cúpula, mas a cúpula pode a qualquer momento dissolver a organização de base e remontá-la de modo a lhe beneficiar.

Diretório Nacional seria mais favorável para Aécio uma maior participação dos Diretórios Regionais traria maior probabilidade de vitória. 
Quando o senador Sérgio Machado propõe medidas para acabar com a "fragilidade da vida partidária" e para "fortalecer os partidos" ele está mirando no alvo errado. A vida partidária não é frágil e as lideranças detêm muito poder. O problema é que o senador e diversos analistas e cientistas políticos almejam um modelo partidário que só existiu em uma dada época e em alguns países, deixando de olhar de perto para os partidos brasileiros. 


\section{CAPÍTULO 6 - CONCLUSÃO}

O presente estudo ao ressaltar alguns aspectos pouco conhecidos da arena eleitoral permite entender melhor seu funcionamento. As eleições começam no interior do partido nas disputas pelo controle da organização partidária e pela definição das estratégias eleitorais. Em alguns partidos esta disputa é mais ferrenha, em outros o domínio das lideranças que formaram o partido é inconteste.

Vimos, examinando o número de candidatos em uma disputa, que a coordenação préeleitoral é a regra nas eleições majoritárias. Vimos também que o grau de controle das lideranças sobre a organização partidária tem impacto direto na coordenação eleitoral. Partidos onde o poder é pouco concentrado tendem a entrar mais em disputas eleitorais do que partidos com o controle concentrado. Por simetria, partidos com poder mais concentrado estabelecem mais coordenação eleitoral.

Um sistema majoritário onde há coordenação eleitoral é, em geral, mais representativo que sistemas majoritários onde ela não ocorre. Nas palavras de Cox:

If non-Duvergerian results crop up at various levels, however, then a strong electoral system can perform quite erratically. If the center fails to coordinate properly, relatively extreme candidates can win in the constituencies, and a party composed of such extremists can pull national policy fairly far from the national median. (COX, 1997:237) 
Assim os processos pelo qual os partidos coordenam, que, por sua vez, dependem dos processos pelos quais as lideranças ganham poder sobre as decisões estratégicas desses partidos, são essenciais para que se possa concluir se um sistema é mais ou menos representativo. Esses processos foram, em geral, ignorados pela literatura corrente.

A partir de nossos resultados como poderíamos caracterizar a arena eleitoral brasileira no que diz respeito às eleições majoritárias? Tipicamente podemos esperar que nas eleições para prefeito tenhamos menos de três partidos na disputa e nas eleições para governador e presidente tenhamos menos de quatro partidos efetivos. Quando isso não ocorre o eleitor irá votar estrategicamente e a diferença do segundo colocado para o terceiro, no caso da eleição municipal, ou do terceiro para o quarto, no caso das eleições de dois turnos, será muito grande. A vítima do voto estratégico será quase sempre o partido que não tinha chances de vitória e mesmo assim entrou na disputa, este partido provavelmente é um partido onde o controle sobre as decisões estratégicas é descentralizado.

Nossos resultados também mostram que os partidos que a literatura corrente trata como fracos, isto é, onde as lideranças não teriam controle sobre a organização e seus membros, são na verdade partidos fortes, daí o título desta tese. Deste modo, propostas de reformas que visam o fortalecimento partidário ou diminuir o número de partidos em disputa são inócuas.

Por um lado são inócuas porque nas eleições majoritárias o número de candidatos nas disputas é quase sempre pequeno, quase sempre há coordenação eleitoral e, portanto, maior estabilidade e representatividade. Por outro lado são inócuas porque, como mostram inúmeros trabalhos desde a contribuição de Figueiredo e Limongi (1995), há coordenação 
na arena decisória o que torna o sistema estável mesmo com eleições legislativas sob o sistema de representação proporcional.

As atuais propostas de reforma política, ao combater a representação proporcional, levariam a um enfraquecimento da representatividade do sistema político como um todo, se pensarmos a representatividade como a correspondência entre a opinião do eleitorado e a opinião dos seus representantes. E não haveria nenhum ganho que pudesse compensar esta perda.

De um ponto de vista positivo este trabalho adotou a sugestão de Panebianco (2005) para o qual o grau de centralização do processo decisório deve ser considerado uma variável independente nas análises institucionalistas. Ao procurar caracterizar como se dá o processo decisório no interior dos partidos trouxemos à luz dados pouco conhecidos sobre a organização partidária. Também revelamos dados pouco estudados sobre a configuração das disputas eleitorais municipais e estaduais no período recente. Por fim, testamos algumas teorias sobre coordenação eleitoral que, embora muito discutidas por estudiosos em outros países, mereceu pouca atenção de estudiosos brasileiros.

O sistema partidário merece ser examinado com mais cuidado e menos preconceito. Este exame pode revelar aspectos surpreendentes. 
ANEXO 1 - Distribuição dos partidos conforme situação do órgão partidário municipal por estado

\begin{tabular}{|c|c|c|c|c|c|c|c|c|}
\hline & & PP & PMDB & PT & PTB & PDT & PSDB & DEM \\
\hline \multirow[t]{3}{*}{$A C$} & Municípios & 22 & 16 & 20 & & & 13 & 21 \\
\hline & $\mathrm{CP}$ & 22 & 7 & & & & 10 & 21 \\
\hline & DIR & & 9 & 20 & & & 3 & \\
\hline \multirow[t]{3}{*}{$A P$} & Municípios & 15 & 14 & 16 & 12 & 16 & 8 & 13 \\
\hline & $\mathrm{CP}$ & 12 & 2 & 1 & 10 & 5 & 4 & 12 \\
\hline & DIR & 3 & 12 & 15 & 2 & 11 & 4 & 1 \\
\hline \multirow[t]{3}{*}{ DF } & Municípios & 1 & 1 & 1 & 1 & 1 & 1 & 1 \\
\hline & $\mathrm{CP}$ & & & & & 1 & & \\
\hline & DIR & 1 & 1 & 1 & 1 & & 1 & 1 \\
\hline \multirow[t]{3}{*}{ MG } & Municípios & 678 & 848 & 798 & 797 & 626 & 837 & 835 \\
\hline & $\mathrm{CP}$ & 678 & 316 & 51 & 638 & 428 & 389 & 332 \\
\hline & DIR & & 532 & 747 & 159 & 198 & 448 & 503 \\
\hline \multirow[t]{3}{*}{ MS } & Municípios & 69 & 78 & 78 & 78 & 78 & 78 & 75 \\
\hline & $\mathrm{CP}$ & 48 & 5 & 3 & 54 & 20 & 24 & 51 \\
\hline & DIR & 21 & 73 & 75 & 24 & 58 & 54 & 24 \\
\hline \multirow[t]{3}{*}{$\mathrm{PE}$} & Municípios & 131 & 143 & 175 & 181 & 144 & 147 & 147 \\
\hline & $\mathrm{CP}$ & 131 & 100 & 29 & 138 & 142 & 120 & 126 \\
\hline & DIR & & 43 & 146 & 43 & 2 & 27 & 21 \\
\hline \multirow[t]{3}{*}{ RJ } & Municípios & 92 & 92 & 92 & 92 & 92 & 92 & 91 \\
\hline & $\mathrm{CP}$ & 67 & 21 & 12 & 90 & 73 & 13 & 79 \\
\hline & DIR & 25 & 71 & 80 & 2 & 19 & 79 & 12 \\
\hline \multirow[t]{3}{*}{ RO } & Municípios & 48 & 51 & 51 & 52 & 47 & 56 & 52 \\
\hline & $\mathrm{CP}$ & 31 & 13 & 6 & 41 & 30 & 38 & 51 \\
\hline & DIR & 17 & 38 & 45 & 11 & 17 & 18 & 1 \\
\hline \multirow[t]{3}{*}{ RS } & Municípios & 495 & 492 & 483 & 486 & 487 & 380 & 296 \\
\hline & $\mathrm{CP}$ & 27 & 12 & 108 & 481 & 54 & 66 & 203 \\
\hline & DIR & 468 & 480 & 375 & 5 & 433 & 314 & 93 \\
\hline \multirow[t]{3}{*}{$\mathrm{RR}$} & Municípios & 14 & 15 & 15 & 11 & 15 & 15 & 14 \\
\hline & $\mathrm{CP}$ & 14 & 15 & 5 & 11 & 15 & 10 & 9 \\
\hline & DIR & & & 10 & & & 5 & 5 \\
\hline \multirow[t]{3}{*}{ SC } & Municípios & 293 & 293 & 287 & 195 & 263 & 299 & 293 \\
\hline & $\mathrm{CP}$ & 57 & 4 & 70 & 193 & 172 & 18 & 78 \\
\hline & DIR & 236 & 289 & 217 & 2 & 91 & 271 & 215 \\
\hline \multirow[t]{3}{*}{$\mathrm{SP}$} & Municípios & 505 & 632 & 635 & 645 & 531 & 645 & 641 \\
\hline & $\mathrm{CP}$ & 360 & 52 & 230 & 645 & 384 & 147 & 641 \\
\hline & DIR & 145 & 580 & 405 & & 147 & 498 & \\
\hline
\end{tabular}


ANEXO 2 - Distribuição dos partidos conforme situação do órgão partidário regional por estado

\begin{tabular}{llllllll} 
& PP & PMDB & PT & PTB & PDT & PSDB & DEM \\
\hline AC & DIR & DIR & DIR & & & DIR & CP \\
AM & CP & DIR & DIR & CP & CP & DIR & CP \\
AL & CP & DIR & DIR & DIR & DIR & DIR & CP \\
AP & & DIR & DIR & & DIR & DIR & CP \\
BA & DIR & DIR & DIR & CP & CP & DIR & DIR \\
CE & DIR & DIR & DIR & CP & DIR & DIR & DIR \\
DF & DIR & DIR & DIR & DIR & CP & DIR & DIR \\
GO & DIR & DIR & DIR & CP & DIR & DIR & DIR \\
MG & CP & DIR & DIR & CP & DIR & DIR & DIR \\
MS & DIR & DIR & DIR & CP & DIR & DIR & DIR \\
PA & DIR & DIR & DIR & CP & DIR & DIR & DIR \\
PE & CP & DIR & DIR & CP & CP & DIR & DIR \\
PI & DIR & DIR & DIR & CP & CP & DIR & CP \\
RJ & DIR & DIR & DIR & DIR & DIR & DIR & CP \\
RN & DIR & DIR & DIR & DIR & DIR & DIR & DIR \\
RO & DIR & DIR & DIR & CP & CP & DIR & CP \\
RS & DIR & DIR & DIR & CP & DIR & DIR & DIR \\
RR & CP & DIR & DIR & CP & DIR & DIR & CP \\
SC & DIR & DIR & DIR & CP & CP & DIR & DIR \\
SP & DIR & DIR & DIR & CP & CP & DIR & CP \\
TO & DIR & DIR & DIR & DIR & CP & DIR & DIR \\
\hline \hline & & & & & & & \\
\hline
\end{tabular}




\section{ANEXO 3 - Lista de siglas partidárias}

DEM - Democratas

PC do B - Partido Comunista do Brasil

PDS - Partido Democrata Social

PDT - Partido Democrático Trabalhista

PFL - Partido da Frente Liberal

PHS - Partido Humanista da Solidariedade

$\mathrm{PL}$ - Partido Liberal

PMDB - Partido do Movimento Democrático Brasileiro

PMN - Partido da Mobilização Nacional

PP - Partido Popular (antigo Partido Popular Brasileiro)

PPS - Partido Popular Socialista

PRTB - Partido Renovador Trabalhista Brasileiro

PSB - Partido Socialista Brasileiro

PSC - Partido Social Cristão

PSD - Partido Social Democrático

PSDB - Partido da Social Democracia Brasileira

PSDC - Partido Social Democrata Cristão

PSL - Partido do Solidarismo Libertador

PST - Partido Social Trabalhista

PSTB - Partido Social Trabalhista Brasileiro

PSTU - Partido Socialista dos Trabalhadores Unificado

PT - Partido dos Trabalhadores

PTB - Partido Trabalhista Brasileiro

PTN - Partido Trabalhista Nacional

PV - Partido Verde 


\section{BIBLIOGRAFIA}

ALDRICH, John H. Why Parties? The Origin and Transformation of Party Politics in America. Chicago: University of Chicago Press, 1995

AMES, Barry. Electoral Strategy under Open-List Proportional Representation. American Journal of Political Science, Vol. 39, No. 2, pp. 406-33, 1995.

AMES, Barry. The Deadlock of Democracy in Brazil. Ann Arbor: University of Michigan Press, 2001

AMORIN NETO, Octavio e SANTOS, Fabiano. A Conexão Presidencial: Facções Pró e Antigoverno e Disciplina Partidária no Brasil. Dados, vol. 44, n. ${ }^{\circ}$ 2, pp. 363-403, 2001.

AZEVEDO, Clóvis Bueno de. A Estrela Partida ao Meio, Ambiguidades do

Pensamento Petista. Livraria e Editora Entrelinhas, São Paulo, 1995.

BLONDEL, Jean. Party Systems and Pattern of Government in Western Democracies in CHARLOT, Jean Os Partidos Políticos, Brasília: Editora Universidade de Brasília, 1982.

CAIN, Bruce; FEREJOHN, John; FIORINA, Morris. The Personal Vote - Constituency Service and Electoral Independence. Cambridge, Massachusetts e Londres: Harvard University Press, 1987

CAREY, John M. e SHUGART, Matthew Sobberg. Incentives to Cultivate a Personal Vote: a Rank Ordering of Electoral Formulas. Electoral Studies, Vol. 14, No. 4, pp. 417439, 1995.

CATANHEDE, Eliane. PFL, Coleção Folha Explica, Folha de São Paulo, São Paulo, 2001

COX, Gary W. Electoral Rules and Electoral Coordination. Annual Review of Political Science 2: 145-61, 1999.

COX, Gary W. Making Votes Count - Strategic Coordination in the World's Electoral Systems, Cambridge, Cambridge University Press, 1997.

CROZIER, Michel, HUNTINGTON, Samuel et WATANUKI, Joji, The Crisis of Democracy: Report on the Governability of Democracies to the Trilateral Commission, ed. New York University Press, 1975.

CROZIER, Michel. ; FRIEDBERG, Erhard. L'acteur et le systéme. Paris: Èditions du Seuil,1977. 
DOWNS, Anthony. Uma teoria econômica da democracia. São Paulo: Edusp, 1999.

DUVERGER, Maurice. Os Partidos Políticos, São Paulo: Zahar, 1970.

FEDDERSEN, T., SENED, I e WRIGHT, S. Sophisticated Voting and Candidate Entry under Plurality Rule. American Journal of Political Science 34, 1990.

FEY, Mark. Stability and Coordination in Duverger's Law: A Formal Model of Preelection Polls and Strategic Voting. American Political Science Review, 91:135-147, 1997.

FIGUEIREDO, Argelina Cheibub e LIMONGI, Fernando. Incentivos Eleitorais, Partidos e Política Orçamentária. Dados, Vol. 45, No. 2, pp. 303-44, 2002

GOLDER, Matt. An Evolutionary Approach to Party System Stability. New York University: Unpublished manuscript, 2004.

GREENBERG, Joseph e SHEPSLE, Kenneth. The Effect of Electoral Rewards in Multiparty Competition with Entry. American Political Science Review 81:525-538, 1987.

HOPKIN, Jonathan. The Emergence and Convergence of the Cartel Party: Parties, State and Economy in Southern Europe Paper prepared for panel on 'The New Political Economy of European Political Parties' at the Conference of Europeanists, Chicago, 14-16 March 2002

IMAI, Kosuke, KING, Gary, e LAU, Olivia. 2008. logit: Logistic Regression for Dichotomous Dependent Variables in IMAI, Kosuke, KING, Gary, e LAU, Olivia, Zelig: Everyone's Statistical Software. http://gking.harvard.edu/zelig.

JONES, Mark P. e MAINWARING, Scott. The Nationalization of Parties and Party Systems an Empirical Measure and an Application to the Americas. Party Politics. Vol 9. No.2 pp. 139-166, 2003.

KATZ, Richard S. e MAIR, Peter. Changing Models of Party Organization and Party Democracy: The Emergence of the Cartel Party, Party Politics 1: 5-28, 1995.

KATZ, Richard S. The Problem of Candidate Selection and Models of Party Democracy. Political Studies, Vol. 7. No.3 pp. 277-296, 2001.

KINZO, Maria D’Alva Gil Partido. Eleições e Democracia no Brasil Pós-1985. Revista Brasileira de Ciências Sociais, Vol. 19, n. 54, fevereiro de 2004. 
KINZO, Maria D’Alva Gil. , BORIN, Ivan e MARTINS Jr., José Paulo. Padrões de Competição Eleitoral na Disputa para a Câmara Paulistana 1992-2000. Novos Estudos, N. 65, pp. 45-56, março de 2003.

KINZO, Maria D’Alva Gil. Oposição e Autoritarismo - Gênese e Trajetória do MDB (1966-1079). São Paulo: Vértice, Editora dos Tribunais, 1988.

KINZO, Maria D’Alva Gil. Radiografia do Quadro Partidário Brasileiro. São Paulo: Fundação Konrad-Adenauer, 1993.

KOLLMAN, Ken, MILLER, John e PAGE, Scott. Adaptive parties in spatial elections, American Political Science Review, vol. 86, No. 4,1992.

LAVER, Michael e SCHILPEROORD, M. Spatial models of political competition with endogenous political parties. Philosophical transactions of the Royal Society of London. Series B, Biological sciences. 362(1485):1711-21, 2007.

LEÃO, Elisabeth Ney Do MDB ao PMDB disponível em www.pmdb.org.br, último acesso em 08/05/2009.

LIMA Jr (org.). O Sistema Partidário Brasileiro. Rio de Janeiro: Editora Fundação Getúlio Vargas, 1997.

LIMA Jr. Partidos políticos brasileiros. A experiência federal e regional: 1945/64. Rio de Janeiro: Graal, 1983.

LIMA Jr. Partidos, Eleições e Poder Legislativo in Miceli, Sergio (org.) O que ler na ciência social brasileira (1970-1995). São Paulo: Editora Sumaré, 1999.

LIMONGI, Fernando e FIGUEIREDO, Argelina Cheibub. Partidos Políticos na Câmara dos Deputados: 1989-1994. Dados, Vol.38, n. ${ }^{\circ} 3,1995$

LIMONGI, Fernando. Formas de Governo, Leis Partidárias e Processo Decisório. In BIB, São Paulo, semestre 1, n. 55, p. 7-39, 2003.

LIMONGI, Fernando. Institucionalização Política in Miceli, Sergio (org.) O que ler na ciência social brasileira (1970-1995). São Paulo: Editora Sumaré, 1999.

MAINWARING, Scott \& SCULLY, T. R. (eds). Building Democratic Institutions Party Systems in Latin America. Stanford: Stanford University Press, 1995.

MAINWARING, Scott. Políticos. Partidos e Sistemas Eleitorais - O Brasil numa Perspectiva Comparada. Novos Estudos, No. 29, março de 1991. 
MAINWARING, Scott. Rethinking Party Systems in the Third Wave of

Democratization - The Case of Brazil. Stanford: Stanford University Press, 1999.

MAIR, Peter e KATZ, Richard. How Parties Organize. Cambridge, Cambridge University Press, 1990.

MAIR, Peter Party System Change, Approaches and Interpretations. Oxford:

Clarendon Press, 1997.

MARQUES, Eduardo César. Estado e Redes Sociais: Permeabilidade e Coesão nas

Políticas Urbanas no Rio de Janeiro. Rio de Janeiro: Revan, 2000.

MARQUES, Jales Ramos e FLEISCHER, David Verge. PSDB: de Facção a Partido. Brasília: Instituto Teotônio Vilela, 1999.

MAYHEW, David R. Congress, the Electoral Connection. New Haven e Londres: Yale University Press, 1974.

MELHEM, Célia Soibelmann. Política de Botinas Amarelas - O MDB-PMDB paulista de 1965 a 1988: Hucitec, São Paulo, 1998.

MENEGUELLO, Raquel. PT- A Formação de Um Partido (1979-1982). São Paulo: Paz \& Terra, 1989.

MICHELS, Robert. Political Parties. Glencoe: Free Press, 1962.

MOENIUS, Joannes e KASUYA, Yuko Measuring. Party Linkage Across Districts - Some Party System Inflation Indices and their Properties. PARTY POLITICS, Vol. 10, No. 5, pp. 543-564, 2004.

NICOLAU, Jairo. Disciplina Partidária e Base Parlamentar na Câmara dos Deputados no Primeiro Governo Fernando Henrique Cardoso (1995-1998). Dados, vol. 43, n. ${ }^{\circ}$ 4, pp. 709-735, 2000.

NICOLAU, Jairo Marconi ; SCHMITT, Rogério . Sistema eleitoral e sistema partidário. Lua Nova, São Paulo, v. 36, p. 129-147, 1995.

NIEMI, Richard G. e HSIEH, John Fuh-Sheng. Counting Candidates: An Alternative to the Effective $N$ (With an Application to the $M+1$ Rule in Japan). Party Politics, Vol. 8, No.1 pp. 75-99, 2002.

OSBORNE, Martin e SLIVINSKI, Al. A Model of Political Competition with CitizenCandidates. Quarterly Journal of Economics, 111:65-96, 1996. 
PALFREY, Thomas. Spatial Equilibrium with Entry. Review of Economic Studies 51:139 156, 1984.

PANEBIANCO, Ângelo. Modelos de Partidos: Organização e poder nos partidos políticos. São Paulo: Martins Fontes, 2005.

PEREIRA, Carlos e MUELLER, Bernardo. Comportamento Estratégico em

Presidencialismo de Coalizão: As relações entre Executivo e Legislativo na Elaboração do Orçamento Brasileiro. Dados, vol. 45, n. ${ }^{\circ}$ 2, pp. 265-301, 2002.

PEREIRA, Carlos e RENNÓ, Lucio. O que É que o Reeleito Tem? Dinâmicas PolíticoInstitucionais Locais e Nacionais nas Eleições de 1998 para a Câmara dos Deputados.

Dados, vol. 44, n. ${ }^{\circ}$ 2, pp. 323-362, 2001.

PERES, Paulo Sérgio. O Espectro da Instabilidade - Sistema Partidário e Volatilidade Eleitoral no Brasil Democrático. Dissertação de Mestrado, Departamento de Ciência Política da Faculdade de Filosofia Letras e Ciências Humanas, 1999.

POWER, Thimoty e ZUCCO Jr, Cesar. Estimating Ideology of Brazilian Legislative Parties, 1990 - 2005: A Research Communication. Latin American Research Review, 2008.

PULS, Mauricio. O Malufismo. São Paulo: Publifolha, 2000.

RAHAT, Gideon e HAZAN, Reuven Y. Candidate Selection Methods an Analytical framework. Political Studies, Vol. 7. No.3 pp. 297-322, 2001.

RIKER, William H. Duverger`s Law Revisited in GOFMAN, Bernard e LIJPHART, Arend. Electoral Laws and Their Political Consequences. New York: Aghaton Press, 1986.

RODRIGUES, Leôncio Martins. Partidos Ideologia e Composição Social - Um Estudo das Bancadas Partidárias na Câmara dos Deputados. São Paulo: EDUSP, 2002.

ROKKAN, Stein. The Growth and Structuring of Mass Politics in Smaller European Democracies, citado in MAIR, Peter Party System Change, Approaches and Interpretations. Oxford: Clarendon Press, 1997.

ROMA, Celso (1999) A Social Democracia no Brasil: Organização, Participação no Governo e Desempenho Eleitoral do PSDB (1988-1998). Dissertação de Mestrado, Departamento de Ciência Política da Faculdade de Filosofia Letras e Ciências Humanas, 1999. 
SAMUELS, David. Determinantes do Voto Partidário em Sistemas Eleitorais Centrados no Candidato: Evidências sobre o Brasil. Dados, vol. 40 no. 3 Rio de Janeiro 1997.

SANTOS, André Marenco. Sedimentação de Lealdades Partidárias no Brasil: Tendências e Descompassos. Revista Brasileira de Ciências Sociais, vol. 16, n. ${ }^{\circ}$ 45, pp. 69-84, 2001.

SARTORI, Giovanni. Partidos e Sistemas Partidários. Tradução Waltensir Dutra, ed. Brasileira rev. ampl., RJ, Zahar, Brasília, UNB, 1982.

SARTORI, Giovanni. The Influence of Electoral Systems: Faulty Laws or Faulty Method? In GOFMAN, Bernard e LIJPHART, Arend. Electoral Laws and Their Political Consequences. New York: Aghaton Press, 1986.

SCHATSHNEIDER, E. E. Party Government: American Government in Action. New York: Farrar and Rinehart, Inc., 1942.

SCHMITT, R.; CARNEIRO, L. P. e KUSCHNIR, K. Estratégias de Campanha no Horário Gratuito de Propaganda Eleitoral em Eleições Proporcionais. Dados, vol. 42, no 2, pp. 277 297, 1999.

SEILER, Daniel-Louis. Os Partidos Políticos. Brasília: Ed. Universidade de Brasília: São Paulo, Imprensa Oficial, 2000.

SENADO FEDERAL, Relatório Final da Comissão Especial destinada a estudar a Reforma Político-Partidária, Brasília, 1998.

SHEFTER, Martin. Party and Patronage: Germany, England and Italy. Politics and Society, Vol. 7, No. 4. 1977.

SHEFTER, Martin. Regional Receptivity to Reform: The Legacy of the Progressive Era. Political Science Quarterly, Vol. 98, No. 3, fall 1983.

SORES, Gláucio Ary Dillon. A democracia interrompida. Rio de Janeiro: Editora Fundação Getúlio Vargas, 2001.

SOUZA, Maria do Carmo Campello de. Estado e Partido Políticos no Brasil (1930 a 1964). São Paulo: Alfa-Omega, 1976.

TSEBELIS, George. Jogos Ocultos. EDUSP: São Paulo, 1998.

WEBER, Shlomo. Entry Deterrence in Electoral Spatial Competition. Social Choice and Welfare, 15:31-56, 1998.

WEBER, Shlomo. On Hierarchical Spatial Competition. The Review of Economic Studies 59:407-425, 1992. 